\author{
By \\ Sharmeen Niger \\ Bachelor of Architecture, Ahsanullah University of Science \& Technology, 2006 \\ Master of Planning and Design, University of Melbourne, 2010
}

\author{
A Major Research Project \\ presented to Ryerson University \\ in partial fulfillment of the requirements \\ for the degree of Master of Building Science \\ in the Program of Building Science
}

Toronto, Ontario, Canada, 2016

(C) Sharmeen Niger 2016 
Author's Declaration Page

I hereby declare that I am the sole author of this MRP. This is a true copy of the MRP, including any required final revisions.

I authorize Ryerson University to lend this MRP to other institutions or individuals for the purpose of scholarly research

I further authorize Ryerson University to reproduce this MRP by photocopying or by other means, in total or in part, at the request of other institutions or individuals for the purpose of scholarly research.

I understand that my MRP may be made electronically available to the public. 


\title{
HIGH PERFORMANCE RETROFIT OPPORTUNITIES OF TORONTO'S 1970 S RESIDENTIAL DETACHED AND SEMI-DETACHED HOUSES
}

\author{
By \\ Sharmeen Niger \\ Master of Building Science, 2016 \\ Ryerson University
}

\begin{abstract}
Based on previous studies of Toronto's residential archetypes, this research focuses on retrofit opportunities of 1970s OBC (Ontario Building Code) detached and semi-detached houses in order to understand its viability at the micro level. A GIS mapping has been utilized to identify the concentrations of 1970s OBC archetype in old Toronto area. A comprehensive field survey has been performed to collect data for creating a baseline model which also establish a consistent characteristic of 1970s OBC archetype. The EnergyPlus baseline model is then validated by calibration method to finalize the baseline model for an in depth retrofit analysis. The energy simulation has been performed to identify the most attractive combination of retrofit opportunities for highest cost/benefit. The research illustrates that meeting the target of 75 $\mathrm{kWh} / \mathrm{m}^{2}$ for $1970 \mathrm{~s}$ OBC detached and semi-detached houses is not always possible with attractive cost-effective options because of their differences in geometric shape and envelope system.
\end{abstract}




\section{Acknowledgment}

First and foremost, I would like to acknowledge the inspirational instruction and guidance of my research supervisor Dr. Miljana Horvat. As a professor her enormous support, precise suggestions and direction helped me to complete the master's degree.

I also like to express my gratitude to Russell Richman as my second reader whose works and research papers helped me to guide my research methodology

I also like to thank Denver Jermyn for his support and inspiration to work with the topic which is a continuation of his thesis work and laid the foundation for this research.

I would like to thank Charles Riddell, Matt Carlsson and all other classmates for their meaningful comments and advices during the research work. I am grateful to all research participants who helped to conduct the research survey successfully.

Last but not least; I want to thank my family, whose continuous support helped me to accomplish this educational achievement. 


\section{Table of Contents}

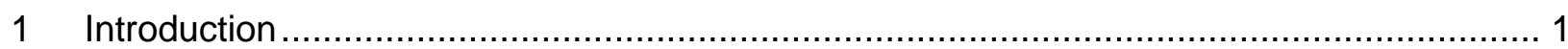

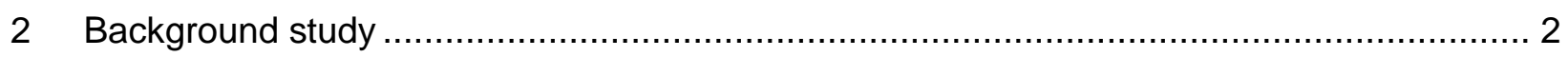

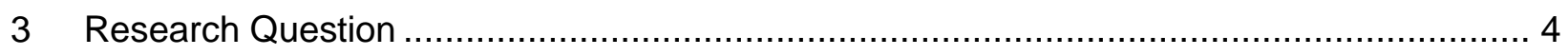

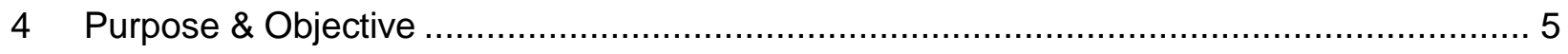

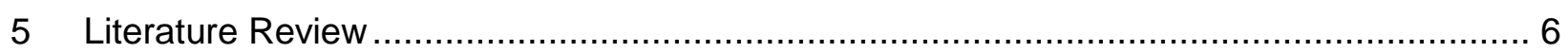

5.1 High density single family homes in Urban Toronto Neighbourhood ........................... 7

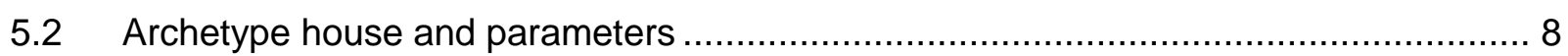

5.3 Toronto's 1970s OBC Archetype houses …………...........................................10

5.4 Energy Use in 70s OBC Archetype Houses .....................................................11

5.5 High Performance Buildings; Energy-Saving Retrofit Technologies to Reduce Energy

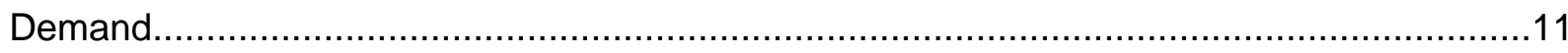

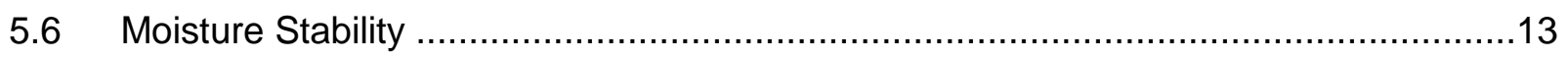

5.7 Energy Modeling for High Performance Retrofit ..................................................14

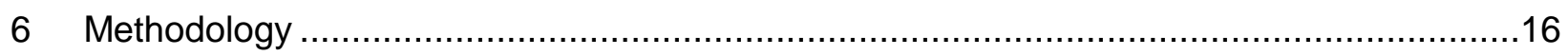

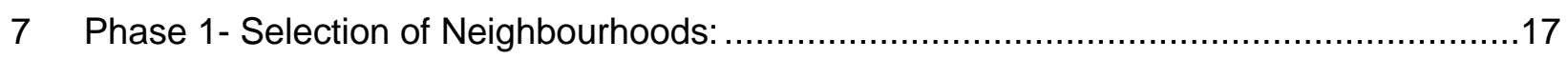

7.1 GIS Mapping for 1970s OBC Archetype House \& Neighbourhood Selection...............19

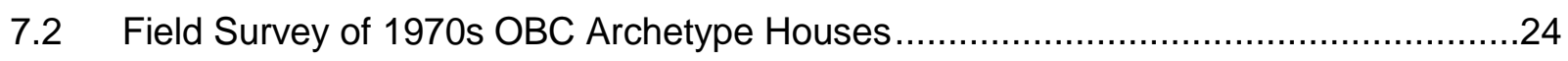

8 Phase 2- Data collection for Baseline Energy Modelling: ..............................................28

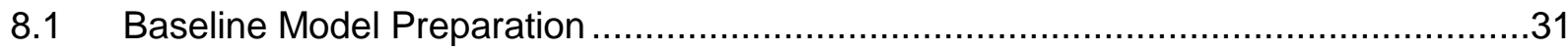

8.1.1 Infiltration Model ..................................................................................

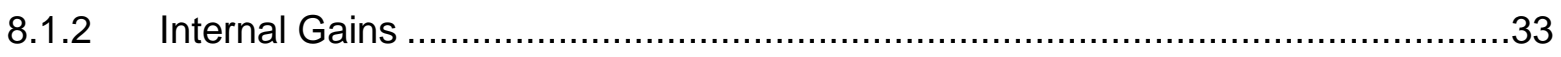

8.1.3 Interzone Openings \& Envelope Framing Factors …….....................................35

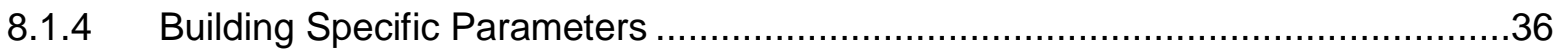


8.1.5 1970s OBC Single Detached House Baseline Model and Validation.

8.1.6 1970s OBC Semi- Detached House Baseline Model and Validation ..................42

8.2 Calibration of the Baseline Energy models ................................................44

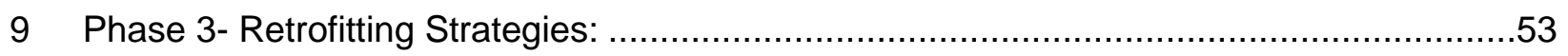

9.1 Energy performance \& Retrofitted Energy Model Result ...................................56

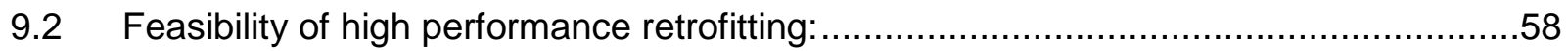

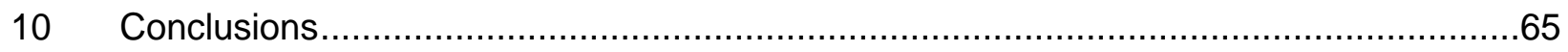

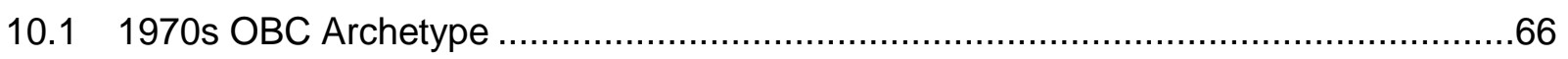

10.2 Baseline Model and Energy performance of 1970s Archetype .............................67

10.3 Energy Efficient Retrofit Impact \& Target Energy Intensity $75 \mathrm{kWh} / \mathrm{m}^{2}$..................67

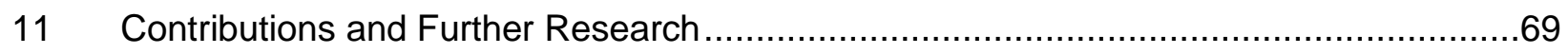

Appendix A: Number of Total Single Detached \& Semi-Detached Houses in Urban Toronto Neighbourhoods and Number of 70s OBC Archetypes within these neighbourhoods ..............72

Appendix B: Ryerson University Ethics Approval ...................................................... 74

Appendix C: Survey Questionnaire for Research Participants......................................75

Appendix D: Survey Data for 70s OBC Archetype Houses..........................................79

Appendix E: Energy Bill Data for 70s Single Detached \& Semi-Detached Houses ...................83

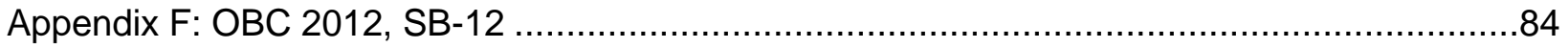

Appendix G: Retrofit options for 70s OBC Single detached and Semi-detached Houses ..........85

Appendix $\mathrm{H}$ : Condensation and Decay Hours for retrofit assemblies..............................

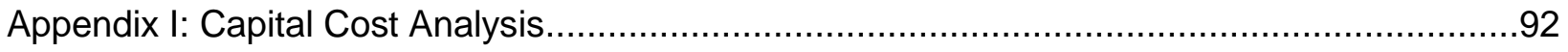

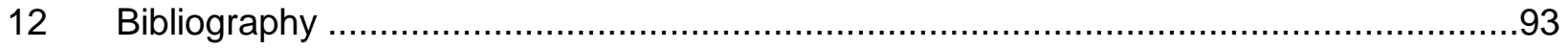




\section{List of Tables}

Table 1: Characteristics to Identify Archetypes (Adapted from Blaszak and Richman, 2013) ..... 9

Table 2: Summary Description of the Four Housing Archetypes .......................................10

Table 3: Selected Neighbourhoods for Single Detached Houses Survey \& Energy Intensity

Profile .24

Table 4: Selected Neighbourhoods for Semi-Detached Houses Survey \& Energy Intensity Profile

Table 5: The Most Common Features of Detached and Semi-Detached 1970s OBC Houses...27

Table 6: Number of Houses Surveyed in Selected Neighbourhoods ...................................28

Table 7: Parameters Selected for Data Collection and Energy Modeling ...............................29

Table 8: Building Specific Parameters for Baseline Model ...................................................37

Table 9: Summary of Baseline Model Result............................................................43

Table 10: 1970s OBC Detached House Energy Bill (2014) Normalization...........................47

Table 11: 1970s OBC Semi-Detached House Energy Bill (2014) Normalization.......................50

Table 12: Final Baseline Energy Use and Intensity of Archetype Houses for Heating and Cooling Load.

Table 13: Retrofitting Strategy for 1970s OBC Houses ..............................................54

Table 14: Retrofitting Guideline for Building Envelope System of 1970s OBC Houses.............54

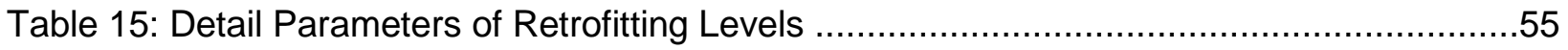

Table 16: High Performance Retrofit Result for 1970s Detached House ..............................57

Table 17: High Performance Retrofit Result for 1970s Semi-Detached House ........................58

Table 18: Average Areas of 1970s OBC Detached \& Semi-Detached House .........................59

Table 19: Retrofit Cost Analysis Considering Energy Intensity Savings for Individual Parameters

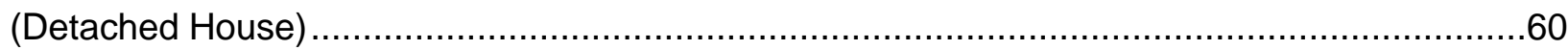

Table 20: Retrofit Cost Analysis Considering Energy Intensity Savings for individual Parameters (Semi-Detached House). 60 
Table 21: Brute Force Sequential Search Method to Identify the Most Cost Effective Combination of Retrofitting for 1970s OBC Detached Houses

Table 22: Brute Force Sequential Search Method to Identify the Most Cost Effective

Combination of Retrofitting for 1970s OBC Semi-Detached Houses.

Table 23: Minimum Retrofit Level to Meet the Retrofit Target for 1970s OBC Detached Houses

Table 24: Minimum Retrofit Level to Meet the Retrofit Target for 1970s OBC Semi-Detached Houses .64 


\section{List of Figures}

Figure 1: Concentration of Single Family Homes in Urban Toronto Neighbourhoods (Adapted from Blaszak, 2010)

Figure 2: Four Archetype Houses in Urban Toronto (Adapted from Blaszak \& Richman, 2013) . 9

Figure 3: 1970s Single Family Detached Houses in Clarington (NRCan-CanmetENERGY, 2009)

Figure 4: Sequential Method of Research .16

Figure 5: Density of All single-Detached Houses in Comparison with the Number of 1970s Single Detached Houses.

Figure 6: Density of all Semi-Detached Houses in Comparison with the Number of 1970s SemiDetached Houses 21

Figure 7: Density of 1970s Semi-Detached Houses in Comparison with the Energy Intensity ...21

Figure 8: Map Showing Selected Neighbourhoods for Field Survey ..... .23

Figure 9: City of Toronto Map of Individual Units/Lots by Construction Periods (Source: Toronto Achieves) .25

Figure 10: 1970s Archetype Characteristic Compared Between Blaszak (2010) and this Research Survey. .26

Figure 11: 1970s Archetype Categories Identified in the Field Survey .27

Figure 12: Floor Plans of 1970s OBC Archetype, Source: Collected from Research Participants

Figure 13: Conceptual Drawings Illustrates that the data are collected based on front, side and rear walls regardless there north orientation 32

Figure 14: Geometry of 1970s OBC Single Detached House Baseline Energy Model. 39

Figure 15: The Garage Space (Unheated Buffer Space) and Insulated Interzone Surfaces (Black Dots) and Garage Slab Incorporating to Reduce Heat Loss.

Figure 16: Geometry of 1970s OBC Semi-Detached House Baseline Energy Model .42

Figure 17: 1970s OBC Detached House Calibration: Energy Bill \& Energy Model (GJ)................ .46 
Figure 18: 1970s OBC Detached House Calibration: Normalized Energy Bill \& Energy Model (GJ).

Figure 19: 1970s OBC Detached House Calibration: Normalized Energy Bill \& Fine Tuned Energy Model (GJ)

Figure 20: 1970s OBC Semi-Detached House Calibration: Energy Bill \& Energy Model (GJ) ...50 Figure 21: 1970s OBC Semi-Detached House Calibration: Energy Bill \& Energy Model (GJ) ...51 Figure 22: 1970s OBC Semi-Detached House Calibration: Normalized Energy Bill \& Fine Tuned Energy Model (GJ) 52 


\section{Introduction}

Currently, the City of Toronto relies primarily on non-renewable energy sources (including natural gas which is $63 \%$ among all resources). While local renewable energy resources provide only $0.6 \%$ of the Toronto's overall energy production, the city's Sustainable Energy Plan envisions that by 2030 the contribution of local renewable energy will increase to $5 \%$ (The city of Toronto, 2007). However, according to Toronto's Sustainable Energy Plan, the city should also be able to reduce the total energy consumption by $21 \%$. The reduction of overall energy consumption through systematic and efficient energy use will play a major role in Toronto's long-term energy plan. Residential energy consumption (gas and electricity) accounts for $43 \%$ of the total energy consumed in Toronto (The City of Toronto, 2007). Existing research suggests that the reduction of energy consumption from residential intake could play significant role towards sustainability in the energy sector. Currently, $33.1 \%$ of private residential households in Toronto reside in single-detached and semi-detached houses (Statistics Canada, 2011). Single detached houses are one of the major sources of inefficient energy usage due to high per capita energy usage and high internal energy gain (Jermyn, 2014; Blaszak and Richman, 2013; Zirnhelt, 2013). In Canada, single-detached dwellings use 1.8 times more energy than apartment buildings on a per capita basis (Norman, McLean, \& Kennedy, 2006, cited from Jermyn, 2008). Most of the existing research on retrofitting focuses on single detached dwellings in poor condition built before 1970. Such units require extensive maintenance or retrofitting to upgrade overall energy efficiency. According to 2006 census data, $42 \%$ of all single-detached dwellings in Toronto were built after 1971 (Hulchanski, 2007). In contrast to the significant focus on older buildings, relatively newer buildings receive minimal attention regarding investigations of energy efficiency. Blaszak (2010) and Blaszak and Richman (2012) describe the post-1970s single-family housing stock as 1970 s OBC as part of four archetypes of Toronto housing history, and conduct comparative analysis between their construction 
techniques and energy performances. However, most of the existing literature overlooks analysis of retrofit opportunities pertaining to 1970 s single-family houses. This provides an opportunity to focus on these 1970s single-family houses to understand how they perform in terms of energy efficiency, and to investigate the viability of retrofitting to improve overall energy efficiency in the housing sector of the city. The principal objectives of this investigation are to define the potential and feasibility of retrofitting the 1970s OBC archetype (1971-1980), and to contribute research that serves future high performance retrofitting investigations of Toronto's old housing stock.

\section{Background study}

There is a growing focus on retrofitting opportunities for old houses to improve overall energy efficiency. Evidence suggests that "energy-efficiency retrofits to existing buildings represent the biggest, fastest, cheapest, cleanest, and most long-lasting opportunity to reduce energy use and greenhouse gas emissions in cities" (Pitt, Randolph, St. Jean, and Chang, 2012). Therefore it is important to maximize retrofit opportunities and consider a wide range of archetypes characterized by higher intensity of energy consumption. A background study of this research identifies that existing literature on retrofit opportunities focuses mostly on older houses which are built between early and mid-twentieth century (so called Century and War-Time houses). There are very few research found that investigated houses between 1970s and 1980s. However, this time frame should be considered as an important phase of Toronto's housing sector as the province first inaugurated guidelines for thermal performance in the building code. This research attempts to extend the early research work of retrofitting possibilities to 1970 s residential houses to understand their characteristics, energy performance and retrofit needs.

To include 1970s OBC single detached and semi-detached houses for retrofitting opportunities, this research provides a background study that identifies potential archetypes covered by 
existing literature, analyses methodologies used to measure energy consumption characteristics, and finally establishes parameters for high performance retrofitting. From the literature review, two previous studies within the Toronto context have been adapted to prepare a methodology of archetype selection, data collection, base model preparation, and retrofit analysis of 1970s OBC single detached and semi-detached houses.

Blaszak and Richman (2013) \& Blaszak (2010) worked with four archetype houses which are Century, War-time, 1970s OBC and Modern houses. Archetypes were generated within 43 neighbourhoods of Old Toronto. To analyse the energy consumption of these archetypes, energy model analyses were conducted utilizing by HOT2000 software. Energy model data was collected from different sources, including the Canadian national database, and personal interviews. The target energy intensity for heating cooling load was $100 \mathrm{kWh} / \mathrm{m}^{2}$. To achieve this target, different building envelope retrofitting options were adopted for four archetype single detached houses.

Jermyn (2014) adapted Blaszak's work to establish a methodology associated with a more in depth investigation for Century (detached, semi-detached) and War-Time archetype house. While Blaszak relied on HOT2000 software, Jermyn used EnergyPlus for a more detailed analysis of the baseline model. His study investigated archetype houses of 23 neighbourhoods in old urban Toronto areas based on their energy intensity. The target of heating and cooling load was set to $75 \mathrm{kWh} / \mathrm{m}^{2}$ which is even more ambitious than Blaszak's work. This work included building survey to cross-check the collected data with Blaszak \& Richman (2013). The base case parameters were collected both from site survey and Blaszak's research (literature review). The energy performance was verified with EnergyPlus software. The energy model results were validated through a process of calibration with energy bills for all archetype houses. 
This research focuses on high performance retrofit for 1970s OBC (1971-1980) single detached and semi-detached houses within the same urban boundary as Jermyn (2014) studied as a continuity of his study. The target for heating and cooling load is also set for $75 \mathrm{kWh} / \mathrm{m}^{2}$ as used by Jermyn (2014). While the method of energy modeling for 1970 s OBC has been adopted from Jermyn (2014), this research differs from its precedent studies through a different approach of identifying samples from 43 neighbourhoods. The neighbourhoods are selected considering a combination of high density and high-energy intensity analysis using GIS (Geographic Information System) mapping. Another purpose of this approach is to re-investigate the basic character and parameters of 1970s single detached and semi-detached archetypes that are not comprehensively covered in any of the precedent studies through direct site survey.

\section{Research Question}

The research hypothesis inquires about the 1970s OBC archetype single-detached and semidetached houses (post-1970s houses) and argues that despite having improvement in building code and materials, 1970s houses continue to show relatively higher energy consumption. The research also claims that 1970 s OBC archetype represents specific characteristics not detailed in previous studies that need to be considered to get a comprehensive list of parameters including geometric and structural characteristics. By setting up a consistent and defined archetype will help to produce a more accurate baseline model and identify retrofit opportunities. Based on this hypothesis the research principally investigates the following research question:

What characteristics are associated with single and semi-detached houses to define 1970s OBC Archetype; what level of energy performance exists and how can a target energy intensity be achieved through retrofit opportunities? 
To establish a consistent characteristic and to analyse the energy consumption of 1970 s OBC archetype (residential single-detached and semi-detached houses), the following sub-questions are investigated:

1. What areas of the City of Toronto have the highest concentration of 1970s OBC Archetype (post-1970s) houses?

2. What characteristic data is required to produce a baseline energy model for the specific period of archetypes?

a. What are the geometric and structural characteristics?

b. What type of HVAC system is used in both cases?

c. What types of envelope system exists in these archetypes?

d. What other aspects of heat gain and loss need to be considered for baseline condition models?

e. What level of energy consumption is evident in 1970s houses from baseline conditions?

3. Considering $75 \mathrm{kWh} / \mathrm{m}^{2}$ as target energy intensity for heating and cooling (benchmark established from literature review), how are the performances of baseline condition model of each type of 1970 s OBC archetype?

a. How close are they to target energy consumption?

b. Is it viable to retrofit considering their performance?

\section{Purpose \& Objective}

The research has two overarching objectives. The first one is to understand the baseline condition of 1970s OBC archetype houses from the perspective of annual energy consumption, as this archetype has not been analysed in the previous studies. This will allow for a comparison of single-detached residential buildings from energy consumption point-of-view for 
1970s OBC archetype houses with data collected from existing literature of Blaszak and Richman (2013).

The second objective is to investigate the viability of high performance retrofitting for 1970s OBC archetype houses to improve energy efficiency based on the results of energy modelling. This will allow identifying whether deep retrofitting by incorporation of high performance building envelope and HVAC systems contribute to reduce energy consumption or not.

\section{$5 \quad$ Literature Review}

It was found that single-dwelling homes (low density) are more energy intensive than highdensity apartment buildings (VandeWeghe \& Kennedy, 2007). Energy use for building operation is the primary contributor for the whole energy intensity of these buildings. The age of the houses is an important factor because of their performance and building code changes and these changes affect the energy efficiency of a whole neighbourhood. This phenomenon has been investigated in the context of Toronto by several researchers, and has been reviewed, adapted, and extended in the background study in this research. From the exiting literature (Blasak, 2010; Jermyn. 2014) and through a series of field studies, it is evident that throughout the city's history, Toronto's residential houses have been developed according to four archetypes:

- Century homes

- War-Time Homes

- 1970s OBC Homes

- Modern homes

Specific building envelope characteristics are defined for each archetype by existing literatures. This literature review particularly focuses on 1970s OBC single detached and semi-detached 
houses and further investigated, compared and developed archetype characteristics. Existing literature of energy modeling approaches in the context of Toronto's archetypes are reviewed to identify and adapt specific parameters and methodologies. These parameters along with survey data helps to create a baseline model of this archetype houses.

\subsection{High density single family homes in Urban Toronto Neighbourhood}

Blaszak (2010) identified three major regions in the urban Old Toronto area by adapting data from Toronto Neighbourhood Profiles (City of Toronto, 2013) that are considered relatively old neighbourhoods and has significant blend of mix of housings. Figure 1 represents the map of the neighbourhood with total number of units within old Toronto. Among the three regions, the first one is located at the east of the City of Toronto between Riverdale and Beach and has greater than 2000 units per neighbourhood which includes all type of units including single detach, semi-detach, townhouse and apartment buildings. The second region is at west located at north and south of Bloor in the High Park and Parkdale area, which also has at least 2000 units per neighbourhood. Thirdly, at north region located along the eastern side of Yonge Street and north of Bloor Street which has also considerably higher number of units. These three regions have an average of more than 944 single detach and 697 semi-detach houses where as average 1970s OBC single detached and semi-detached houses are 96 and 64 (Appendix A) respectively. This research selected 1970s OBC single detached and semi-detached houses from all these three regions as an extension of Jermyn's (2104) research where he focused on Century and Wartime houses. The outcome of this research will provide an insight of viability of retrofit for 1970s OBC archetype as Jermyn did for Century and Wartime houses. 


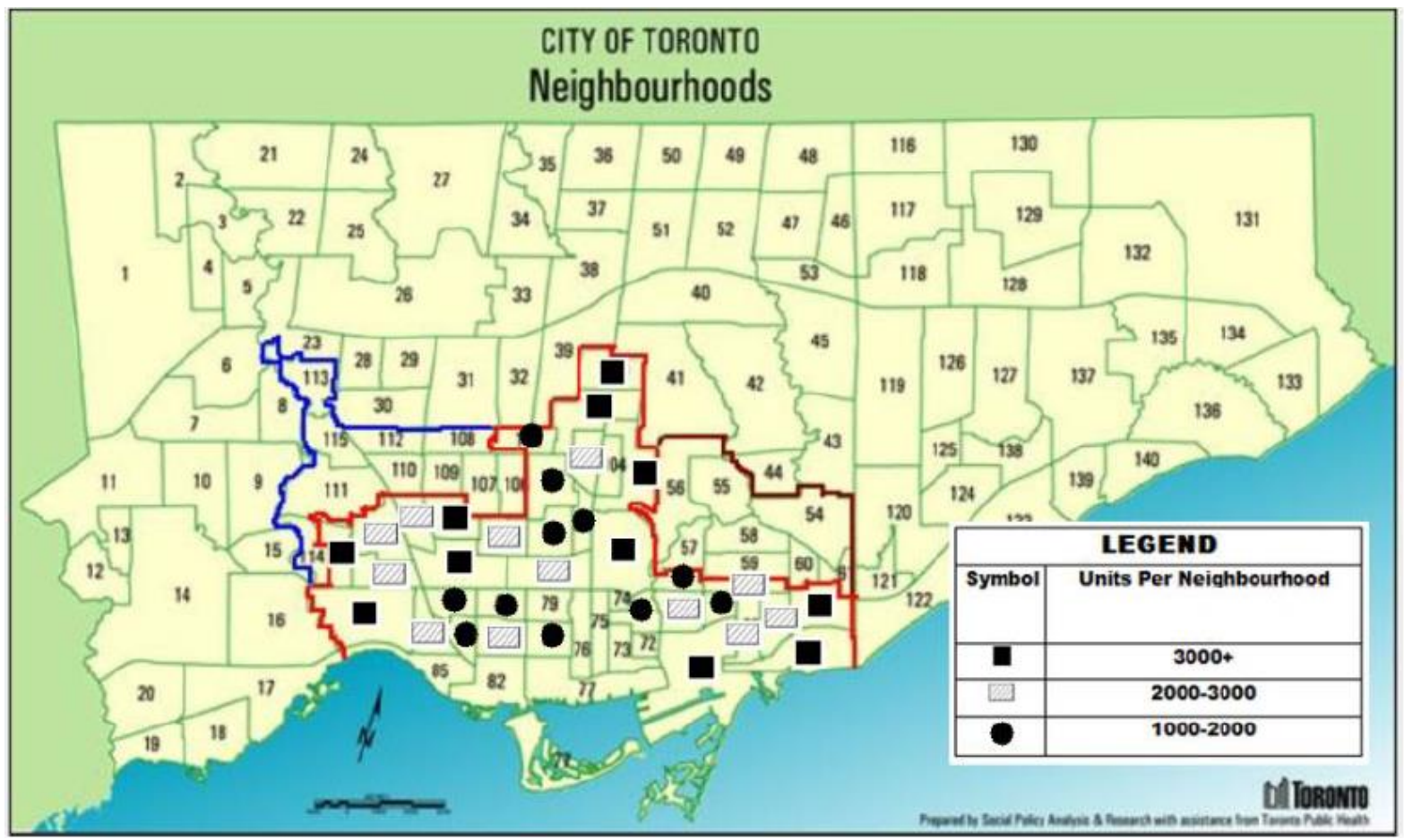

Figure 1: Concentration of Single Family Homes in Urban Toronto Neighbourhoods (Adapted from Blaszak, 2010)

\subsection{Archetype house and parameters}

Blaszak and Richman (2013) identified four housing archetypes for single family housing stock from historical study of the development in the higher density neighbourhoods of the identified regions of Old Toronto region. The physical characteristics of the identified archetypes are illustrated in Figure 2.

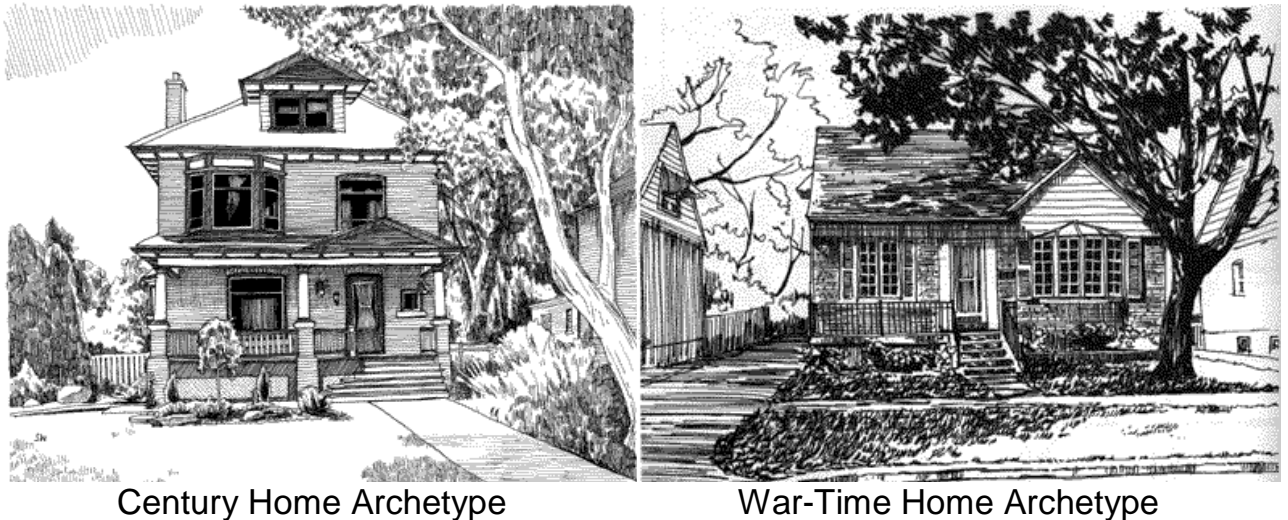




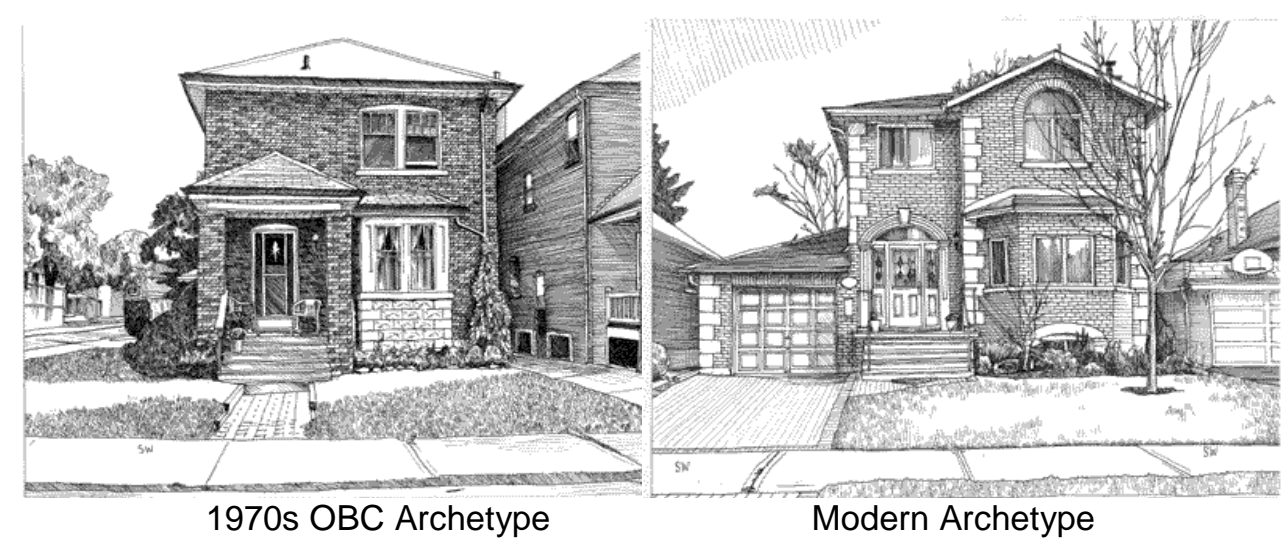

Figure 2: Four Archetype Houses in Urban Toronto (Adapted from Blaszak \& Richman, 2013)

These archetypes houses were identified with some specific characteristics and parameters which was developed by Blaszak and Richman (2013) and showed in table 1.

Table 1: Characteristics to Identify Archetypes (Adapted from Blaszak and Richman, 2013)

\begin{tabular}{|l|l|l|}
\hline Construction & Geometry & Vintage \\
\hline - $\begin{array}{l}\text { Structural design - load bearing masonry or } \\
\text { light wood-frame, foundation, } \\
\text { etc. }\end{array}$ & $\begin{array}{l}\text { Size - volume, heated } \\
\text { floor area, etc. } \\
\text { Shape - rectangular or } \\
\text { non-rectangular, } \\
\text { number of storeys, etc. }\end{array}$ & $\begin{array}{l}\text { Year, decade, or } \\
\text { period of } \\
\text { construction }\end{array}$ \\
$\begin{array}{l}\text { walls, ceiling, foundation, etc. } \\
\text { - Materials - cladding, types of insulation, etc. } \\
\text { glazing - amount, type, and orientation }\end{array}$ & & \\
\hline
\end{tabular}

Table 2 showing the detail features and insulation values for four archetype houses determined by Blaszak \& Richman (2013). 
Table 2: Summary Description of the Four Housing Archetypes

(Adapted from Blaszak \& Richman, 2013)

\begin{tabular}{|c|c|c|c|c|}
\hline Archetypes & Century & War Time & $70 \mathrm{~s}$ OBC & Modern \\
\hline Heated Floor Area & $208 m^{2}$ & $182 m^{2}$ & $216 m^{2}$ & $239 m^{2}$ \\
\hline \multicolumn{5}{|l|}{ Building } \\
\hline \# Storeys & 2.5 & 1 & 2 & 3 \\
\hline Plan Shape & L-shape & Rectangular & Rectangular & L-shape \\
\hline Vintage & $<1940$ & $1940-60$ & $1970 \mathrm{~s}$ & $>2000$ \\
\hline Lot Placement & $\begin{array}{l}\text { Adjacent to } \\
\text { Neighbours }\end{array}$ & Driveway on one side & $\begin{array}{l}\text { Adjacent to } \\
\text { Neighbours }\end{array}$ & $\begin{array}{l}\text { Adjacent to } \\
\text { Neighbours }\end{array}$ \\
\hline Features & $\begin{array}{l}\text { Finished attic, full- } \\
\text { width porch }\end{array}$ & Half-width porch & $\begin{array}{c}\text { Partly raised } \\
\text { basement, narrow } \\
\text { awning }\end{array}$ & $\begin{array}{c}\text { Attached garage, } \\
\text { narror porch }\end{array}$ \\
\hline Roof & Gable front, flat rear & Hip & Hip & Hip with gable accents \\
\hline Structure & Double-wythe brick & Light-wood frame & Light-wood frame & Light-wood frame \\
\hline Cladding & Brick & Brick & Brick & Brick \\
\hline \multicolumn{5}{|l|}{ Insulation (RSI) } \\
\hline \begin{tabular}{|l|l|} 
& Ceiling \\
\end{tabular} & 2.74 & 3.66 & 4.18 & 5.76 \\
\hline Walls & 1.11 & 1.41 & 1.71 & 5.9 \\
\hline Foundation & 0.52 & 0.74 & 1.16 & 2.01 \\
\hline Air Leakage (ACH) & 11.24 & 7.5 & 5.75 & 3.42 \\
\hline \multicolumn{5}{|l|}{ Glazing (\%) } \\
\hline Front & 20 & 20 & 20 & 15 \\
\hline Side & 3 & 8 & 5 & 3 \\
\hline Rear & 20 & 15 & 25 & 25 \\
\hline
\end{tabular}

\subsection{Toronto's 1970s OBC Archetype houses}

'The energy crisis' that occurred in the 1970s influenced the building industry to focus on insulating and sealing the building to prevent high energy consumption and increase energy efficiency. The homes built that time followed the Ontario Building Code $(\mathrm{OBC})$ published in that time period (1971-1980). The OBC was based on the National Building Code, and there were requirements of thermal performance of the house. However, the focus was given on limiting deterioration to the building and keeping the occupant comfortable rather than efficient use of resources (Blaszak, 2010). This is one of the reasons, it would be valuable to conduct a comprehensive investigation and energy analysis to understand the energy performance of 1970s OBC houses, and to understand their retrofit opportunities. 
The 1970s OBC archetype in most cases is a two-storey high rectangular house with a total heated floor area of $216 \mathrm{~m} 2$ according to the ecoENERGY database (Blaszak, 2010). The basement is full height and the foundation wall is mostly above grade and the basement windows are slightly larger (Blaszak, 2010).

\subsection{Energy Use in 70s OBC Archetype Houses}

CanmetENERGY, the part of Natural Resources Canada has done a study on energy consumption of urban archetypes residential houses across Canada and they investigated on eight communities. Among these communities, Ottawa and Clarington within Ontario have similar weather to Toronto. In Clarington, the single family detached houses built between 19611977, can have the overall energy intensity of $190 \mathrm{kWh} / \mathrm{m}^{2}\left(684 \mathrm{MJ} / \mathrm{m}^{2}\right)$ for single storey (figure 3, house type A) and $266 \mathrm{kWh} / \mathrm{m}^{2}\left(957 \mathrm{MJ} / \mathrm{m}^{2}\right)$ for two storey houses (figure 3 , house type C) (NRCan - CanmetENERGY, 2009). It is estimated that the energy intensity should be similar for 1970s OBC detached houses in Toronto climate.
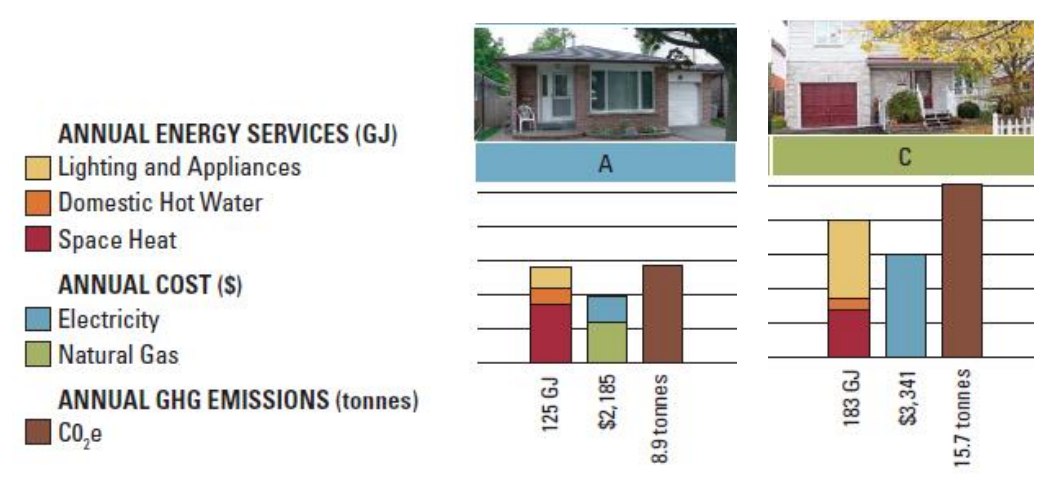

Figure 3: 1970s Single Family Detached Houses in Clarington (NRCan-CanmetENERGY, 2009)

\subsection{High Performance Buildings; Energy-Saving Retrofit Technologies to Reduce Energy Demand}

Retrofitting the existing building to achieve high performance is more complex than the design of new building. According to Bassett, E., \& Shandas, V. (2010), deep retrofit must consider the 
integrated system consisting of smart new materials for envelope, better sensors for control, and more efficient HVAC system. All these systems have to be integrated and operated dynamically responding to exterior condition, occupant's needs, and their behaviour.

High performance buildings have low annual energy demand and heating and cooling energy consumption. This annual energy demand can be measured by $\mathrm{kWh} / \mathrm{m}^{2}$ and may vary according to size and types of houses. Many American cities are implementing energy efficiency action strategies for existing buildings to reduce 30\% energy use in the community level residential sector (Bassett, E., \& Shandas, V., 2010). According to Foley (2012), the energy efficiency could increase by $50 \%$ by retrofitting the building. Blaszak \& Richman (2013) adopted the same target for the annual energy consumption of $100 \mathrm{kWh} / \mathrm{m}^{2}$ for heating and cooling load which is a $50 \%$ reduction of Toronto's average residential house energy consumption- 204 $\mathrm{kWh} / \mathrm{m}^{2}$ provided by EcoENERGY database (Natural Recourse of Canada, Ottawa). Jermyn (2014) targeted $75 \mathrm{kWh} / \mathrm{m}^{2}$ energy intensity of annual heating and cooling load for Century and War time archetype houses. As a continuation of Jermyn's (2014) thesis project, this research paper followed the same target of $75 \mathrm{kWh} / \mathrm{m}^{2}$ for annual heating cooling consumption.

Passive house standard refers to high performance standard for buildings constructed in Germany in 1996. According to this standard the maximum heating and cooling energy consumption should be $15 \mathrm{kWh} /\left(\mathrm{m}^{2} \mathrm{yr}\right)$ of heated living space and the maximum air change rate should be $0.6 \mathrm{ACH}$ at $50 \mathrm{~Pa}$ (Passive House Institute, 2013a). It was found that it is more difficult to feasibly achieve passive house standard in older buildings with reasonable effort. (Passive House Institute, 2012). The use of passive house technology in existing building components does lead to considerable improvement with respect to thermal comfort, structural protection, cost-effectiveness, and energy requirements (Passivhaus, 2011). From this point of view, in Germany, Passive House Institute created the EnerPHit standard for renovation and retrofit houses to achieve high performance standard with lower energy demand. According to 
EnerPHit standard, the maximum heating cooling energy consumption should be $25 \mathrm{kWh} /$ (m2yr) of heated living space, and the maximum air change rate should be $1 \mathrm{ACH}$ at $50 \mathrm{~Pa}$ (Passive House Institute, 2012). This standard provides an ambitious target for retrofitting houses.

In this research, the annual heating cooling target is determined at $75 \mathrm{kWh} / \mathrm{m}^{2}$ for $1970 \mathrm{~s}$ OBC houses. High performance building envelope and HVAC retrofit adapted from OBC 2012, Mucciarone (2011) \& Straube (2011) at three levels to verify the energy reduction. Mucciarone (2011) established sustainable retrofitting for residential house considering thermal performance, moisture performance, constructability, and overall environmental impact. The author suggested different levels of brick and wood frame wall retrofitting and assemble techniques for sustainable renovation. John Straube (2011) offered high level of thermal insulation or high $\mathrm{R}$ enclosures for new and existing building retrofits for energy reduction in all climate zones. The high resistance building envelope assemblies for wood frame structure developed by Straube (2011) is adapted for the highest level retrofitting option in current research to verify the lowest energy reduction possibility.

\subsection{Moisture Stability}

According to Smulski (1999), moisture durability becomes one of the major concerns when the home is more insulated and airtight. In old houses, the permeable building envelope removes moisture by natural infiltration and exfiltration and decreases the moisture accumulation and deterioration of the envelope (Smulski, 1999). Lstiburek (2002) mentioned about moisture balance, moisture storage capacity, and drying time by which the moisture deterioration can be determined in building. The building envelope should be designed in that way to be durable in terms of overcoming moisture issues. Johansson, Ekstrand-Tobin, Svensson, and Bok (2012) mentioned wood building materials are the most at risk of mold growth. The wood structured 
building should be given more concerns regarding mould issues. According to Allinson and Hall (2010) and Johansson et al. (2012) when the relative humidity of wall surface is more than $80 \%$ there is an increase possibility of mould growth. Hukka and Viitanen (1999) also mentioned the same rate of $\mathrm{RH}$ level and stated at $75 \% \mathrm{RH}$ level no mould growth occurs. The hygrothermal analysis of building envelope can help to verify the possibility of moisture damage and deterioration within envelope. 1970s OBC archetype houses are wood structure, so it is important to select the retrofitting assembles of envelope system which consists maximum $\mathrm{RH}$ level of $80 \%$ to confirm its moisture durability.

In this research, the building envelope retrofit levels for1970s OBC houses followed the same as retrofit level for war time wood structured houses developed by Jermyn (2014) as this is a continuation of his research paper. Mucciarone (2011) developed the specific wall assembly of wood structured houses which characterizes a large portion of the Toronto building stock was followed by Jermyn (2014) for war time wood structured houses wall assembly. In this research paper the same assembly has been adopted for 1970s OBC wood structured houses except $R$ value of insulation. Jermyn (2014) considered hygrothermal analysis for 3 levels of retrofit for wall, roof, foundation wall, and slab assemblies for Wartime houses. By hygrothermal analysis, the numbers of condensation and decay hours were compared for the baseline and retrofitted assemblies and verified the moisture permanence (Jermyn, 2014). WUFI Pro 5.2 software was utilized for hygrothermal analysis and the $\mathrm{RH}$ level of all materials was set to $80 \%$ to confirm moisture durability. As hygrothermal analysis for retrofitted envelope was already verified by Jermyn, 2014, it can be stated that all retrofitted stages are durable in terms of moisture resistance.

\subsection{Energy Modeling for High Performance Retrofit}

Rysanek and Choudhary (2013) recommended energy modelling for energy analysis and informed that energy modelling is the benchmark by which the researcher can investigate 
retrofit strategies for the house. Blaszak \& Richman (2013) used Hot2000 software to investigate the energy consumption of various archetypes houses in Toronto. Zirnhelt (2013) \& Jermyn D. (2014) in their research paper used EnergyPlus software for energy model development, analysis and calibration process. In the current research project, the 1970s OBC house energy investigation involved EnergyPlus software and compared the result with Blaszak \& Richman (2013) Hot2000 result to adopt a comparative validation. EnergyPlus software is capable of highly comprehensive and accurate modelling, and has gone extensive testing and validation (Crawley 2004, Henninger \& Witte 2013).

Jermyn (2014) in his research paper followed Dembo (2011)'s retrofit strategy that utilized a Brute Force Sequential Search (BFSS) method to select potential upgrades to new residential buildings. In this process, a number of retrofit options selected and applied individually in the base case and the appropriate upgrade was determined based on lowest life cycle cost. This method limits the total combined upgrades of the house by adopting selected economical solution. Also this method considers the relationship between upgrades in the house. After choosing the first upgrade, the subsequent upgrades are assessed considering their relationship to the first one. This method does not rely on designer's expertise to select the appropriate upgrades of the house.

In the current research project, Jermyn (2014) methodology of deep retrofitting has been adopted to determine the high performance retrofit for 1970s OBC houses. Brute Force Sequential Search (BFSS) method has been followed to select the appropriate retrofit option. The cost benefits of different retrofit selections have been adapted to verify the feasibility. The main focus will be given in selecting the appropriate retrofit option which should be economically worthy and help to save energy to achieve target energy consumption. 


\section{Methodology}

\section{PHASE 1: IDENTIFICATION OF NEIGHBOURHOOD AND DATA COLLECTION}

Neighbourhood mapping and selection based on:

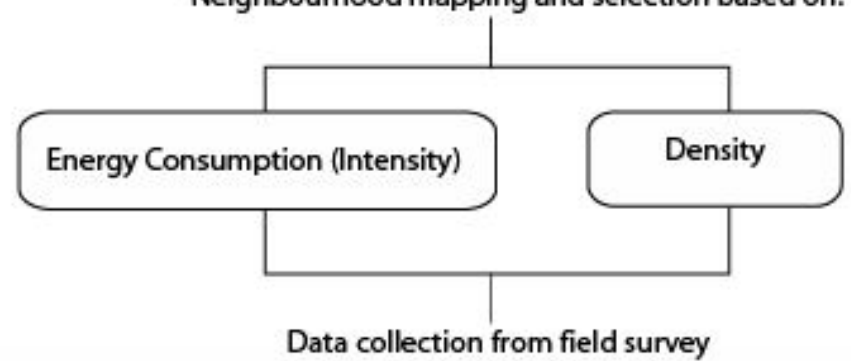

PHASE 2: ENERGYMODELING \& BASE CASE PREPERATION

Identification of Parameters of 70s OBC Houses from:

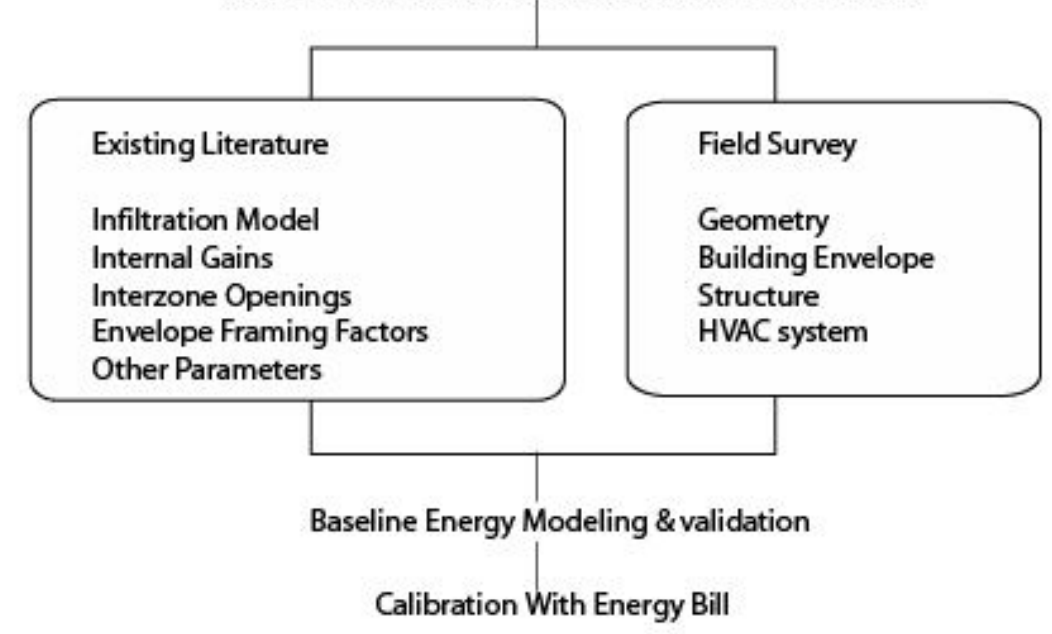

PHASE 3: RETOFIT OPPORTUNITIES FOR TARGETED PERFORMANCE

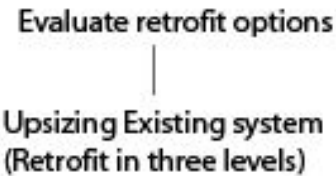

\section{VERIFICATION OF RETROFITS AND RECOMMENDATIONS}

Verify results and feasibility

Recommendations

Figure 4: Sequential Method of Research 
As illustrated in figure 4, the investigation of 1970s OBC single detached and semi-detached houses and examination of their retrofit opportunities is divided into three sequential phases:

Phase1: The first phase performed an in depth GIS (geographical information system) analysis to identify suitable neighbourhoods and single detached and semi-detached houses that will help to create a baseline model of this archetype for further energy analysis. A comprehensive field survey is conducted to collect required data as parameters for energy modeling.

Phase 2: After collecting data from field survey and literature, a base case has been prepared for further analysis through energy modeling. The base line energy model has been validated through calibration to confirm the accuracy of the model.

Phase 3: The last phase involves evaluation of high performance envelope and HVAC system

to achieve target requirements of $75 \mathrm{kWh} / \mathrm{m}^{2}$ for heating and cooling load. Logical upsizing of existing system to minimize retrofit cost and achieve targeted energy performance.

The final step of the research reviews and analyses the results to underline key issues that need to be considered for retrofitting 1970s OBC single detached and semi-detached houses and provides a series of recommendations for potential retrofitting opportunities.

\section{Phase 1- Selection of Neighbourhoods:}

The main purpose of this selection process is to identify appropriate neighbourhoods which significantly represent 1970 s OBC archetype houses, and have high energy consumption rates. The research considers housing type, geographic area, intensity of energy consumption, and density of housing types for the neighbourhood selection process. Selection of housing type is limited to single detached and semi-detached houses. Row housing and multiunit residential houses have been excluded from the selection process. The geographic area is limited within the border of Old Toronto area with an intention to keep in line with similar study area of existing 
literature on other archetypes, particularly Century and War-Time houses. The City of Toronto neighbourhood profile data (2014) and Statistics Canada census data (2006) are utilized to complete the selection process. A total of 43 neighbourhoods of Old Toronto have been considered to investigate 1970s OBC single detached and semi-detached houses.

The neighbourhood selection follows a process of sequential approach to identify single detached and semi-detached houses that represent higher consumption rate of these archetypes. The neighbourhood selection has been performed with following considerations:

1. In the first approach, this research identified neighbourhoods with overall higher intensity of energy consumption and tried to compare it with their density of 1970 s OBC single detached and semi-detached houses. The first step identifies that most of the high intensity energy consumption comes from the neighbourhoods where the density of houses are insignificant. Due to this limitation and lack of survey participation from these areas, a second approach has been adapted.

2. In the second approach, neighbourhoods have been selected based on higher density of 1970s OBC houses. Then they are prioritized based on their intensity of energy consumption. The final selection of neighbourhoods is done based on the assumption that this group of houses have significant contribution in overall energy consumption, and they are more available for survey participation because of their higher density.

To calculate the number of houses and energy intensity of 1970s OBC single detached and semi-detached houses, Jermyn (2014)'s research method is adapted. To identify the density, "Social Profile \#3-Neighbourhoods Families \& Dwellings" 2006 data was utilized. From the social profiles - 'Private Dwellings by Structure Type' are collected to find out the proportion of each type of building in the neighbourhood including single-detached and semi-detached houses (Jermyn D., 2014). The "Buildings by Period of Construction" data is utilized to 
determine the proportion of each archetype houses defined by Blaszak and Richman (2013) and it was assumed that the percentage of buildings built in each construction period represented the percentage of single and semi-detached homes built in the same period (Jermyn D.,2014). The categories of 1970s houses are similar to Statistics Canada's "Buildings by Period of Construction" which is 1970s OBC, 1971-1980. Appendix A presents the summary of 43 neighbourhood's density for 1970s OBC archetype houses collected from the census data 2006.

To estimate the energy intensity of detached houses for 43 neighbourhoods of Old Toronto the equation from Jermyn's (2014) research has been adapted to measure overall neighbourhood energy intensities (appendix A). The combination of higher energy intensity and density of 1970s OBC houses have been initially considered to select the neighbourhoods. However, finally north, east \& west peripheral areas of Old Toronto have been focused to select neighbourhood and archetype house survey because of higher density and availability of participants in those areas.

\subsection{GIS Mapping for 1970s OBC Archetype House \& Neighbourhood Selection}

All maps in neighbourhood selection section are produced by GIS (geographic information system) software to visualize the data collected from the City of Toronto 2006 neighbourhood profile statistics. The neighbourhood map is collected from Ryerson Geo-Data and Map Library as GIS shape file. The density and energy intensity data of 1970 s OBC detached and semidetached houses are imported to GIS software to overlay on the neighbourhood map for analyzing their locations to help the neighbourhood selection process.

Figure 5 and 6 shows comparison of density between all single detached houses and 1970s OBC houses within urban old Toronto's 43 neighbourhoods. The numbers of single detached and semi-detached houses are collected from Statistics Canada census data, which is provided 
in Appendix A. After investigating the neighbourhood profile data it is found that not all high density neighbourhoods consist of large quantity of 1970s OBC archetype houses. Selected neighbourhoods are observed to identify how many 1970s houses exist and contribute in overall energy consumption of those areas. It is found that the central and south of Toronto has low number of single detached and semi-detached houses. It is also found that there are few number of this archetype houses (Figure 5 and 6) exist in central and southern Toronto but the peripheral neighbourhoods have higher density of 1970s houses.

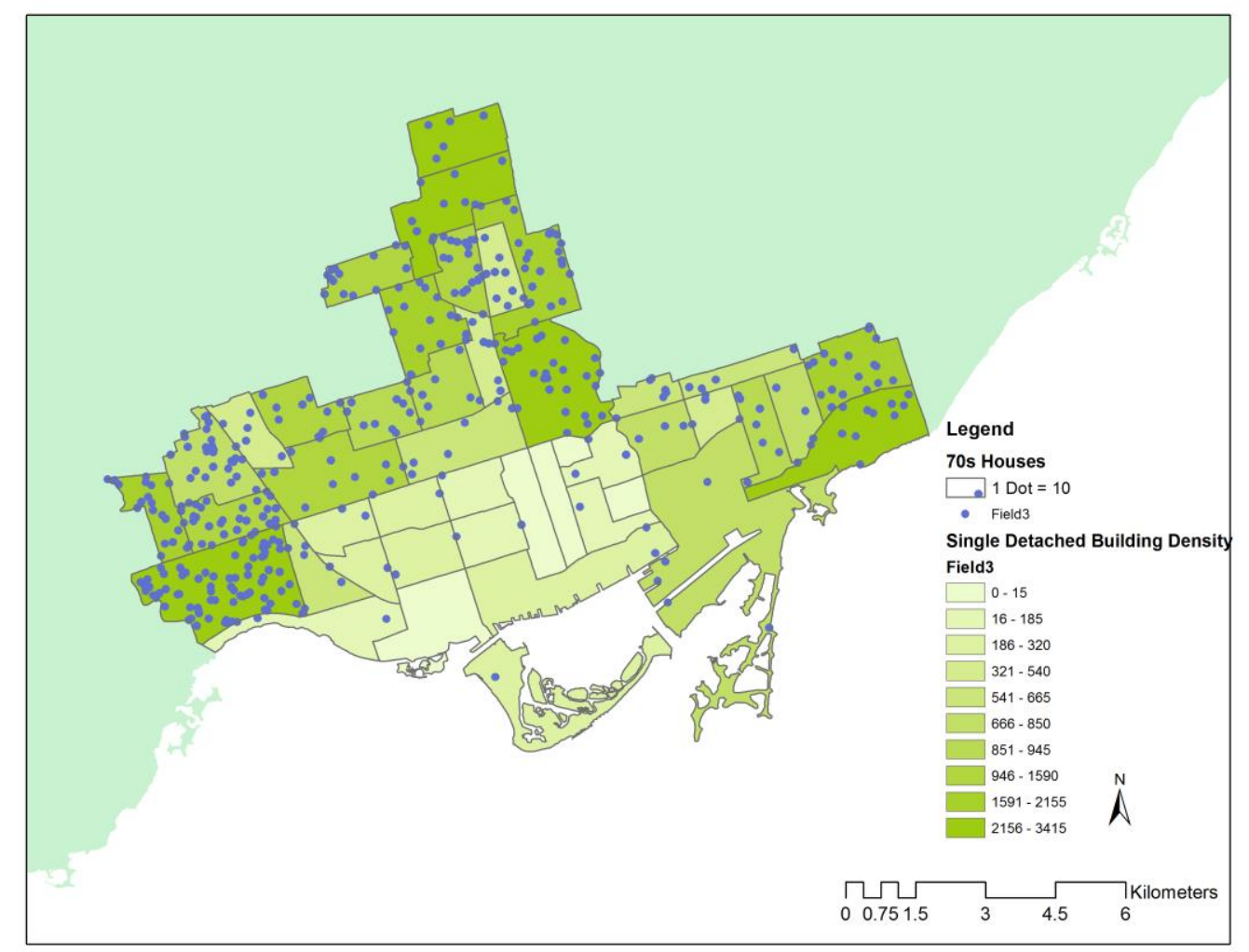

Figure 5: Density of All single-Detached Houses in Comparison with the Number of 1970s Single Detached Houses 


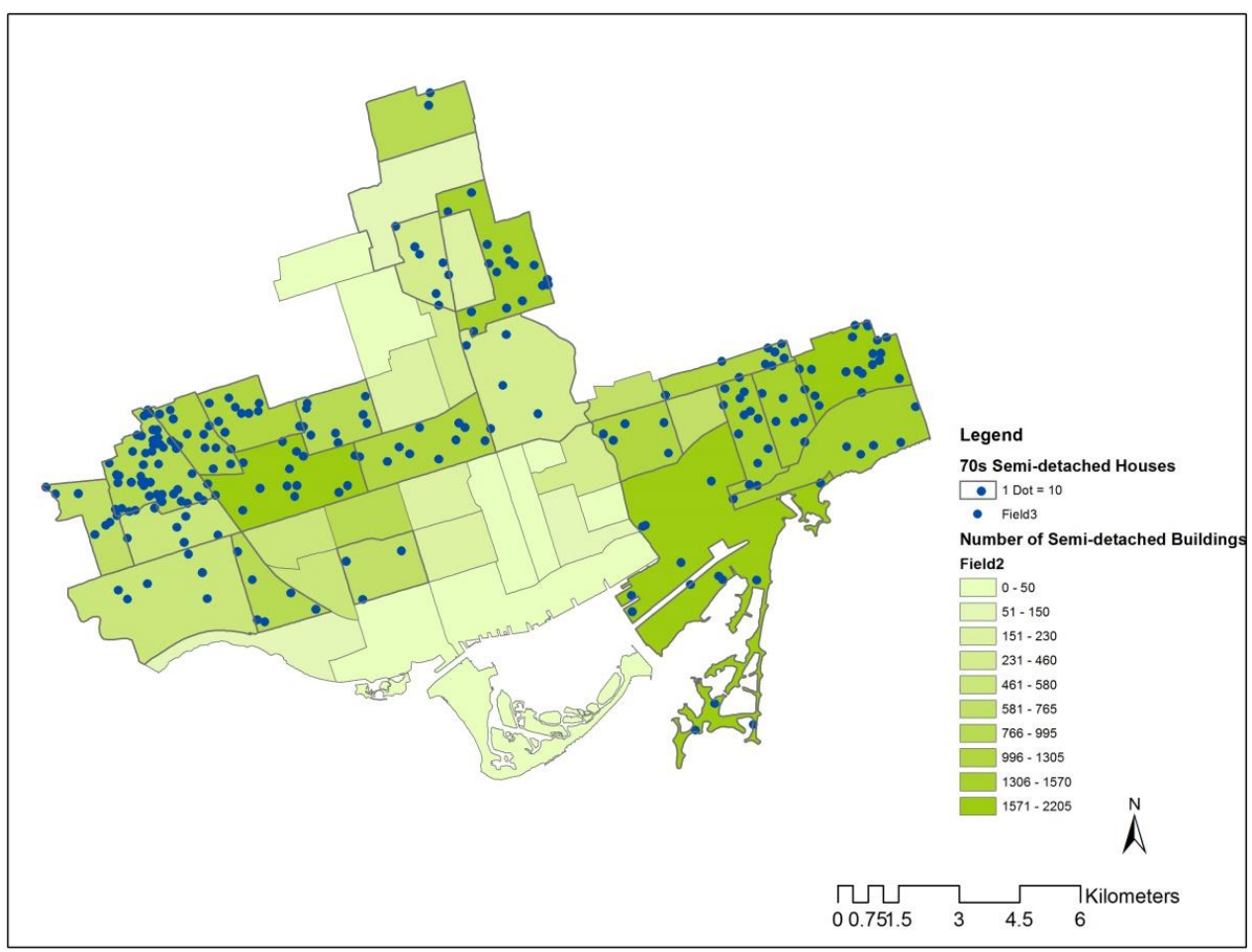

Figure 6: Density of all Semi-Detached Houses in Comparison with the Number of 1970s SemiDetached Houses

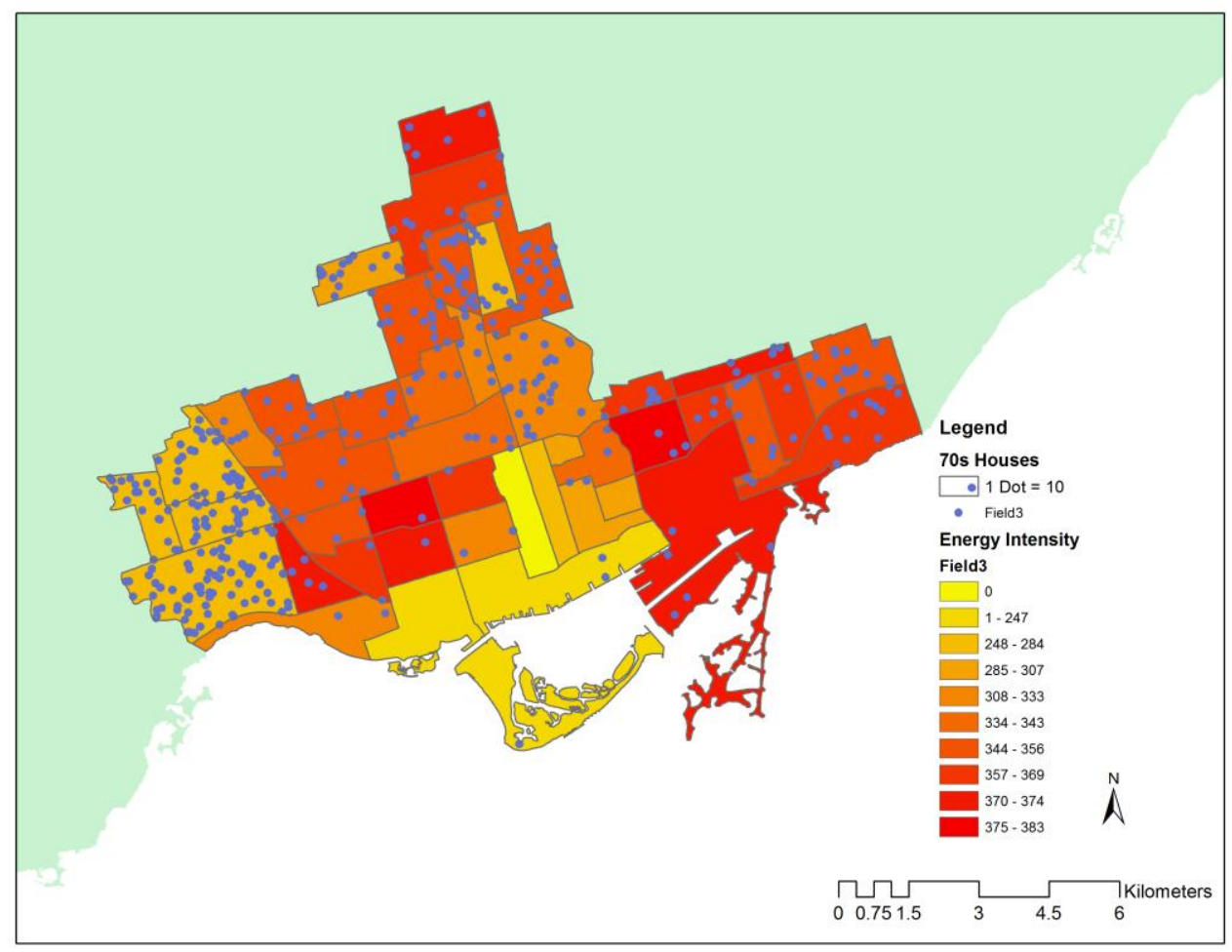

Figure 7: Density of 1970s Semi-Detached Houses in Comparison with the Energy Intensity 
In the first contemplation, the energy intensity based on neighbourhoods is overlaid with the number of 1970s houses of the correspondent neighbourhoods. A GIS mapping analysis reveals (Figure 7) that most of the higher intensity neighbourhoods (Rosedale-Moore Park, Mount Pleasant East \& Yonge-Eglinton) have lower density of 1970s houses. The initial physical survey of these neighbourhoods also indicates that many of these houses have already been renovated. These observations put forward two facts:

- Due to lesser density, 1970 s houses in higher intensity (energy) neighbourhoods have less contribution in overall energy consumption

- Because of higher rate of renovation among these houses in these neighbourhoods; it is more likely that these houses will not provide desirable result in preparing baseline condition.

From the first mapping analysis, it is apparent that neighbourhoods with higher intensity energy consumption do not necessarily represent 1970s OBC houses with higher energy consumption. Availability of participant housed owners is also an important factor in choosing neighbourhoods. These limitations led the selection process to a second approach.

In the second approach, neighbourhoods with higher density of 1970 s houses have been identified and analysed with their correspondent energy intensity. By investigating the density of this archetype and neighbourhood energy intensity, it is found that the neighbourhoods at west and north (High Park-Swansea, High Park North, Junction Area and Forest Hill North) of Toronto have higher number of 1970 s houses but the energy intensity is moderately low. One of the reasons is considerably low presence of Century and War Time houses in these areas. However, these neighbourhoods still has value to consider for detail survey because of the following reasons: 
- From the Literature review it is apparent that energy consumption rates of War Time and 1970s OBC house are not drastically different. Hence it is worth considering neighbourhood of high density 1970s OBC houses for a comprehensive survey to produce a baseline condition.

- Based on preliminary investigation, it is found that the residents of the high density 1970s OBC house neighbourhood are more available for survey participation.

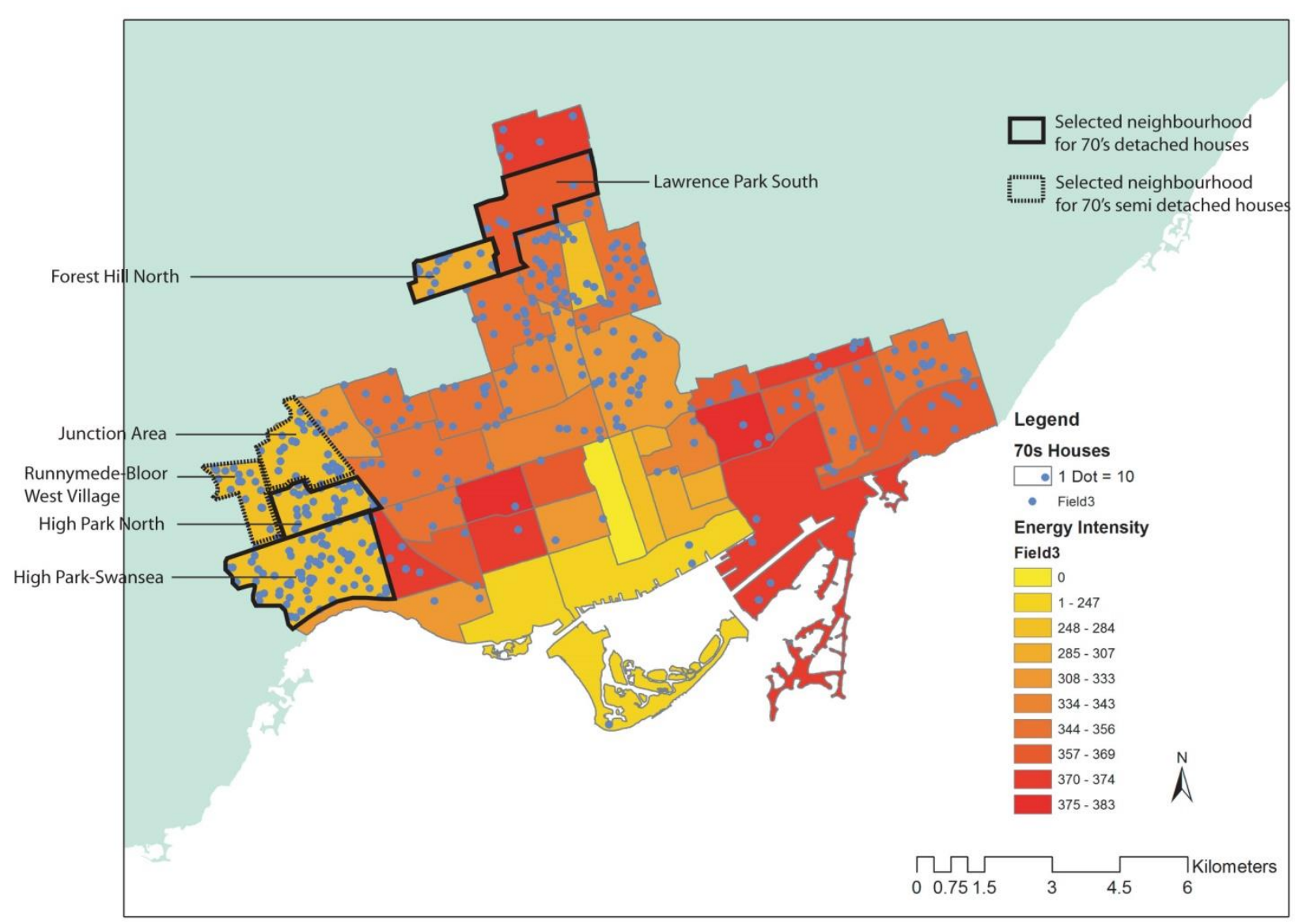

Figure 8: Map Showing Selected Neighbourhoods for Field Survey

It is found that the combination of high density and high energy intensity neighbourhood, 1970s OBC archetypes has moderate energy consumption (260-365 kWh/ $\left.\mathrm{m}^{2}\right)$. However, production of baseline model of these archetypes will provide valuable information of what extent energy 
retrofitting would be viable to increase their energy efficiency. Table $3 \& 4$ illustrates selected neighbourhoods' density and energy intensity.

Table 3: Selected Neighbourhoods for Single Detached Houses Survey \& Energy Intensity Profile

\begin{tabular}{|l|l|l|l|l|}
\hline & Neighbourhood & $\begin{array}{l}\text { Number of } \\
\text { Single Detached } \\
\text { Houses }\end{array}$ & $\begin{array}{l}\text { Number of } \\
\text { 1970s OBC } \\
\text { Archetype } \\
\text { Houses }\end{array}$ & $\begin{array}{l}\text { Energy } \\
\text { intensity }\end{array}$ \\
\hline & WEST & & & \\
\hline 87 & High Park-Swansea & 2620 & 745 & 260 \\
\hline 88 & High Park North & 1375 & 301 & 268 \\
\hline & NORTH & & & \\
\hline 102 & Forest Hill North & 1450 & 139 & 298 \\
\hline 103 & $\begin{array}{l}\text { Lawrence Park } \\
\text { South }\end{array}$ & 3415 & 77 & 365 \\
\hline
\end{tabular}

Table 4: Selected Neighbourhoods for Semi-Detached Houses Survey \& Energy Intensity Profile

\begin{tabular}{|l|l|l|l|}
\hline & Neighbourhood & $\begin{array}{l}\text { Number of Semi } \\
\text { Detached Houses }\end{array}$ & $\begin{array}{l}\text { Number of 1970s } \\
\text { OBC Archetype } \\
\text { Semi Detached } \\
\text { Houses }\end{array}$ \\
\hline 89 & $\begin{array}{l}\text { Runnymede-Bloor West } \\
\text { Village }\end{array}$ & 765 & 60 \\
\hline 90 & Junction Area & 965 & 488 \\
\hline
\end{tabular}

\subsection{Field Survey of 1970s OBC Archetype Houses}

After neighbourhood selection through a GIS mapping analysis, the main challenge was to identify individual units that represent 1970s OBC archetype. Direct field investigation to identify the age of building was a challenge due to time limitation and lack of responses from the house owners. To identify this archetype houses, City of Toronto's archive map of individual units selected by construction period is utilized. Figure 9 illustrates Toronto's individual buildings/lots by construction of periods produced by City of Toronto survey \& mapping services (2006). A detail exploration of 1970s OBC archetypes (light green color lots in figure 9) and further investigation through Google map and field visit helped to identify single detached and semi- 
detached residential houses. A request for field survey and data collection was sent to selected house owners for the purpose of energy modeling and base model creation of single and semidetached houses.

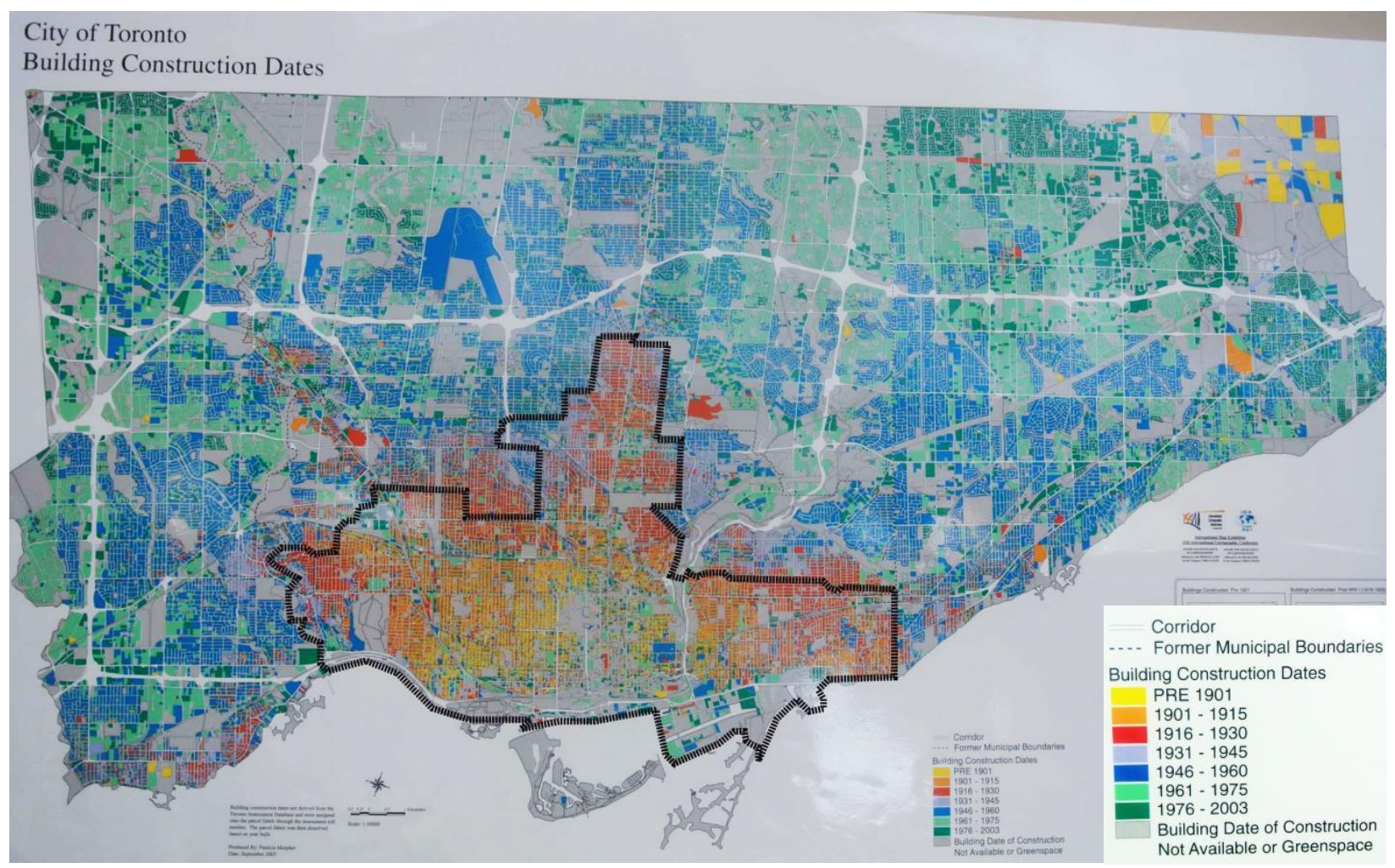

Figure 9: City of Toronto Map of Individual Units/Lots by Construction Periods (Source: Toronto Achieves)

The research primarily focused on neighbourhoods of high density 1970 s OBC houses which include both single and semi-detached houses. This allows illustrating a set of architectural and structural characteristics that can be established as most common features of 1970 s houses. After a thorough investigation, it is apparent that this archetype consists of some repetitive and common features among selected neighbourhoods which are not all similar to the features mentioned by Blaszak and Richman (2013). The major difference found from Balszak's 1970s OBC archetype is an addition of attached garage leading by a driveway. The features found in 
the field survey are identical for both single detached and semi-detached residential houses. The major features for 1970s OBC houses within old Toronto are-
1) Shallow hip roof
2) Partially raised \& recessed entry
3) Semi basement garage \& driveway on one side of lot
4) Extended veranda on garage (not in all houses)
5) Large proportion of front window (flat windows)

1970s Archetype Characterized by Blaszak (2010)

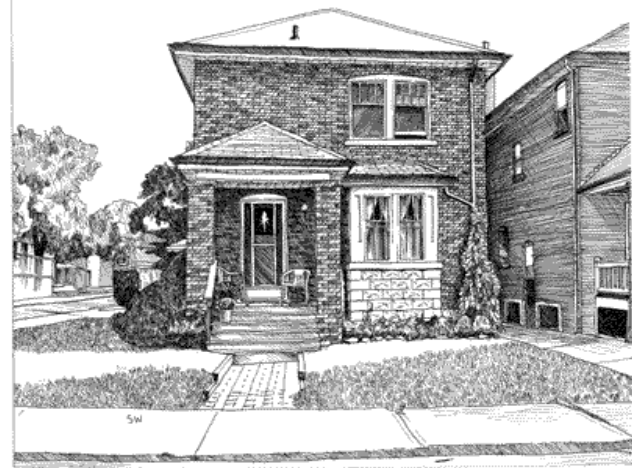

1970s Archetype Characterized from Field Survey (Photograph by Sharmeen Niger, 2015)

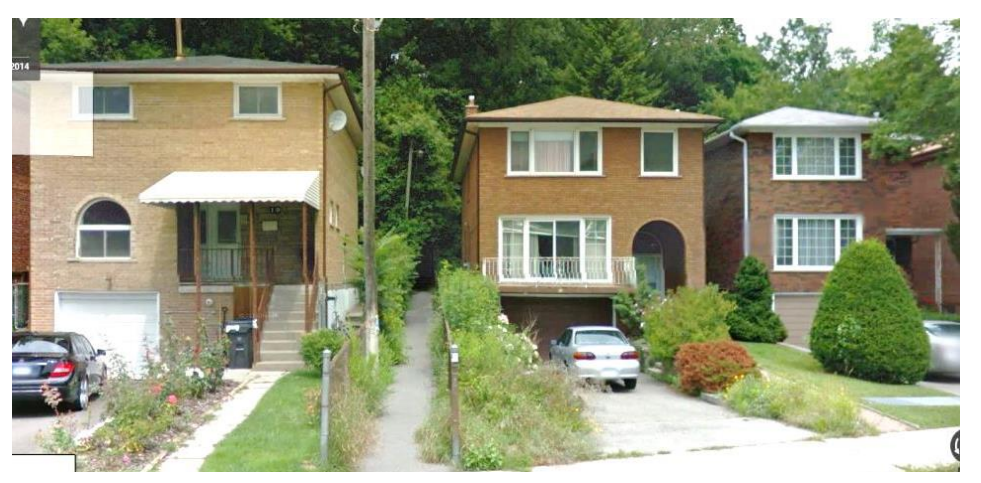

Figure 10: 1970s Archetype Characteristic Compared Between Blaszak (2010) and this Research Survey.

Three major archetype categories are found from 1971 to1980 time period houses. Which are-

1) 1970s OBC Single Detached House (garage incorporated in the lower level in most cases)

2) 1970s OBC Bungalow House (garage incorporated in the lower level in some cases)

3) 1970s OBC Semi-detached House (garage incorporated in the lower level in most cases)

There are few other archetypes also evident in this timeframe (1971-1980) which includes single detached houses without garage which are mostly located within the downtown area. It is clear that due to smaller lot area and topographical reasons these houses do not have garage 
attached. Due to smaller number of samples, this research did not consider this archetype for data collection. Some of the semi-detached houses are also found without garage which is not considered for the same reason.

Type 1: 1970s OBC Single Detached

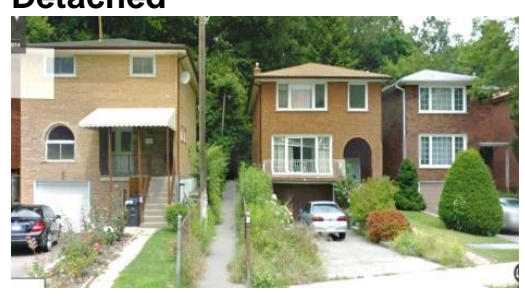

Type 2: 1970s OBC Bungalow

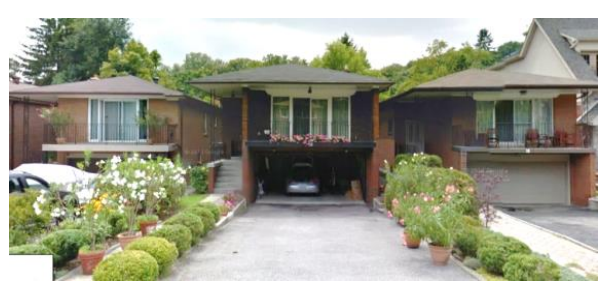

Type 3: 1970s OBC SemiDetached

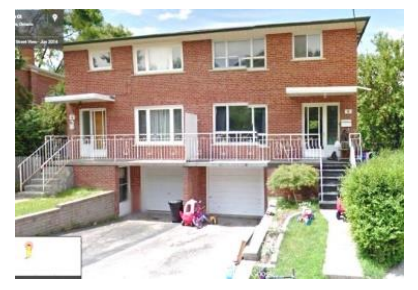

Figure 11: 1970s Archetype Categories Identified in the Field Survey

Table 5: The Most Common Features of Detached and Semi-Detached 1970s OBC Houses

\begin{tabular}{|l|l|l|l|}
\hline Archetype & \multicolumn{3}{|c|}{ 1970s OBC } \\
\hline Features & Type 1 & Type 2 & Semi Detached \\
\hline & & Bungalow House & \\
\hline No of Storeys & 2.5 & 2 & 2.5 \\
\hline Plan Shape & Rectangle & Rectangle & Rectangle \\
\hline Parking & Basement parking & Basement parking & Basement parking \\
\hline Vintage & $1971-1980$ & $1971-1980$ & $1971-1980$ \\
\hline Lot Placement & Driveway on one side & Driveway on one side & Driveway on one side \\
\hline & Partially raised basement, & Ground floor parking, & Partially raised \\
Features & Narrow awning & Narrow awning & basement, Narrow porch \\
\hline Roof & Low height hip roof & Low height hip roof & Low height hip roof \\
\hline Structure & Light-wood Frame & Light-wood Frame & Light-wood Frame \\
\hline Cladding & Brick & Brick & Brick \\
\hline
\end{tabular}

Although Bungalow houses have unique character, this archetype was also excluded from this research for further investigation because this archetype is also very few in number and only concentrated in few locations. Single detached and semi-detached houses with garage are two most common archetypes found in most locations among the selected neighbourhoods which have identical characteristics (table 5) and selected for the production of baseline model for 
further energy analysis. Table 6 illustrates number of single detached and semi-detached houses selected for data collection from different neighbourhoods.

Table 6: Number of Houses Surveyed in Selected Neighbourhoods

\begin{tabular}{|l|l|l|l|l|l|}
\hline Hood\# & Neighbourhood & $\begin{array}{l}\text { Number of } \\
\text { detached food\# } \\
\text { houses for } \\
\text { survey }\end{array}$ & Neighbourhood & $\begin{array}{l}\text { Number of } \\
\text { semi- } \\
\text { detached } \\
\text { houses for } \\
\text { survey }\end{array}$ \\
\hline & WEST & & & & \\
\hline 87 & High Park-Swansea & 1 & 89 & $\begin{array}{l}\text { Runnymede-Bloor West } \\
\text { Village }\end{array}$ & 1 \\
\hline 88 & High Park North & 1 & 90 & Junction Area & 2 \\
\hline \multicolumn{7}{|l}{} & \multicolumn{3}{|l}{} \\
\hline 102 & NORTH & Forest Hill North & 1 & & \\
\hline 103 & Lawrence Park South & 1 &
\end{tabular}

\section{Phase 2- Data collection for Baseline Energy Modelling:}

In second phase of the research, selected detached and semi-detached houses are surveyed to prepare the baseline energy model by which the energy consumption of 1970s OBC house can be accessed and verified with literature and energy bills. Formal survey material has been prepared through the process of Ryerson Ethics Board (REB) Approval (appendix B) and a structured questionnaire (appendix $\mathrm{C}$ ) has been provided to the interested participants. The survey also includes site visit and interview with interested participants. Four detached and three semi-detached houses are surveyed to collect data for the baseline model. EnergyPlus software is used to prepare the baseline energy model. As a continuation of Jermyn (2014)'s research project, the same methodology has been adopted for data collection, energy modelling, parameters input and calibration to prepare and validate the base model. Jermyn (2014) in his research project focused on energy consumption of War Time and Century single and semi-detached houses in Toronto, whereas this research paper focuses on 1970s OBC archetypes within the boundary of old Toronto. The data required to prepare the model are the followings: 
Table 7: Parameters Selected for Data Collection and Energy Modeling

\begin{tabular}{|c|c|}
\hline $\begin{array}{ll}\text { - Geometry } \\
\text { - } & \text { Building foot print } \\
\text { - } & \text { Storey height } \\
\text { - } & \text { Dimension } \\
\text { - } & \text { Glazing and doors } \\
\text { - } & \text { Floor plan } \\
\text { - } & \text { Shading device and overhangs }\end{array}$ & $\begin{array}{l}\text { Envelope } \\
\text { - Material and material properties } \\
\text { - Window construction } \\
\text { - Door construction } \\
\text { - } \text { Air tightness }\end{array}$ \\
\hline $\begin{array}{ll}\text { - } & \text { Basement } \\
- & \text { Basement material and material } \\
& \text { properties } \\
- & \text { Below grade wall construction }\end{array}$ & $\begin{array}{ll}- & \text { Internal grain } \\
-\quad & \text { Type of major appliances } \\
-\quad & \text { Occupancy schedule }\end{array}$ \\
\hline $\begin{array}{ll}- & \text { HVAC } \\
- & \text { Type of heating and cooling } \\
- & \text { Location of thermostat } \\
- & \text { Total ventilation flow rate }\end{array}$ & \\
\hline
\end{tabular}

The above mentioned data are collected by a series of site visits, visual observations and questionnaire survey of selected houses. Building features such as height, shading device, window wall ratio, building exterior material are investigated and qualitative data are collected by visual observation. Building footprint data is collected from Greater City of Toronto property CAD map (source Ryerson University Library). In addition to visual observation of houses, floor plans (figure 12) are collected from one of the survey participants' single detached house which helps to create accurate internal zones for baseline model. 


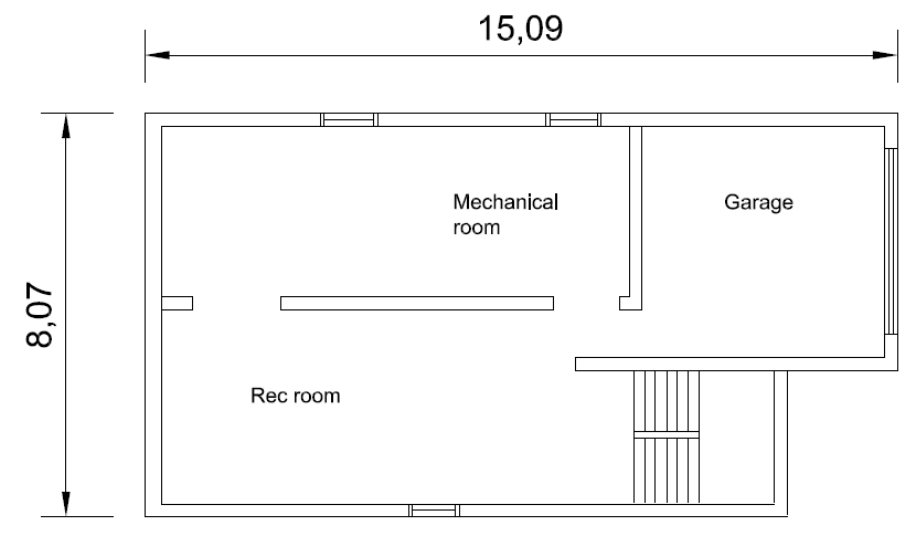

\section{Basement Plan}

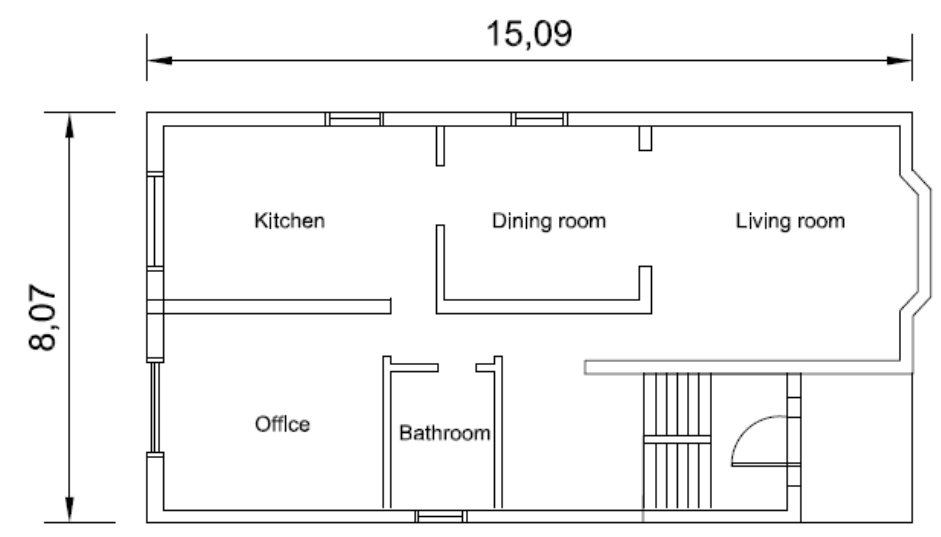

Ground Floor Plan
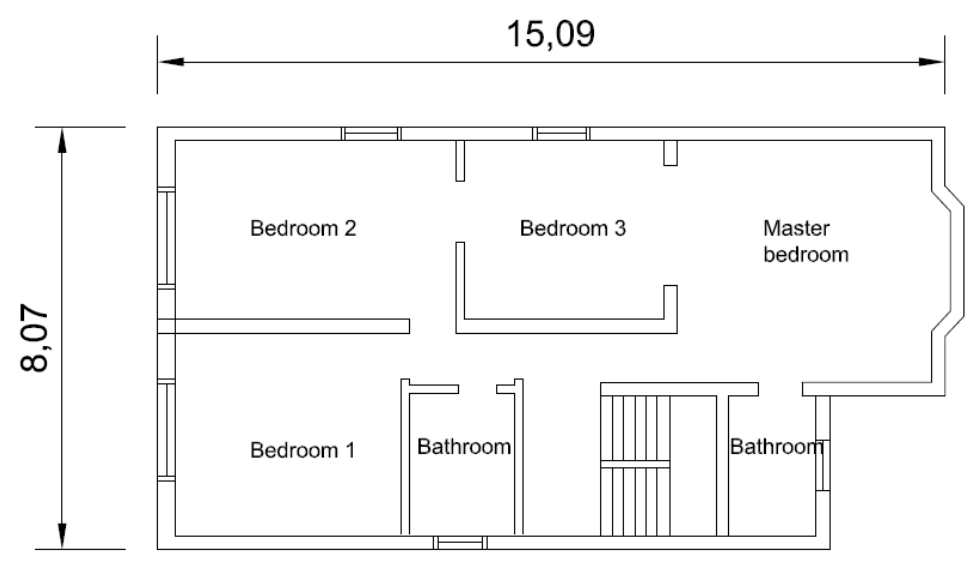

1st Floor Plan

Figure 12: Floor Plans of 1970s OBC Archetype, Source: Collected from Research Participants 
The heated floor area, HVAC system, appliance types and usages, occupancy number etc. are collected from the interview and survey questionnaire (appendix B). Building envelope assembles and airtightness are adopted from Blaszak and Richman (2013) to prepare baseline model of the house. This research collected data from sites and questionnaire survey provided more practical and authentic information to analyse the energy ingestion of existing 1970s houses of urban Old Toronto.

\subsection{Baseline Model Preparation}

\section{0s OBC Single detached House}

Four single detached houses within different neighbourhoods of Old Toronto have been surveyed to collect data to prepare baseline model of 1970 s OBC archetype single detached houses. All the collected data is then complied and averaged to use in EnergyPlus model. The current research is not to model a particular 1970s building moreover focus is given to study several houses and prepare generic data for 1970s OBC archetypes. An average data of the surveyed houses is rational as all of them are identical in size, shape and envelope system. The collected data from field survey for 1970 s OBC single detached house is shown in appendix D. Most of surveyed single detached houses are oriented at north direction. In energy model the front is considered at north orientation. Shallow hip roof found for all houses which modelled in EnergyPlus software. No external shading device was found with windows. The window wall ratio is investigated considering front, rear and two sides of elevations as the actual orientation of all of the surveyed houses are not similar (figure 13). As most of the houses have minimum setback and outdoor exposure from all orientation, it is assumed that all external walls are exposed to sun and $0 \%$ shaded for detached house. 

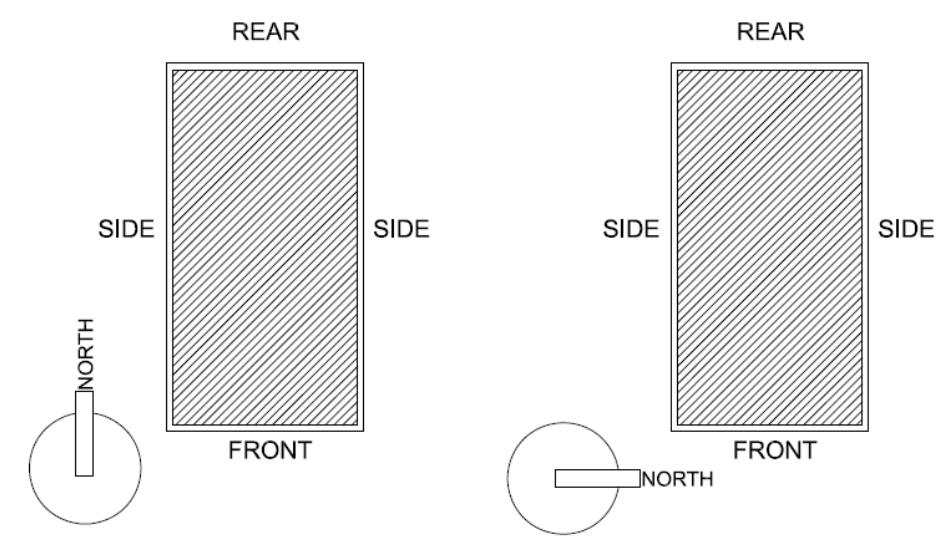

Figure 13: Conceptual Drawings Illustrates that the data are collected based on front, side and rear walls regardless there north orientation

\section{0s OBC Semi- detached House}

In the case of the semi-detached house survey, most semi-detached houses oriented at south. As a result, the baseline model front is considered at south orientation. It is also found that two separate hip roofs are integrated with two units of one semi-detached house. In developing energy model, separate single hip roof with single unit is modeled with EnergyPlus. The shared wall is modelled as exterior wall but considered $100 \%$ shaded as this is a common wall between two units. Building footprint, height, window wall ratio, window framing, door size and number are adopted from average values of 3 surveyed semi-detached houses in different locations (appendix D). The north, south and east faces assumed to be $0 \%$ shaded and west considered as $100 \%$ shaded because of shared wall with adjacent unit.

\subsubsection{Infiltration Model}

To determine infiltration rate for archetype houses Jermyn (2014) utilized EcoENERGY database and air change rate per hour at $50 \mathrm{~Pa}(\mathrm{ACH})$ which is adopted in this research. Zirnhelt (2013) in his research utilized the ASHRAE (2009b) enhanced method for air infiltration input in EnergyPlus and used "Zone Infiltration: Flow Coefficient" object. Zirnhelt (2013) used 
this method as blower test with results available for the houses he modelled. The below equation was used to determine air infiltration by utilizing Design Flow Rate method-

$$
\text { Infiltration }=\left(I_{\text {design }}\right)\left(F_{\text {schedule }}\right)\left[A+B\left|\left(T_{\text {zone }}-T_{\text {odb }}\right)\right|+C(\text { WindSpeed })+D\left(\text { WindSpeed }^{2}\right)\right]
$$

Here A, B, C and D are default coefficients which are generated from EnergyPlus predecessor programs BLAST and DOE-2. Zirnhelt (2013) mentioned that BLAST and DOE-2 coefficient have different impact in simulation result such as BLAST coefficients increases heating energy used by $28 \%$ compared to the DOE-2 coefficients. Gowri et al. (2009) found BLAST coefficients were highly sensitive with temperature and over predict. As a result, Jermyn (2014) utilized DOE-2 coefficient in combination with the $\mathrm{ACH}$ at $50 \mathrm{~Pa}$ values which collected from EcoENERGY database to model the air infiltration for archetype houses. According to $\mathrm{CMCH}$ (2012) the average 6.0 air changes per hour at $50 \mathrm{~Pa}$ was considered for 1970 s two storied houses. The $\mathrm{ACH}$ value collected from Eco ENERGY database was used by Blaszak \& Richman (2013) for 1970s OBC archetype house energy performance investigation. In this research for 1970 s houses, $5.75 \mathrm{ACH}$ at $50 \mathrm{~Pa}$ is adapted from Eco ENERGY database.

\subsubsection{Internal Gains}

Internal heat gain is caused inside the house by the heat releases of occupants, lighting \& appliances. Occupant \& lighting number, types of appliances \& schedule of usages of lighting and appliances significantly impact on internal heat gain of the house. In the field survey of this research the data has been collected for occupancy, lighting and appliances uses. From the survey, it was found that the living and bedrooms are predominantly used and associated with occupants and lighting gains. Basements are not frequently used in whole day and some space used for storage purpose. 
In case of EnergyPlus model Zirnhelt (2013) demonstrated the living and family room as separate zones with same occupancy level but modelled the internal gain separately with different schedule. Several zones were created in Zirnhelt (2013) energy model with different schedules. Jermyn (2014) considered two main categories of spaces - living and sleeping spaces which are associated with occupancy and internal heat gain. The main living and family areas are considered as living space and all bedrooms are as sleeping spaces. Basement was considered as living or storage space according to it intended function.

Jermyn's (2014) energy model zoning methodology is adopted in this research to model 1970s OBC-detached and semi-detached houses. In this research, for 1970s houses, the main level is considered as living space, the bedrooms of upper level are considered as sleeping zone and basement as living zone. Jermyn (2014) modelled the internal gain for the living and family rooms with the same schedule and that was the combination of living and family room schedules modelled by Zirnhelt (2013). In this research the method of Jermyn (2014) is followed to model the internal gain except the semi basement level as there is unused garage space. All zones are prepared according to floor levels and every zone schedule is considered different. At ground level living, dinning and office space is considered as one zone. At the first floor level, all bedrooms considered as other separate zone. At semi-basement level there are two zones; garage space is measured as unheated zone and the recreational areas are considered as living zone.

For both detached and semi-detached houses, five zones mentioned below are created for baseline model:

1) Basement Zone (heated)

2) Garage Zone (Unheated)

3) Living zone (ground floor level) (heated) 
4) Sleeping Zone ( $1^{\text {st }}$ floor level) (heated)

5) Attic Zone (Unheated)

The internal gains from lighting are modelled for living, sleeping and basement zone of 1970s $\mathrm{OBC}$ archetype house. To calculate the internal gain from lighting the energy model utilized watt per zone floor area $\left(\mathrm{W} / \mathrm{m}^{2}\right)$. The living areas were modelled by adapting $1.9 \mathrm{~W} / \mathrm{m}^{2}$ and for the bedroom and office areas is $3.07 \mathrm{~W} / \mathrm{m}^{2}$ by utilizing the schedules of Zirnhelt (2013) which Jermyn (2014) followed. For basement, $1.9 \mathrm{~W} / \mathrm{m}^{2}$ has been assumed as it is considered as living zone. The number of lighting for the houses are collected from survey questionnaire and incorporated in the model.

Internal gain from home appliances is also considered in the archetype model. The types of appliances, power usage, and schedules are based on the calibrated model by Zirnhelt (2013) and Jermyn (2014). This data is also supplemented by the survey data. From survey the types of appliances and schedules of uses are also utilized.

\subsubsection{Interzone Openings \& Envelope Framing Factors}

EnergyPlus does not inherently account for the transfer of energy between thermal zones due to doorways and stairwells (Jermyn D., 2014). According to Zirnhelt (2013), omitting a portion of a wall or floor surface in the building geometry also omits the heat transfer associated with that surface. To resolve this issue doorways and stairwells are modelled as glass surfaces with a high transmittance, high emissivity, high long wave transmittance, and very low thermal resistance as modelled by Zirnhelt (2013) and same methodology was adopted by Jermyn (2014). The methodology of Meldem and Winklemann (1995) was followed to model the heat transfer through the openings by providing different heat transfer coefficient for different opening. For door opening selected coefficient is $11 \mathrm{~W} / \mathrm{m}^{2} \mathrm{k}$ which was provided by Meldem and 
Winklemann (1995) and for stairwell coefficient is $11 \mathrm{~W} / \mathrm{m}^{2} \mathrm{k}$ which was assumed by Zirnhelt (2013). These coefficients are utilized for base model of 1970s OBC archetype house.

\subsubsection{Building Specific Parameters}

The physical features, boundary conditions and HVAC information for the baseline model of 1970s OBC single and semi-detached houses are given below:

\section{Physical features}

- Detached House orientation: North

○ Semi-Detached House orientation: South

- Roof: Hip roof

12 degree (single detached), 8 degree (semi-detached)

$0.91 \mathrm{~m}$ height (single detached), $0.6 \mathrm{~m}$ height (semi-detached)

- $5 \mathrm{~mm}$ Double glazed window with $12 \mathrm{~mm}$ air gap Insulated Door $(0.8 \mathrm{~m} 2 \mathrm{k} / \mathrm{W})$

- $0.46 \mathrm{~m}$ shading as extended roof (no exterior shading device.)

\section{Boundary Conditions}

There are five separate thermal zones consist of the same outside boundary condition which are mentioned below. Toronto weather AMY (Actual Meteorological Year) file is collected from EnergyPlus Weather Data and used in baseline model's weather file option. The boundary condition parameters are:

- Location: Toronto, Canada

- Terrain: City

- Toronto weather 2014

- Simulation control: Weather file run period

○ Run period: 1 year 
$\circ$ Ground Reflection: 0.26

5 zones:

1) Basement Zone (heated)

2) Garage Zone (Unheated)

3) living zone (ground floor level) (heated)

4) Sleeping Zone ( $1^{\text {st }}$ floor level) (heated)

5) Attic Zone (Unheated)

\section{HVAC Model Information}

○ $5.75 \mathrm{ACH} @ 50 \mathrm{~Pa}$ and in normal pressure $0.287 \mathrm{ACH}$

- The heating set point is $20^{\circ} \mathrm{C}$ and cooling set points is $25^{\circ} \mathrm{C}$

- Forced Air System

- $\mathrm{COP}$ is 3

- Gas furnaces efficiency $80 \%$.

- Single speed DX Cooling coil

The other building specific detail parameters for the baseline model of 1970 s OBC single and semi-detached houses are given in table 8 below-

Table 8: Building Specific Parameters for Baseline Model

\begin{tabular}{|c|c|c|c|}
\hline Archetype & 1970s OBC & $\begin{array}{l}\text { 1970s OBC Semi- } \\
\text { Detached }\end{array}$ & Reference \\
\hline Heated Floor Area & $260.7 \mathrm{~m}^{2}$ & $251.5 \mathrm{~m}^{2}$ & Field Study \\
\hline Footprint & $7.5 \mathrm{~m} \times 15.4 \mathrm{~m}$ & $6.1 \mathrm{~m} \times 13.4 \mathrm{~m}$ & Field Study \\
\hline \multicolumn{4}{|l|}{ Building } \\
\hline No of Storeys & 2.5 & 2.5 & Field Study \\
\hline Plan Shape & Rectangle & Rectangle & Field Study \\
\hline Vintage & $1971-1980$ & $1971-1980$ & Blaszak \& Richman (2013) \\
\hline Lot Placement & Adjacent to Neighbours & Adjacent to Neighbours & Field Study \\
\hline Features & $\begin{array}{lr}\text { Partially } & \text { raised } \\
\text { basement, } & \text { Narrow } \\
\text { awning } & \\
\end{array}$ & $\begin{array}{l}\text { Partially raised } \\
\text { basement, Narrow porch }\end{array}$ & Field Study \\
\hline Roof & Hip & Hip & Field Study \\
\hline Structure & Light-wood Frame & Light-wood Frame & Field Study \\
\hline Cladding & Brick & Brick & Field Study \\
\hline Insulation RSI & & & \\
\hline
\end{tabular}




\begin{tabular}{|c|c|c|c|}
\hline Walls & 1.71 & 1.71 & Blaszak \& Richman (2013) \\
\hline Ceiling & 4.18 & 4.18 & Blaszak \& Richman (2013) \\
\hline Foundation & 1.16 & 1.16 & Blaszak \& Richman (2013) \\
\hline \multicolumn{4}{|l|}{ Ceiling Assembly } \\
\hline & Shingle & Shingle & Blaszak \& Richman (2013) \\
\hline & 184mm Fibreglass & $184 \mathrm{~mm}$ Fibreglass & Blaszak \& Richman (2013) \\
\hline & Gypsum & Gypsum & Blaszak \& Richman (2013) \\
\hline \multicolumn{4}{|l|}{ Wall Assembly } \\
\hline & Brick & Brick & Blaszak \& Richman (2013) \\
\hline & 20mm Air Space & 20mm Air Space & Blaszak \& Richman (2013) \\
\hline & OSB & OSB & Blaszak \& Richman (2013) \\
\hline & 64mm Fibreglass & 64mm Fibreglass & Blaszak \& Richman(2013) \\
\hline & Gypsum & Gypsum & Blaszak \& Richman(2013) \\
\hline \multicolumn{4}{|l|}{ Foundation Assembly } \\
\hline & $300 \mathrm{~mm}$ Concrete & $300 \mathrm{~mm}$ Concrete & Mucciarone, A. (2011) \\
\hline & 38mm Fibreglass & $38 \mathrm{~mm}$ Fibreglass & Mucciarone, A. (2011) \\
\hline & Gypsum & Gypsum & Mucciarone, A. (2011) \\
\hline Air Leakage $(\mathrm{ACH} 50 \mathrm{~Pa})$ & 5.75 & 5.75 & EcoEnergy Database \\
\hline \multicolumn{4}{|l|}{ Glazing (\%) } \\
\hline Front & $31 \%$ & $30 \%$ & Field Study \\
\hline Rear & $23 \%$ & $23 \%$ & Field Study \\
\hline Side & $8 \%$ & $11 \%$ & Field Study \\
\hline Side & $3 \%$ & $0 \%$ & Field Study \\
\hline Window Type & Double Glazed Air Filled & Double Glazed Air Filled & Field Study \\
\hline Door Type & Insulated & Insulated & Field Study \\
\hline \multicolumn{4}{|l|}{ HVAC System } \\
\hline Type & Forced Air Gas & Forced Air Gas & Field Study \\
\hline Control Location & Dining Room & Dining Room & Field Study \\
\hline \multicolumn{4}{|l|}{ Internal Gains } \\
\hline Lighting & 1.9 and $3.07 \mathrm{~W} / \mathrm{m}^{2}$ & 1.9 and $3.07 \mathrm{~W} / \mathrm{m}^{2}$ & Zirnhelt (2013) \\
\hline Appliances & Kitchen/Hot Water & Kitchen/Hot Water & Field Study \\
\hline Occupancy & 4 people & 3 people & Field Study \\
\hline \multicolumn{4}{|l|}{ Framing Factor } \\
\hline Exterior Wall & $31.40 \%$ & $31.40 \%$ & Qasass et al. (2014) \\
\hline Interior Wall & $15.00 \%$ & $15.00 \%$ & Zirnhelt (2013) \\
\hline Floor & $11.70 \%$ & $11.70 \%$ & Qasass et al. (2014) \\
\hline Roof & $8.60 \%$ & $8.60 \%$ & Qasass et al. (2014) \\
\hline
\end{tabular}

The different features of the building and data are collected from field study and updated with the original data of Blaszak (2010). Building envelope insulation levels are adapted from Blaszak \& Richman (2013) and assemblies are developed according to Mucciarone's (2011) wood frame construction assemble which applied for most of Toronto's wood frame structure houses. Airtightness data is collected from EcoENERGY database for the archetype. All the collected data are applied to base case energy model. 


\subsubsection{0s OBC Single Detached House Baseline Model and Validation}

Utilizing field survey data, figure 14 shows the geometry of 1970 s OBC single detached house developed by Legacy Open Studio - a SketchUp Plugin. The energy simulation is accomplished by EnergyPlus simulation software. The baseline input details are shown in table 8 . In this research for 1970s OBC detached house, it is found that total energy use is $50,277 \mathrm{kWh}$ over one year simulation period and energy intensity is $193 \mathrm{kWh} / \mathrm{m}^{2}$ which is comparatively very low than other archetype's energy usage (Century House- $236 \mathrm{kWh} / \mathrm{m}^{2} \&$ War-Time Home- 255 $\mathrm{kWh} / \mathrm{m}^{2}$ ) investigated by Jermyn (2014) with EnergyPlus software. The reason can be 1970 s houses are relatively more airtight and consists higher insulation (1970s OBC code) than older houses. Additionally, considering the heating-cooling load, the energy use for baseline model is found $41,944 \mathrm{kWh} /$ year and energy intensity $161 \mathrm{kWh} / \mathrm{m} 2$. To perform a comparative analysis and to ensure the appropriateness of this result, the baseline result is compared with:

1) Blaszak \& Richman (2013) and

2) Natural Resource Canada -CanmetENERGY, (2009) 1970s archetype projects.
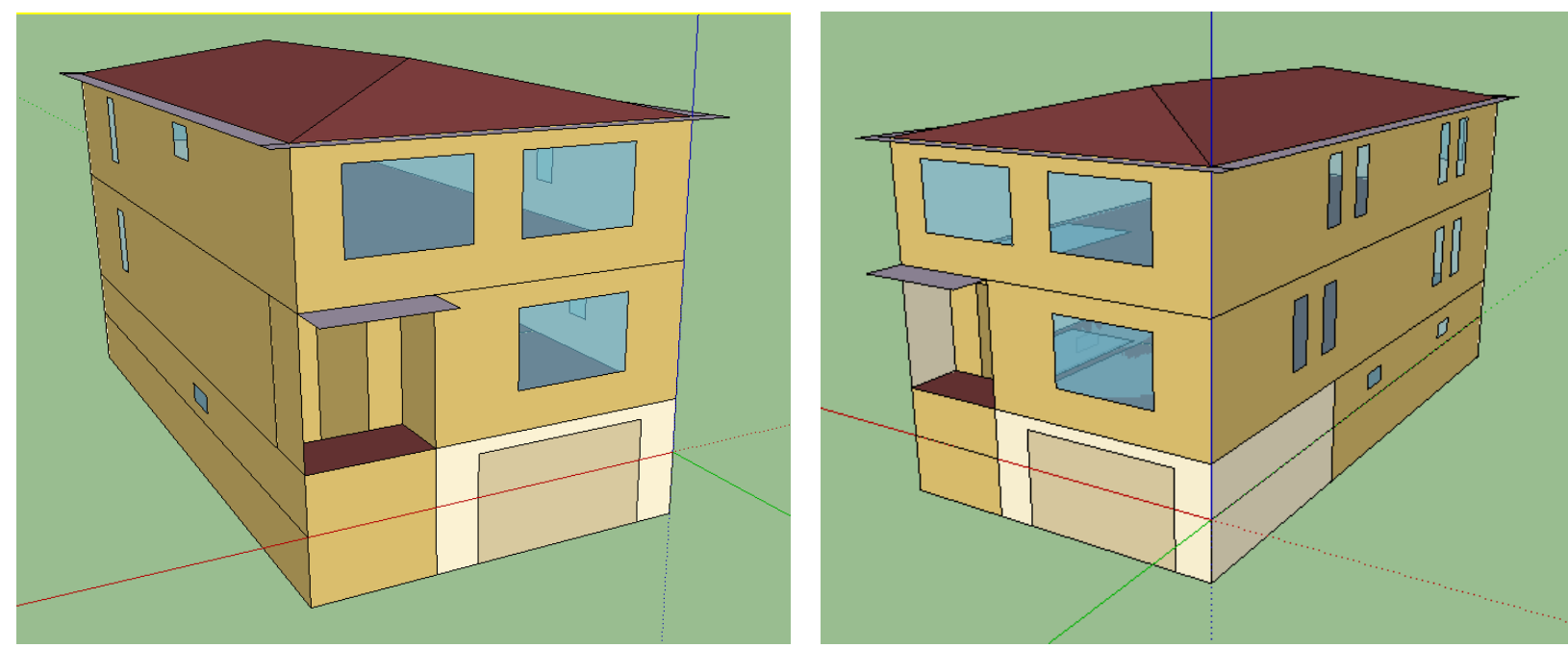

Figure 14: Geometry of 1970s OBC Single Detached House Baseline Energy Model 
1) The comparative analysis of baseline modeling result with Blaszak \& Richman (2013) is done based on total energy intensity and heating-cooling energy consumption:

Having energy intensity of $193 \mathrm{kWh} / \mathrm{m}^{2}$, the base case constituted a $23 \%$ difference with Blaszak \& Richman (2013)'s calculated energy intensity of $251 \mathrm{kWh} / \mathrm{m}^{2}$. It is also point-worthy that the average heated floor area of 1970s OBC detached house is found $261 \mathrm{~m}^{2}$ (from site survey) whereas Blaszak \& Richman (2013)'s finding was $216 \mathrm{~m}^{2}$. This result implies that even with a larger floor area, the baseline model provides lower energy intensity than what Blaszak \& Richman (2013) suggested. However, considering the heating-cooling load, the energy intensity $(161 \mathrm{kWh} / \mathrm{m} 2)$ of baseline model is $6 \%$ less than the calculated energy intensity $(172 \mathrm{kWh} / \mathrm{m} 2)$ of Blaszak \& Richman (2013).

An in-depth analysis of the survey results and methodology of baseline modeling suggests the following justifications for these variations with Blaszak \& Richman (2013)'s results:

- The modeling software and methodology of energy verification of this research is different than Blaszak \& Richman (2013) methodologies. In Blaszak \& Richman (2013), HOT2000 is used for energy simulation whereas this research used EnergyPlus as the principal energy modeling software. A difference in energy modeling output is not unexpected as EnergyPlus requires much more detailed data input compare to HOT2000. A major part of the data input is associated with direct data collection from field survey.

- The energy bills of four 1970 s OBC archetype houses have been collected to validate the baseline model. The validation was useful as the energy bills illustrate significantly lower monthly heating gas usage (see appendix E for energy bills) close to the baseline model result. As both baseline model result and energy bills are lower in terms of 
monthly energy consumption, it justifies the appropriateness of the baseline output even though significantly differs from Blaszak \& Richman (2013) results.

- As the heated floor area and some archetype features are different compare to what Blaszak \& Richman (2013) used, difference in energy intensity was expected. It is significant that Blaszak \& Richman (2013)'s 1970s OBC archetype is not characterized with semi-basement garage. From the survey of carefully selected neighbourhoods that mostly represent 1970s OBC archetype suggests that garage is an integral part of the lower level of both single and semi-detached houses of this period. From energy consumption perspective, this area works as a buffer unheated space which reduces direct heat loss through exterior walls. The insulated interzone surfaces and insulated exterior walls of garage helps to reduce direct heat loss from interior space to outdoor (figure 15). Moreover basement slab area and heat loss through ground surfaces are smaller because of garage slab position at that level.

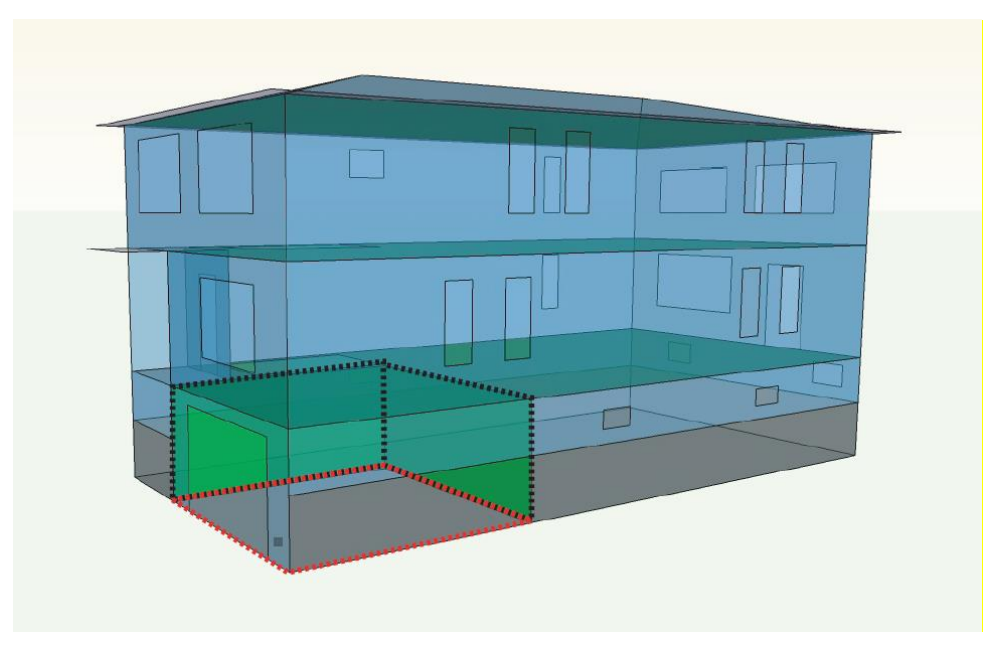

Figure 15: The Garage Space (Unheated Buffer Space) and Insulated Interzone Surfaces (Black Dots) and Garage Slab Incorporating to Reduce Heat Loss.

2) The baseline model total energy intensity is also analysed with CanmetENERGY Urban Archetypes Project in Clarington (NRC -CanmetENERGY, 2009) report. According to NRC -CanmetENERGY, (2009) report, total energy intensity of closest archetype of 
1970s single detached house is $265 \mathrm{kWh} / \mathrm{m}^{2}$ with a floor area of $191 \mathrm{~m}^{2}$ compare to 193 $\mathrm{kWh} / \mathrm{m}^{2}$ and $261 \mathrm{~m}^{2}$ of the baseline model respectively. This comparison shows $27 \%$ less overall energy intensity of base case comparing to NRC -CanmetENERGY (2009) result. There are a number of reasons why these variations can be happened. It is found that for NRC -CanmetENERGY (2009) project's heating system, hot water system, envelope parameters (e.g. foundation wall insulation) and occupants number are different than current research parameter selection. The major difference is that CanmetENERGY urban archetypes has incorporated electric baseboard heating and electric hot water system which consumes more energy than 1970s OBC forced air heating and gas hot water system.

\subsubsection{0s OBC Semi- Detached House Baseline Model and Validation}

Figure 16 shows the geometry of 1970s OBC semi-detached house utilizing Legacy OpenStudio - SketchUp Plugin. The EnergyPlus baseline input details for 1970s semi-detached house are shown in appendix D. EnergyPlus simulation outcome are below:
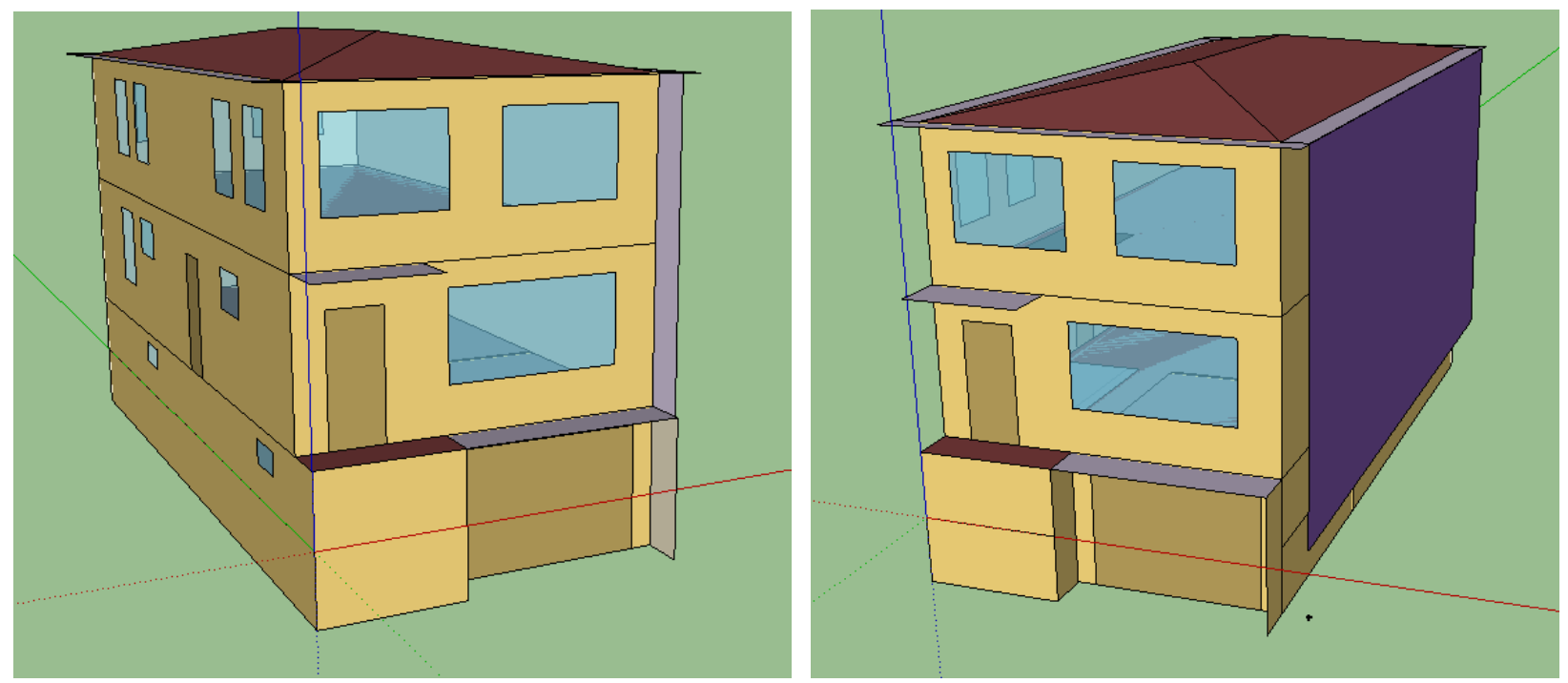

Figure 16: Geometry of 1970s OBC Semi-Detached House Baseline Energy Model 
The overall energy use for 1970 s OBC semi-detached house is $39,500 \mathrm{kWh} / \mathrm{year}$ and energy intensity is $176 \mathrm{kWh} / \mathrm{m}^{2}$. Considering heating and cooling load, the total energy use found is $31,944 \mathrm{kWh}$ and energy intensity is $143 \mathrm{kWh} / \mathrm{m}^{2}$ over one year period.

Blaszak \& Richman (2013) did not developed energy model for 1970s OBC semi-detached houses. Moreover, no semi-detached archetype energy investigation is found in Natural Resource Canada- CanmetENERGY (2009) to compare the achieved baseline result. It was expected that the energy use of semi-detached house will be less than detached house as heated floor area and exterior surfaces are smaller. In addition there is a shared wall between two units which reduces the heat loss compared to exterior wall.

Summary of baseline model result for 1970s OBC archetype houses are below:

Table 9: Summary of Baseline Model Result

\begin{tabular}{|l|l|l|l|l|}
\hline \multirow{2}{*}{ Archetype } & \multicolumn{3}{|l|}{ Total Energy Consumption } & \multicolumn{2}{l|}{ Heating and cooling load } \\
\cline { 2 - 5 } & $\begin{array}{l}\text { Energy Use } \\
(\mathrm{kWh})\end{array}$ & $\begin{array}{l}\text { Energy Intensity } \\
\left(\mathrm{kWh} / \mathrm{m}^{2}\right)\end{array}$ & $\begin{array}{l}\text { Energy Use } \\
(\mathrm{kWh})\end{array}$ & $\begin{array}{l}\text { Energy } \\
\text { Intensity } \\
\left(\mathrm{kWh} / \mathrm{m}^{2}\right)\end{array}$ \\
\hline $\begin{array}{l}\text { 1970s OBC } \\
\text { Detached House }\end{array}$ & 50,277 & 193 & 41,825 & 161 \\
\hline $\begin{array}{l}\text { 1970s OBC Semi- } \\
\text { Detached House }\end{array}$ & 39,500 & 176 & 31,944 & 143 \\
\hline
\end{tabular}

Overall, the energy intensity of 1970 s OBC houses is much lower than other archetypes (Century and War Time) houses calculated by Jermyn (2014), due to greater amount of insulation, airtightness following 1970s OBC code unlike other older houses. It is found that, as expected, the detached house has higher energy intensity than semi-detached house. The footprint of 1970s single detached and semi-detached houses are rectangle. But semi-detached homes have a smaller floor area than detached houses and because of shared wall between units, the heat loss is reduced. Moreover, semi-detached houses have a smaller surface area to 
volume ratio which results in less heat transfer through exterior wall. These results were expected.

\subsection{Calibration of the Baseline Energy models}

The baseline energy model has been validated following the calibration method of Jermyn (2014) to confirm the accuracy of the model. Generally, the energy model result over-predicts energy use compared to energy bill data (Jermyn D., 2014). This calibration is needed to adjust the simulation result with energy bills and develop a verified energy model.

The calibration method includes fine-tuning of baseline energy model and compares them with energy bill data. The steps of this process are:

1) There will be a normalization procedure of collected energy bills with heating degree days to avoid some discrepancy. Then normalized energy bills will be compared with base case model.

2) The base case energy model will be fine-tuned by changing variables such as envelope insulation, air infiltration $(\mathrm{ACH})$ and furnace efficiency to prepare it more close to normalized energy bill result.

According to ASHRAE 2007 guideline the monthly energy consumption should be modelled for one year period with corresponding weather data. This data should be compared with baseline energy data on monthly basis. In this research, Toronto weather file 2014 is used and energy model simulation is done for 2014 (one year period). Energy Bills hard copy of the year 2014 are collected for 1970s OBC archetype one detached and one semi-detached house for calibration of baseline energy model results. Houses are selected which more closely match with archetype features and HVAC system. In this research, one of the main requirements was selecting sample houses that are not altered by any renovation or addition. But because of limited participant interest to share their monthly energy bills, the collected bill for single 
detached house was limited to four and most of them are renovated by previous owners. Among the four energy bills, only one is collected with original hard copies of yearlong monthly bills. The other three were not considered because it was hard to verify their accuracy. Since the only selected bill has come from a previously renovated house, it is predicted that the energy usages will be lower than expected. One the other hand, three energy bills are collected from semidetached houses but no renovation has done for these houses. Among the three bills only one is selected for the same reason as single detached house. The collected energy bills data are attached in appendix E.

The major focus of this research is studying the heating and cooling load and achieving the target consumption. From collected energy bills it is not possible to find out cooling load from electricity bills. Only natural gas consumption for heating is employed for calibration. It is assumed that the gas consumption in summer month (June, July and August) is only for cooking and water heating which represents monthly non-heating baseline (Hubler, Tupper, \& Greensfelder, 2010). The average natural gas consumption of these three summer months is then deducted from each month to separate the gas usage for space heating. The overall natural gas consumption is then compared with the baseline energy model. To produce more accurate and practical results of the baseline model, it is fine-tuned by changing various parameters such as building envelope parameters, air infiltration and HVAC systems. The parameter changes also compared with the collected field survey data to avoid drastic changes. The baseline model is fine-tuned until statistical calibration target is achieved. There is similar calibration methodology cited in literatures for several examples (Hubler et al. 2010, Raftery et al. 2011, Yoon, Lee, \& Claridge 2003).

The natural gas billing does not necessarily reflect the actual monthly energy usage (Jermyn D., 2014). Enbridge specified that billing period may vary from 24 to 36 days (Enbridge Gas 
Distribution Inc., 2014). So collected monthly billing does not necessarily show the actual 30 day gas usage, and it will not be matched with baseline monthly gas consumption result.

To overcome this discrepancy, a normalization of energy bill data to heating degree day is executed. The heating degree day (HDD) of Toronto for 2014 is collected from weather data depot, and compared with both energy use of baseline energy model and energy bills.

\section{0s OBC Single Detached House Calibration}

Pre-calibration energy usage comparison for 1970 s detached house is as follows:

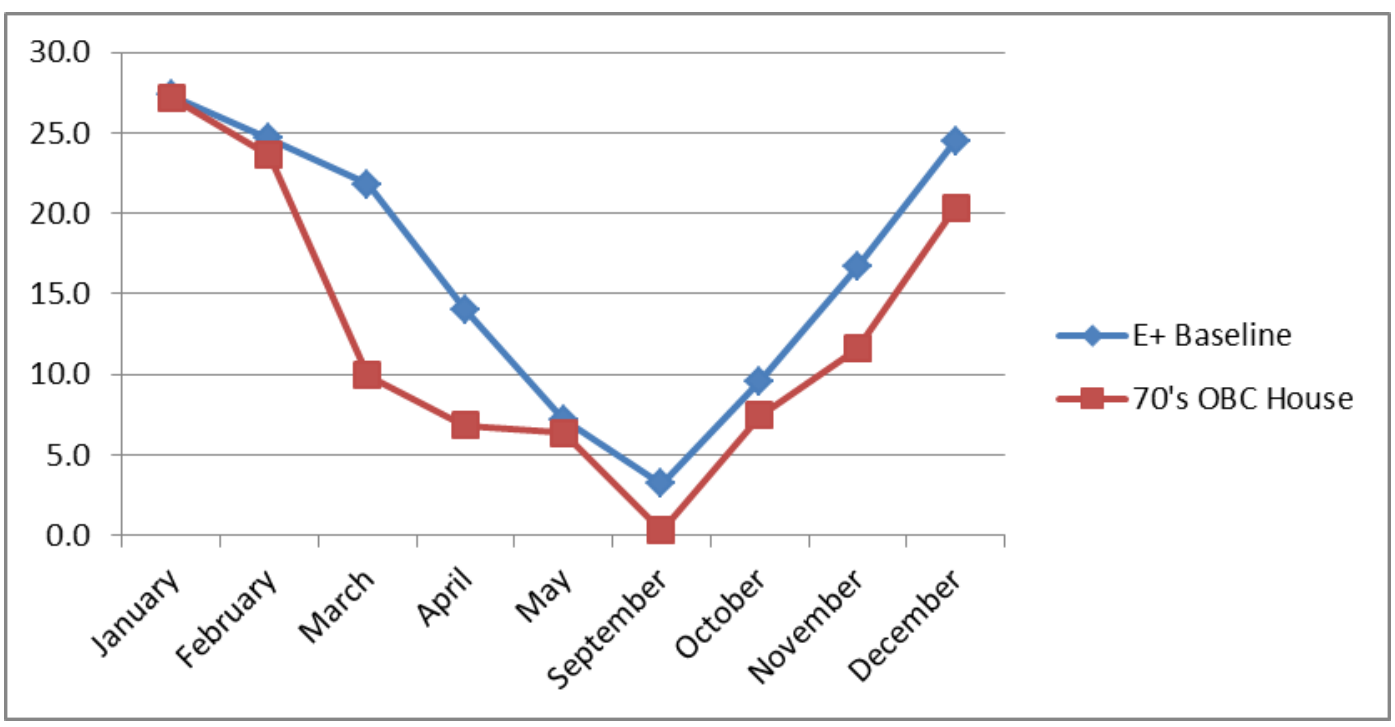

Figure 17: 1970s OBC Detached House Calibration: Energy Bill \& Energy Model (GJ)

- June, July and August are omitted as it is assumed in these summer months, the gas use is only for hot water \& cooking purpose and the average usage of summer months is deducted from other month as well

- The energy model over predicted the energy use for all 12 months of 2014

- As the sample house was majorly renovated the energy use is lower as predicted

- Energy bill showing radical difference in gas consumption on March and April of 2014. 
The second step of calibration includes normalization of energy bills in order to compare the energy use with heating degree day (HDD) of the year 2014.

Table 10: 1970s OBC Detached House Energy Bill (2014) Normalization

\begin{tabular}{|l|l|l|l|l|l|l|}
\hline & EnergyPlus & Energy Bill & $\begin{array}{l}\text { Heating } \\
\text { Degree } \\
\text { Days }\end{array}$ & $\begin{array}{l}\text { E+ } \\
\text { Baseline }\end{array}$ & Energy Bill & $\begin{array}{l}\text { Normalized } \\
\text { Energy Bill }\end{array}$ \\
\hline GJ & GJ & HDD (2014) & GJ/HDD & GJ/HDD & $\begin{array}{l}\text { Average } \\
\text { Energy Bill } \\
\text { GJ/HDD* HDD }\end{array}$ \\
\hline January & 27.3 & 27.2 & 822 & 0.0332 & 0.0331 & 22.55 \\
\hline February & 24.7 & 23.6 & 727 & 0.0339 & 0.0325 & 19.94 \\
\hline March & 21.8 & 9.9 & 683 & 0.0320 & 0.0145 & 18.73 \\
\hline April & 14.0 & 6.8 & 353 & 0.0398 & 0.0193 & 9.68 \\
\hline May & 7.2 & 6.4 & 132 & 0.0544 & 0.0484 & 3.62 \\
\hline September & 3.2 & 0.3 & 67 & 0.0478 & 0.0045 & 1.84 \\
\hline October & 9.6 & 7.4 & 223 & 0.0430 & 0.0334 & 6.12 \\
\hline November & 16.6 & 11.6 & 474 & 0.0351 & 0.0245 & 13.00 \\
\hline December & 24.5 & 20.3 & 552 & 0.0444 & 0.0368 & 15.14 \\
\hline Sum & 149.0 & 113.6 & Average & 0.0404 & 0.0274 & 110.63 \\
\hline
\end{tabular}

For normalization, the monthly energy usage from energy model is divided by monthly heating degree day (HDD) which provides a comparatively consistent usage per degree day (GJ/HDD).

The monthly energy usage from energy bills are also divided by monthly heating degree day (HDD) and produced a steady result. It is assumed that the gigajoule energy usage per heating degree day (GJ/HDD) should be constant for energy bills and the average value is calculated. Form table 10 it is found that for 1970s detached house the average energy bill GJ/HDD is 0.0274. This average value is then multiplied by monthly heating degree day (HDD) to determine the normalized energy bill. The purpose of this normalization is to remove the varying time component from energy bill, to prepare the energy usage per heating degree day and to align with month (Jermyn D., 2014).

Figure 18 represents the energy usage comparison of energy model and normalized energy bill data. The figure illustrates- 


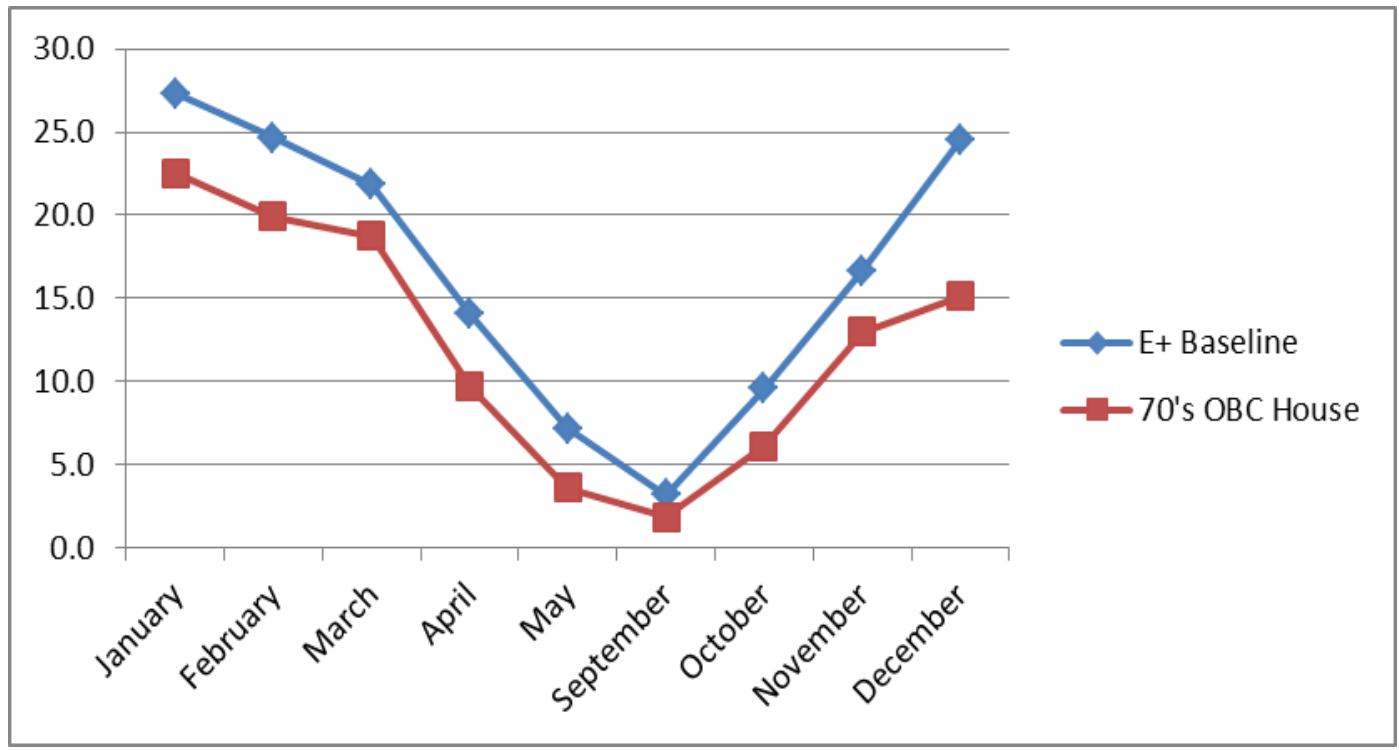

Figure 18: 1970s OBC Detached House Calibration: Normalized Energy Bill \& Energy Model (GJ)

- After normalization, the energy bill data demonstrates significantly less drastic monthly fluctuations.

- The normalization process of energy bills providing equalizing distribution of energy uses according to heating degree day (HDD) over one year period (2014).

- The radical consumption on March and April changed after normalization.

The third step of energy model calibration includes fine tuning the baseline energy model by changing some input of model. The change of variables in energy model includes upgrading the envelope insulation and air infiltration $(\mathrm{ACH})$. Insulation is increased in walls from $64 \mathrm{~mm}$ to $130 \mathrm{~mm}$ and in roof from $184 \mathrm{~mm}$ to $250 \mathrm{~mm}$. This increased insulation is still within the average ranges given by Blaszak (2010). Here $64 \mathrm{~mm}$ fibreglass wall insulation for baseline model is adapted from Blaszak \& Richman (2013)'s given RSI 1.71, which differs from EcoENERGY database RSI 1.95 (89mm fibreglass insulation) for 1970s OBC archetype. In order to make a comparison RSI 1.71 is implemented in baseline model even though EcoENERGY database indicated that the value should be RSI 1.95. For fine tuning air tightness is increased within the 
tolerances of the LBL N-Factor (15 cfm of natural air exchange) and in normal pressure 0.225 $\mathrm{ACH}$ is adapted to fine tune the baseline model.

Figure 19 illustrates the calibration of energy usages of fine-tuned energy model and normalized energy bills for 1970s OBC single detached house.

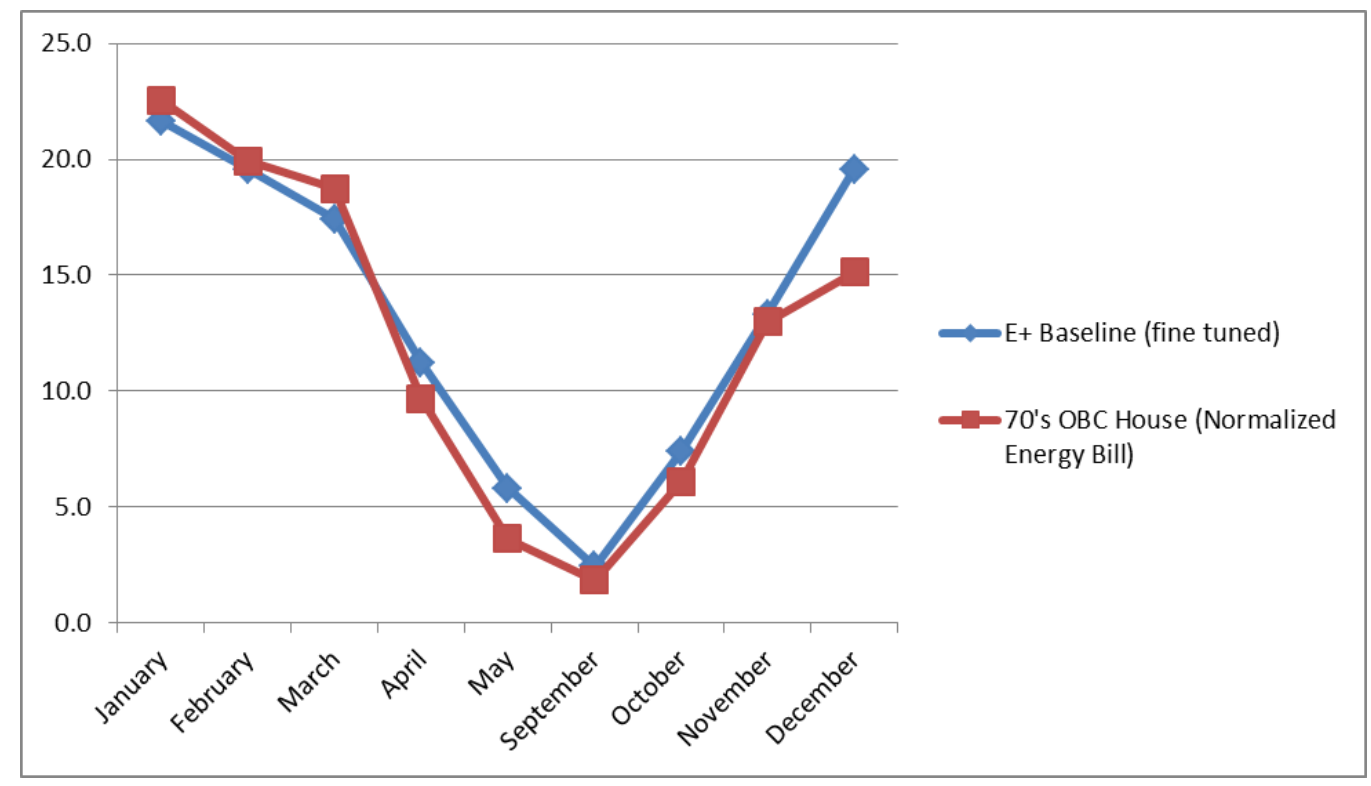

Figure 19: 1970s OBC Detached House Calibration: Normalized Energy Bill \& Fine Tuned Energy Model (GJ)

After fine tuning the model, energy usage difference of energy model and energy bill appears less and almost aligned to each other. This means the calibration can be achieved by fine tuning variables in baseline energy model. Although there are still slight over predictions and under predictions in the energy model, it is negligible because most of the months are almost aligned with energy bill.

\section{0s OBC Semi Detached House Calibration}

Pre-calibration energy usage comparison for 1970 s semi-detached house is as follows: 


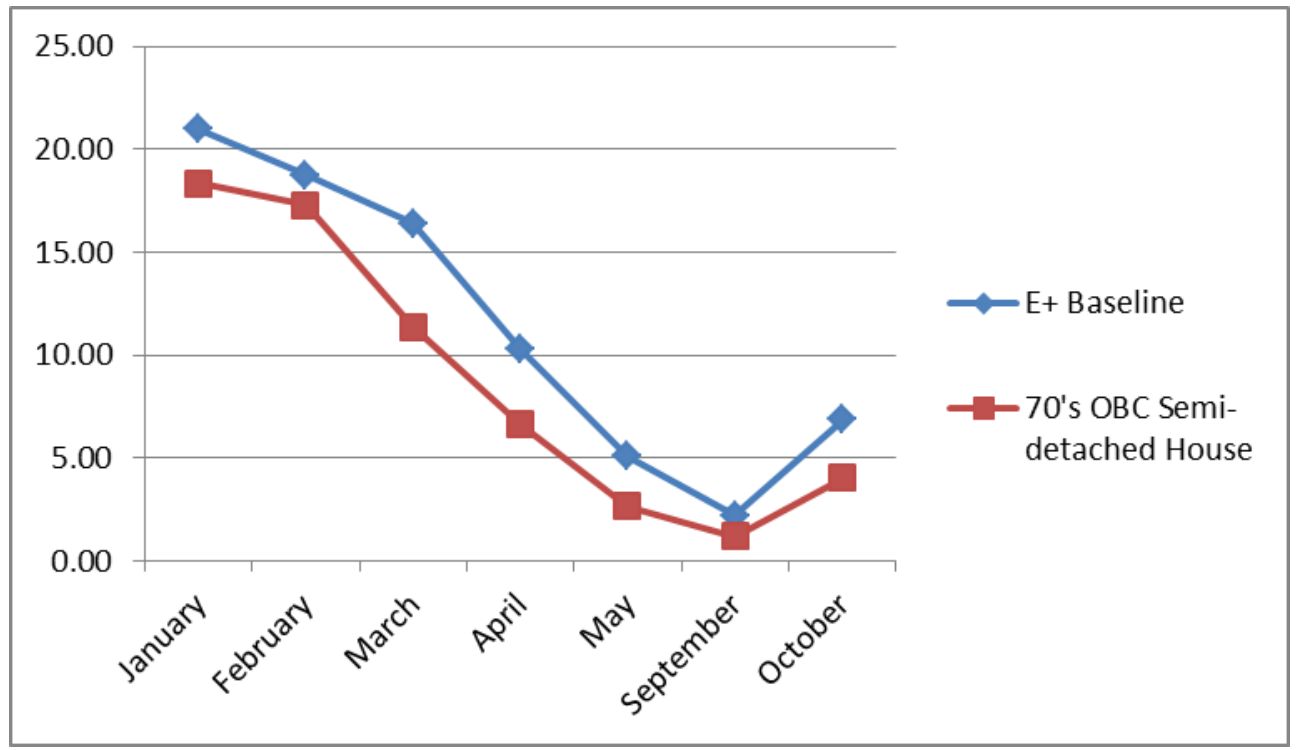

Figure 20: 1970s OBC Semi-Detached House Calibration: Energy Bill \& Energy Model (GJ)

- Three summer month June, July and August are omitted

- $\quad$ The energy model over predicted the energy use for all shown months of 2014

- The energy bill data for missing months are omitted from calculation (November \& December).

In the second step of calibration semi-detached house followed the same process as detached house to normalize the energy bills with heating degree day (HDD) for year 2014.

Table 11: 1970s OBC Semi-Detached House Energy Bill (2014) Normalization

\begin{tabular}{|l|l|l|l|l|l|l|}
\hline & EnergyPlus & $\begin{array}{l}\text { Energy } \\
\text { Bill }\end{array}$ & $\begin{array}{l}\text { Heating } \\
\text { Degree Days }\end{array}$ & $\begin{array}{l}\text { E+ } \\
\text { Baseline }\end{array}$ & Energy Bill & $\begin{array}{l}\text { Normalized } \\
\text { Energy Bill }\end{array}$ \\
\hline & GJ & GJ & HDD (2014) & GJ/HDD & GJ/HDD & $\begin{array}{l}\text { Average } \\
\text { Energy Bill } \\
\text { GJ/HDD* HDD }\end{array}$ \\
\hline January & 20.97 & 18.3 & 822 & 0.0255 & 0.0223 & 16.14 \\
\hline February & 18.75 & 17.3 & 727 & 0.0258 & 0.0238 & 14.27 \\
\hline March & 16.38 & 11.4 & 683 & 0.0240 & 0.0167 & 13.41 \\
\hline April & 10.27 & 6.6 & 353 & 0.0291 & 0.0188 & 6.93 \\
\hline May & 5.09 & 2.6 & 132 & 0.0386 & 0.0200 & 2.59 \\
\hline September & 2.20 & 1.2 & 67 & 0.0328 & 0.0178 & 0.02 \\
\hline October & 6.86 & 4.0 & 223 & 0.0308 & 0.0181 & 4.38 \\
\hline Sum & 80.53 & 61.5 & Average & 0.0295 & 0.0196 & \\
\hline
\end{tabular}


In normalization process energy model monthly data and energy bills are divided by monthly heating degree day (HDD). The normalization calculation for 1970s OBC semi-detached house is shown in table 11. It is found that the average energy bill GJ/HDD is 0.0196 . Normalized monthly energy bills are calculated for semi-detached house.

Figure 21 represents the energy usage comparison of energy model and normalized energy bill data.

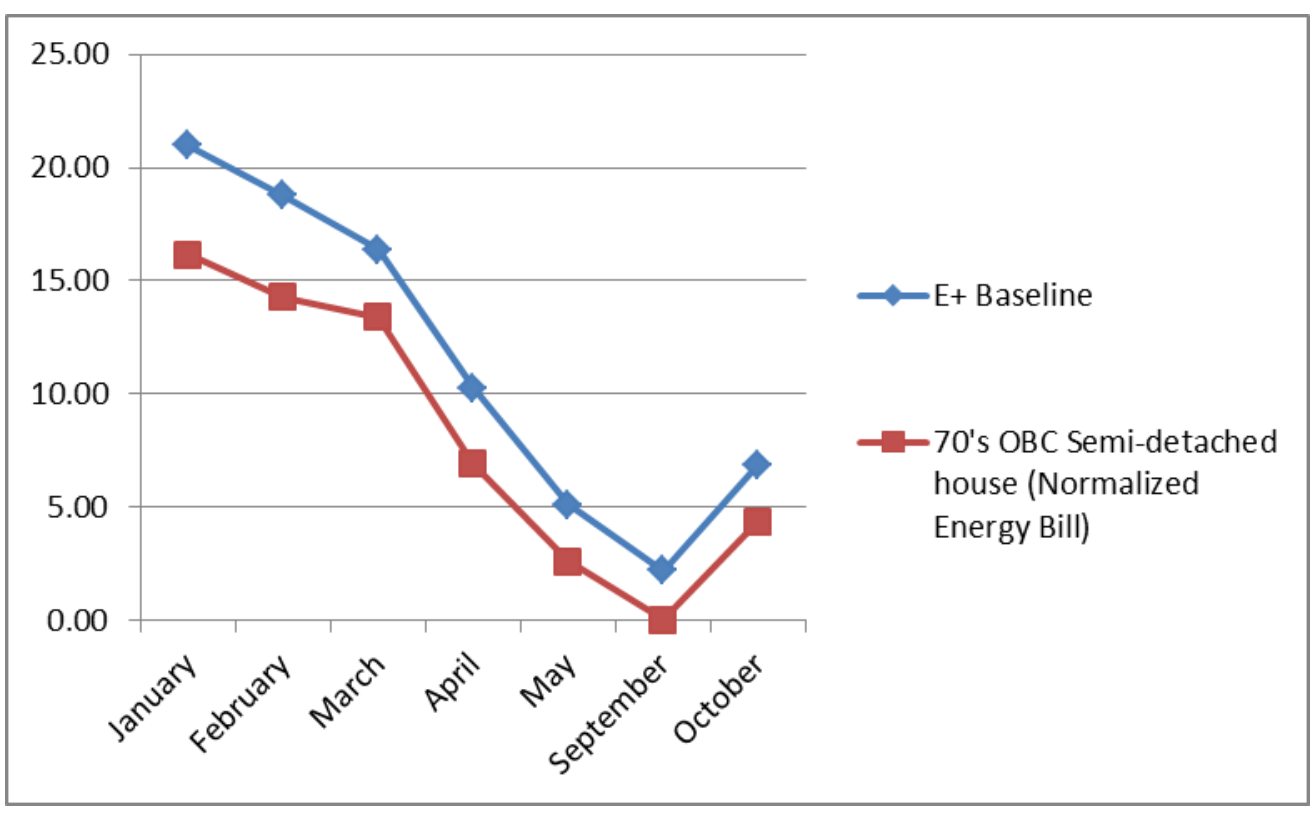

Figure 21: 1970s OBC Semi-Detached House Calibration: Energy Bill \& Energy Model (GJ)

- An equalizing distribution of energy bills received by the normalization process of semidetached house.

Fine tuning of baseline energy model includes change of some variables in model which are increase of envelope insulation and air infiltration reduction. Insulation is increased in walls from $64 \mathrm{~mm}$ to $130 \mathrm{~mm}$ and in roof from $184 \mathrm{~mm}$ to $250 \mathrm{~mm}$. This is still within the average insulation retrofit ranges given by Blaszak (2010). Air tightness was increased within the tolerances of the LBL N-Factor ( $15 \mathrm{cfm}$ of natural air exchange) and in normal pressure 0.25 
$\mathrm{ACH}$ is adapted. Figure 22 shows the comparison of energy usage of fine-tuned baseline model and normalized energy bills which reflects close alignment of energy usage.

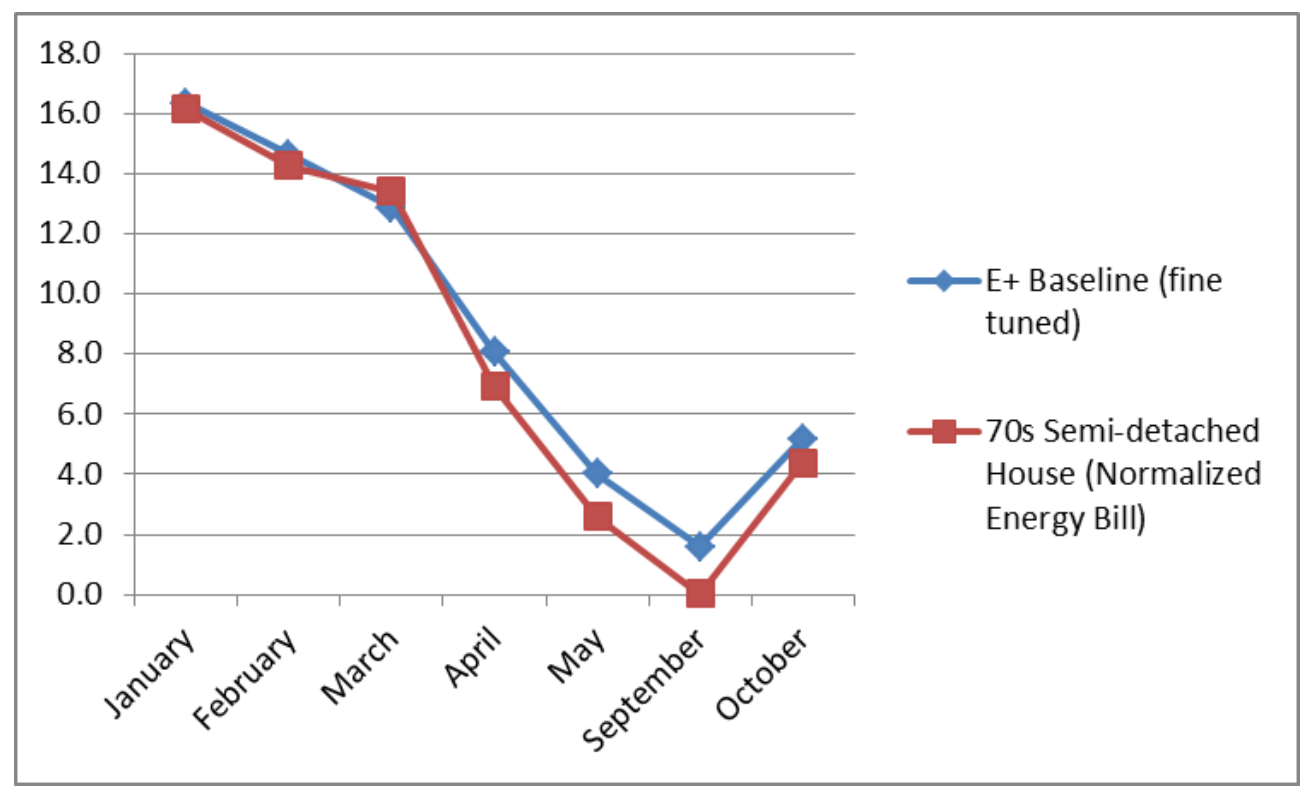

Figure 22: 1970s OBC Semi-Detached House Calibration: Normalized Energy Bill \& Fine Tuned Energy Model (GJ)

The calibration is useful as the process allowed each homes to be calibrated with corresponding baseline energy model by altering few inclusive parameters such as envelope insulation and airtightness. It has also been observed in field survey that most of the detached houses were already renovated by current or previous owner and it is expected that inspected 1970s houses should perform better than original 1970s construction. In this research the baseline models are characterized with an average representation of archetype houses with typical insulation and air tightness values. These parameters can differ home to home and therefore it is reasonable to alter these parameters marginally to calibrate the energy model with actual energy bills.

From above calibration result it is proven that the prepared baseline model energy usage for detached and semi-detached archetypes can be merged with actual sample house energy bills by making some minor alteration of building parameters. The objective of this research is to model the typical archetype house with parameters mentioned in table 8 . The calibration 
process is to validate that typical energy usage from archetype model can be merged with practical energy bill data which rationalize the correctness of the archetype model. In this research the energy bill is not used to revise the energy model except for validation because the energy bill does not represent an average value which is the case for baseline model. Energy bill can vary between the houses. Moreover, most of the 1970 s houses are already been renovated and it is expected that the energy bills will illustrated less energy usage than what it supposed to be without any renovations. Therefore the original baseline model for 1970 s detached and semi-detached house developed in this study are carried forward for retrofitting.

The final baseline energy use and intensity of archetype houses for heating and cooling load are summarized below:

Table 12: Final Baseline Energy Use and Intensity of Archetype Houses for Heating and Cooling Load

\begin{tabular}{|l|l|l|}
\hline Archetype & Energy Use $(\mathrm{kWh})$ & Energy Intensity $\left(\mathrm{kWh} / \mathrm{m}^{2}\right)$ \\
\hline 1970s OBC Detached House & 41,825 & 161 \\
\hline $\begin{array}{l}\text { 1970s OBC Semi-Detached } \\
\text { House }\end{array}$ & 31,944 & 143 \\
\hline
\end{tabular}

\section{Phase 3- Retrofitting Strategies:}

In retrofitting phase the baseline model is upgraded utilizing high performance strategy to achieve target energy intensity for 1970s OBC houses. The target requirement for heating cooling load is $75 \mathrm{kWh} / \mathrm{m}^{2}$. This study focuses on building envelope and HVAC retrofit which significantly impact on energy use of the house. Building envelope retrofit includes increasing roof, wall, foundation wall and slab insulation including air sealing and changing door and window. HVAC retrofit includes installing high efficiency furnaces.

Eight separate strategies (Jermyn, 2014) have been considered for high performance retrofitting which are mentioned below: 
Table 13: Retrofitting Strategy for 1970 s OBC Houses

\begin{tabular}{|l|l|}
\hline Retrofit elements & Retrofit strategies \\
\hline Wall insulation & Increase insulation level/R value \\
\hline Roof insulation & Increase insulation level/R value \\
\hline Foundation wall insulation & Increase insulation level/R value \\
\hline Slab insulation & Increase insulation level/R value \\
\hline Windows & $\begin{array}{l}\text { Add more glass layer/increase } \mathrm{R} \text { value, } \\
\text { adding surface coat or altering the gas } \\
\text { mixture in the glazing units. }\end{array}$ \\
\hline Air sealing & $\begin{array}{l}\text { Increase air tightness by sealing } \\
\text { penetrations and air leakage paths. }\end{array}$ \\
\hline Heating and cooling & Increasing furnace efficiency \\
\hline Ventilation & $\begin{array}{l}\text { Installing heat recovery or energy } \\
\text { recovery ventilators of various efficiencies. }\end{array}$ \\
\hline
\end{tabular}

It is found in survey that most of the houses replaced the door with newer insulated door. Therefore, retrofitting the door is not considered in this research study. Three levels of guidelines have been adapted for retrofitting using these eight measures. The methodology is adapted from Jermyn (2014) as a continuation of his research project. These levels are specified below:

Table 14: Retrofitting Guideline for Building Envelope System of 1970s OBC Houses

\begin{tabular}{|l|l|}
\hline Levels of Retrofit & Retrofitting guideline \\
\hline Level 1 & $\begin{array}{l}\text { Follows increase of insulation specified in the } \\
\text { regulation of 2012 Ontario Building Code } \\
\text { (OBC 2012). }\end{array}$ \\
\hline Level 2 & $\begin{array}{l}\text { Follows high performance assemblies } \\
\text { developed by Mucciarone (2011) }\end{array}$ \\
\hline Level 3 & $\begin{array}{l}\text { Includes RSI enclosure recommendations for } \\
\text { Toronto's climate zone published by the } \\
\text { Building Science Corporation (Straube 2011, } \\
\text { Straube \& Grin 2010). }\end{array}$ \\
\hline
\end{tabular}


These three levels are offering high performance retrofitting options to upgrade energy performance. The wall, roof, foundation wall, and slab insulation are taken from all three levels. OBC 2012, SB 12 is utilized to determine the retrofitting level 1 parameter which is attached in appendix F. From SB-12, climate zone 1 and Space Heating Equipment with AFUE 90\% are selected to determine retrofit and compliance package $G$ is chosen. Mucciarone (2011) in his research paper proposed high levels retrofit for sustainable renovation of building envelope assembles which is designated for level 2. Level 3 retrofit for building envelope assembles is selected from John Straube (2011)'s suggested high RSI value enclosures for high performance residential building. These three levels of retrofit are selected to verify the energy performance of 1970 s OBC houses from minimum current building code option to high level building science specialist suggestions to achieve high energy performance of residential houses. The detail parameters of these retrofit levels are as below:

Table 15: Detail Parameters of Retrofitting Levels

\begin{tabular}{|c|c|c|c|c|}
\hline Strategy & Baseline & Level 1 & Level 2 & Level 3 \\
\hline Walls (RSI) & 1.71 (R-9.71) & 4 & 6 & 10 \\
\hline Roof (RSI) & $4.18(\mathrm{R}-23.74)$ & 9 & 10.5 & 13 \\
\hline Basement Walls (RSI) & $1.16(\mathrm{R}-6.59)$ & 2 & 3 & 3.5 \\
\hline Slab (RSI) & 0.058 & 0.75 & 1 & 1.75 \\
\hline Windows (U-factor) & 2.7 & 1.9 & 1.2 & 1 \\
\hline $\begin{array}{l}\text { Air Sealing (ACH at } 50 \\
\mathrm{~Pa} \text { ) }\end{array}$ & 5.75 & $\begin{array}{l}15 \% \text { reduction } \\
(4.88)\end{array}$ & 2 & 1 \\
\hline Heating and Cooling & $80 \%$ efficient & $90 \%$ efficient & 94\% efficient & 97\% efficient \\
\hline Ventilation & $\mathrm{N} / \mathrm{A}$ & $\begin{array}{l}60 \% \text { efficient } \\
\text { HRV }\end{array}$ & $\begin{array}{l}\text { 85\% efficient } \\
\text { HRV }\end{array}$ & $\begin{array}{l}80 \% \text { efficient } \\
\text { ERV }\end{array}$ \\
\hline
\end{tabular}

The heating and cooling retrofits represent conventional, medium, and high efficiency levels which are represented by Energy Star certified products (Jermyn D., 2014). Window retrofit levels are chosen from standard glazing system constructions given in WINDOW 7 software program database (LBNL, 2014 cited in Jermyn D., 2014). Here air sealing includes sealing all 
door window frames, outlet and switches, chimney flashing, all ducts, plumbing and utility access, water and furnace flues, sill plates, attic entrance etc. The air sealing techniques includes caulking, weather stripping and use of gaskets. It is assumed that the lowest ACH level 3 can be achieved only when both wall and roof retrofit will be undertaken in retrofit process.

The wall retrofit considered replacement of interior insulation and addition of newer one to meet the target RSI. New $50 \times 75 \mathrm{~mm}$ wood frame should be added with existing wood frame wall structure to add new insulation. Interior replacement is considered to avoid the challenge and restrictions on side yard setback. There are some losses of interior space in retrofitting at different floor levels but this issue is not considered significant in this research. The slab insulation is added on top of existing $75 \mathrm{~mm}$ concrete. As a result, there is no need of removing existing slab structure. Increasing roof insulation is simple than other aspects of building envelope. The insulation of attic ceiling will be increased according to the RSI demand. The building envelope assembles for all three retrofit levels are shown in appendix G. All these assembles are taken from Jermyn's (2014) retrofit assembles for wood frame structure house. 1970s OBC houses are wood frame structure and the baseline envelope assembles are similar to war time wood frame structure houses. As a continuation of Jermyn (2014) research, the suggested retrofit assembles for War Time houses are adopted for 1970s houses. The hygrothermal analysis result for these retrofit levels are given in appendix $H$. There are no condensations or decay possibility considered throughout the year for different level of retrofit assemblies.

\subsection{Energy performance \& Retrofitted Energy Model Result}

The high performance three levels of retrofits are performed successfully with EnergyPlus software for 1970s OBC archetype houses. Three levels of retrofitting parameters are entered in software separately for detached and semi-detached house and investigated the energy uses. The results are given in table $16 \& 17$ which illustrates the energy intensity of heating and 
cooling load for all three levels of detached and semi-detached retrofitted houses achieved less than $75 \mathrm{kWh} / \mathrm{m}^{2}$. Even at level 3 of semi-detached house, the energy intensity found $27 \mathrm{kWh} / \mathrm{m}^{2}$ which is close to EnerPHit standard $\left(25 \mathrm{kWh} / \mathrm{m}^{2}\right.$ for heating and cooling energy intensity). When all essential building envelope measures and HVAC system improved overall with high performance upgrading the energy intensity target $\left(75 \mathrm{kWh} / \mathrm{m}^{2}\right)$ received effortlessly.

It is also examined that in case of 1970 s houses the exterior wall and basement slab are the greatest source of heat loss and window and ventilation are less priority for retrofitting. Basement wall and roof heat loss are same in scale. Blaszak and Richman (2013) found wall and window as great heat loss source and roof as less priority retrofit for 1970 s houses. This difference can be attributed due to difference of archetype features and methodology of modelling as this research utilized EnergyPlus software and Blaszak and Richman (2013) used HOT2000 software.

The research target achievement is successful for three separate levels of retrofitting. Table 16 \& 17 demonstrates the result for detached and semi-detached houses comparing to original baseline model result-

Table 16: High Performance Retrofit Result for 1970s Detached House

\begin{tabular}{|l|l|l|l|l|}
\hline & \multicolumn{3}{|l|}{ Retrofitted Model Results } \\
\hline $\begin{array}{l}\text { 1970s OBC Single } \\
\text { Detached Archetype }\end{array}$ & $\begin{array}{l}\text { Baseline Model } \\
\text { Result }\end{array}$ & Level 1 & Level 2 & Level 3 \\
\hline $\begin{array}{l}\text { Total Energy Use (kWh) } \\
\text { (Heating and Cooling) }\end{array}$ & 41,825 & 16,419 & 11,002 & 8,763 \\
\hline $\begin{array}{l}\text { Energy Intensity } \\
\left(\mathrm{kWh} / \mathrm{m}^{2}\right) \\
(\text { Heating and Cooling) }\end{array}$ & 161 & 63 & 42 & 34 \\
\hline
\end{tabular}


Table 17: High Performance Retrofit Result for 1970s Semi-Detached House

\begin{tabular}{|l|l|l|l|l|}
\hline & \multicolumn{3}{|l|}{ Retrofitted Model Results } \\
\hline $\begin{array}{l}\text { 1970s OBC Semi- } \\
\text { Detached Archetype }\end{array}$ & $\begin{array}{l}\text { Baseline Model } \\
\text { Result }\end{array}$ & Level 1 & Level 2 & Level 3 \\
\hline $\begin{array}{l}\text { Total Energy Use (kWh) } \\
\text { (Heating and Cooling) }\end{array}$ & 31,944 & 11,841 & 7,013 & 6,058 \\
\hline $\begin{array}{l}\text { Energy Intensity } \\
\left.\text { (kWh/m }{ }^{2}\right) \\
\text { (Heating and Cooling) }\end{array}$ & 143 & 53 & 31 & 27 \\
\hline
\end{tabular}

In this stage of research, the question arises regarding how viable these retrofitting levels are in terms of the user's viewpoint. Economic efficiency of incorporating energy saving measures should be more desirable for consumers. The next steps of research constitute cost efficiency evaluation for high performance retrofitting for target energy intensity and establish an approximate economic feasibility.

\subsection{Feasibility of high performance retrofitting:}

Retrofitting cost analysis and performance of various retrofit levels have been evaluated in this phase to investigate the viability of retrofitting of 1970 s OBC archetypes. Cost is an important factor from user's perspective to identify the best scenario of retrofit levels. Therefore the retrofit analysis explored both the most cost effective retrofit option and highest performance to meet the $75 \mathrm{kWh} / \mathrm{m}^{2}$ target. To perform this analysis, two steps have been followed:

1) Retrofit Cost Analysis: Retrofit cost analysis is the calculation of cost involved to implement retrofitting for saving energy consumptions. Parameters from the baseline model were utilized to calculate the average total area of windows, basement wall, slab, above grade wall and roof for cost estimation as showed in table 18. Unit cost for retrofitting these elements of 1970 s OBC houses have been collected from Jermyn's (2014) data of retrofitting cost for War-Time house (wood structure house). For 1970s house, the proposed three retrofitting assembles are similar 
to War Time retrofitting options. Jermyn (2014) collected the costing data from 3 contractors and produced an average costing that is used for this cost analysis. The unit and capital cost details are given in appendix $\mathrm{I}$.

Table 18: Average Areas of 1970s OBC Detached \& Semi-Detached House

\begin{tabular}{|l|l|l|l|l|l|}
\hline & $\begin{array}{l}\text { Windows } \\
\left(\mathrm{m}^{2}\right)\end{array}$ & $\begin{array}{l}\text { Basement } \\
\left(\mathrm{m}^{2}\right)\end{array}$ & $\begin{array}{l}\text { Slabs } \\
\left(\mathrm{m}^{2}\right)\end{array}$ & $\begin{array}{l}\text { Walls } \\
\left(\mathrm{m}^{2}\right)\end{array}$ & $\begin{array}{l}\text { Roof } \\
\left(\mathrm{m}^{2}\right)\end{array}$ \\
\hline $\begin{array}{l}\text { 1970s Single Detached } \\
\text { House }\end{array}$ & 31.15 & 46.19 & 76.24 & 282 & 115.5 \\
\hline $\begin{array}{l}\text { 1970s Semi-Detached } \\
\text { House }\end{array}$ & 28.88 & 38.11 & 55.72 & 211 & 81.74 \\
\hline
\end{tabular}

Each retrofit element has been analysed by energy modeling in three levels, and corresponding energy intensity savings have been noted. This allows identifying the lowest cost options for highest energy intensity saving for each element in three levels (table $19 \& 20$ ). The result helps to prioritise the retrofit opportunities for different elements based on both energy intensity saving and cost. This ensured that the selected retrofit strategy not only provides a reduction in energy use, but also demonstrates the most attractive cost/benefit. For example, in table $19 \& 20$, for level-1 retrofit of heating and cooling is considered as the highest in priority to retrofit because of lowest cost per saved energy intensity with significant overall energy intensity saving. Basement slab also has lower cost per saved energy intensity, and higher energy intensity saving and selected as second in priority for retrofitting. On the other hand, although an exterior wall above grade has highest energy intensity saving, it was not been placed among the higher priority because of its high cost. That cost-benefit analysis results in priority-based retrofitting in three levels for all retrofit elements. 
Table 19: Retrofit Cost Analysis Considering Energy Intensity Savings for Individual Parameters (Detached House)

\begin{tabular}{|c|c|c|c|c|c|c|c|c|c|c|c|c|}
\hline $\begin{array}{l}\text { Baseline } \\
161(\mathrm{kWh} \\
\left./ \mathrm{m}^{2}\right)\end{array}$ & Level 1 & & & & Level 2 & & & & Level 3 & & & \\
\hline Retrofit & $\begin{array}{l}\text { Intensit } \\
\mathrm{y} \\
(\mathrm{kWh} / \\
\left.\mathrm{m}^{2}\right)\end{array}$ & $\begin{array}{l}\text { Save } \\
\mathrm{d} \\
(\mathrm{kWh} \\
\left./ \mathrm{m}^{2}\right)\end{array}$ & Cost & $\begin{array}{l}\$ / \text { Sav } \\
\text { ed }\end{array}$ & $\begin{array}{l}\text { Intensit } \\
\mathrm{y} \\
(\mathrm{kWh} / \mathrm{m} \\
\left.{ }^{2}\right)\end{array}$ & $\begin{array}{l}\text { Saved } \\
(\mathrm{kWh} / \\
\left.\mathrm{m}^{2}\right)\end{array}$ & Cost & $\begin{array}{l}\text { \$/Save } \\
\mathrm{d}\end{array}$ & $\begin{array}{l}\text { Intensit } \\
\mathrm{y} \\
(\mathrm{kWh} / \\
\left.\mathrm{m}^{2}\right)\end{array}$ & $\begin{array}{l}\text { Saved } \\
(\mathrm{kWh} / \\
\left.\mathrm{m}^{2}\right)\end{array}$ & Cost & $\begin{array}{l}\text { \$/Save } \\
d\end{array}$ \\
\hline $\begin{array}{l}\text { Heating/ } \\
\text { Cooling }\end{array}$ & 143 & 18 & 3,150 & 175 & 136 & 25 & 3,665 & 147 & 132 & 29 & 4,333 & 149 \\
\hline Slabs & 138 & 23 & 4,950 & 215 & 136 & 25 & 5,225 & 209 & 133 & 28 & 5,395 & 193 \\
\hline Roof & 155 & 6 & 1,974 & 329 & 154 & 8 & 2,250 & 281 & 153 & 8 & 2,726 & 341 \\
\hline $\begin{array}{l}\text { Basemen } \\
\text { t Walls }\end{array}$ & 153 & 8 & 3,461 & 433 & 152 & 9 & 3,585 & 398 & 152 & 9 & 3,681 & 409 \\
\hline $\begin{array}{l}\text { Air } \\
\text { Sealing }\end{array}$ & 159 & 2 & 1,182 & 591 & 152 & 9 & 1,500 & 167 & 149 & 12 & 1,500 & 125 \\
\hline $\begin{array}{l}\text { Ventilatio } \\
\mathrm{n}\end{array}$ & 155 & 6 & 2,125 & 354 & 154 & 7 & 3,256 & 465 & 155 & 6 & 3,726 & 621 \\
\hline Walls & 121 & 40 & 27,418 & 685 & 112 & 49 & 33,821 & 690 & 109 & 52 & 36,175 & 696 \\
\hline Windows & 152 & 9 & 26,016 & 2,891 & 151 & 10 & 28,896 & 2,890 & 149 & 12 & 34,079 & 2,840 \\
\hline
\end{tabular}

Table 20: Retrofit Cost Analysis Considering Energy Intensity Savings for individual Parameters (Semi-Detached House)

\begin{tabular}{|c|c|c|c|c|c|c|c|c|c|c|c|c|}
\hline $\begin{array}{l}\text { Baselin } \\
\text { e } \\
143(\mathrm{k} \\
\left.\mathrm{Wh} / \mathrm{m}^{2}\right)\end{array}$ & Level 1 & & & & Level 2 & & & & Level 3 & & & \\
\hline Retrofit & $\begin{array}{l}\text { Intensit } \\
\mathrm{y} \\
(\mathrm{kWh} / \\
\left.\mathrm{m}^{2}\right)\end{array}$ & $\begin{array}{l}\text { Saved } \\
(\mathrm{kWh} / \\
\left.\mathrm{m}^{2}\right)\end{array}$ & Cost & $\begin{array}{l}\text { \$ } \\
\text { /Save } \\
\text { d }\end{array}$ & $\begin{array}{l}\text { Intensity } \\
\text { (kWh/m } \\
\left.{ }^{2}\right)\end{array}$ & $\begin{array}{l}\text { Saved } \\
(\mathrm{kWh} / \\
\left.\mathrm{m}^{2}\right)\end{array}$ & Cost & $\begin{array}{l}\text { \$/Save } \\
\text { d }\end{array}$ & $\begin{array}{l}\text { Intensit } \\
\mathrm{y} \\
(\mathrm{kWh} / \\
\left.\mathrm{m}^{2}\right)\end{array}$ & $\begin{array}{l}\text { Saved } \\
(\mathrm{kWh} / \\
\left.\mathrm{m}^{2}\right)\end{array}$ & Cost & $\begin{array}{l}\$ / \text { Save } \\
\mathrm{d}\end{array}$ \\
\hline $\begin{array}{l}\text { Heatin } \\
\text { g/Cooli } \\
\text { ng }\end{array}$ & 126 & 17 & 3,150 & 185 & 122 & 21 & 3,665 & 175 & 118 & 25 & 4,333 & 173 \\
\hline Slabs & 125 & 18 & 3,618 & 201 & 124 & 19 & 3,810 & 201 & 120 & 23 & 3,934 & 171 \\
\hline Roof & 138 & 5 & 1,397 & 279 & 137 & 6 & 1,593 & 265 & 136 & 7 & 1,929 & 276 \\
\hline $\begin{array}{l}\text { Basem } \\
\text { ent } \\
\text { Walls }\end{array}$ & 135 & 8 & 2,856 & 357 & 134 & 9 & 2,958 & 329 & 133 & 10 & 3,037 & 304 \\
\hline $\begin{array}{l}\text { Air } \\
\text { Sealing }\end{array}$ & 141 & 2 & 1,182 & 591 & 135 & 8 & 1,500 & 188 & 133 & 10 & 1,500 & 150 \\
\hline $\begin{array}{l}\text { Ventilat } \\
\text { ion }\end{array}$ & 137 & 6 & 2,125 & 354 & 136 & 7 & 3,256 & 465 & 137 & 6 & 3,726 & 621 \\
\hline Walls & 104 & 39 & 20,515 & 526 & 94 & 49 & 25,305 & 516 & 92 & 51 & 27,067 & 531 \\
\hline $\begin{array}{l}\text { Windo } \\
\text { ws }\end{array}$ & 134 & 9 & 24,120 & 2,680 & 130 & 13 & 26,790 & 2,061 & 130 & 13 & 31,596 & 2,430 \\
\hline
\end{tabular}

2) Retrofit strategy considering cost benefits and energy savings: Once the priorities have been setup, two strategies are followed to identify the best retrofit opportunities for 1970 s OBC detached and semi-detached houses: 
a. The first strategy adopted in this research is Brute Force Sequential Search (BFSS) method that is widely used by many researchers (Jermyn, 2014; Dembo, 2011) to select options where there are high numbers of variables involved. The purpose of this method is to identify most appropriate combination of options from a series of variables/parameters based on predefined rules. Brute Force Sequential Search method is applied to identify the most efficient retrofitting with lowest possible cost to achieve $75 \mathrm{kWh} / \mathrm{m}^{2}$. This strategy is investigated by applying the prioritised retrofitting as sequenced in table 19 and 20. Retrofitting elements such as walls and windows that involve high cost even though offer significant save of energy intensity are not considered because of their high unit cost per energy saved. Moreover from window retrofitting not much energy saving found for 1970s OBC houses. As showed in table 21 and 22 for detached and semi-detached houses, in each round one retrofit element is added from level 1 to level 3 sequentially to identify the best cost effective scenario to achieve the retrofit target. For 1970s OBC detached house, as illustrated in table 21 , Round 14 provides the most cost effective result for detached house that closely meet the retrofit target $\left(80 \mathrm{kWh} . \mathrm{m}^{2}\right)$. Round 15 and anything further does not offer significant change in energy saving in comparison with cost increase. Wall is not considered because it doubles the total retrofit cost rather adding level 2 and level 3 retrofit for low cost retrofitting provides overall energy saving with lower cost. In case of semi-detached houses, the target energy intensity can be met $\left(75 \mathrm{kWh} \cdot \mathrm{m}^{2}\right)$ at round 12 with a total cost of $\$ 16,443$ (table 22$)$. 
Table 21: Brute Force Sequential Search Method to Identify the Most Cost Effective Combination of Retrofitting for 1970s OBC Detached Houses

\begin{tabular}{|c|c|c|c|c|c|c|c|c|c|}
\hline Retrofit & Walls & Roof & $\begin{array}{l}\text { Basem } \\
\text { ent } \\
\text { walls }\end{array}$ & Slab & Windows & $\begin{array}{l}\text { Air } \\
\text { sealing }\end{array}$ & Furnace & $\begin{array}{l}\text { HRV/ER } \\
\text { V }\end{array}$ & $\begin{array}{l}\mathrm{kWh} / \\
\mathrm{m}^{2}\end{array}$ \\
\hline Round 1 & baseline & baseline & $\begin{array}{l}\text { Baselin } \\
\mathrm{e}\end{array}$ & baseline & baseline & baseline & level 1 & baseline & 143 \\
\hline Round 2 & baseline & baseline & $\begin{array}{l}\text { Baselin } \\
\mathrm{e}\end{array}$ & level 1 & baseline & baseline & level 1 & baseline & 123 \\
\hline Round 3 & baseline & level 1 & $\begin{array}{l}\text { Baselin } \\
\mathrm{e}\end{array}$ & level 1 & baseline & baseline & level 1 & baseline & 118 \\
\hline Round 4 & baseline & level 1 & level 1 & level 1 & baseline & baseline & level 1 & baseline & 107 \\
\hline Round 5 & baseline & level 1 & level 1 & level 1 & baseline & level 2 & level 1 & baseline & 100 \\
\hline Round 6 & baseline & level 1 & level 1 & level 1 & baseline & level 2 & level 2 & baseline & 96 \\
\hline Round 7 & baseline & level 1 & level 1 & level 2 & baseline & level 2 & level 2 & baseline & 94 \\
\hline Round 8 & baseline & level 2 & level 1 & level 2 & baseline & level 2 & level2 & baseline & 93 \\
\hline Round 9 & baseline & level 2 & level 1 & level 2 & baseline & level 2 & Level 3 & baseline & 90 \\
\hline Round 10 & baseline & level 2 & level 1 & level 2 & baseline & level 2 & level 3 & Level 1 & 87 \\
\hline Round 11 & baseline & level 2 & level 1 & Level 3 & baseline & level 2 & level 3 & Level 1 & 84 \\
\hline Round 12 & baseline & level 2 & level 2 & Level 3 & baseline & level 2 & level 3 & Level 1 & 82 \\
\hline Round 13 & baseline & level 2 & level 2 & Level 3 & baseline & level 2 & level 3 & Level 2 & 81 \\
\hline Round 14 & baseline & level 2 & level 3 & level 3 & baseline & level 2 & level 3 & Level 2 & 80 \\
\hline Round 15 & baseline & level 3 & level 3 & level 3 & baseline & level 2 & level 3 & Level 2 & 80 \\
\hline Round 16 & baseline & level 3 & level 3 & level 3 & baseline & level 2 & level 3 & level 3 & 80 \\
\hline
\end{tabular}

\begin{tabular}{|l|l|l|l|l|l|l|l|l|l|}
\hline Round 14 & $\begin{array}{l}\text { baselin } \\
\text { e }\end{array}$ & $\begin{array}{l}\text { level 2 } \\
\text { (Roof- } \\
\text { RSI 10.5) }\end{array}$ & $\begin{array}{l}\text { level 3 } \\
\text { (Baseme } \\
\text { nt wall- } \\
\text { RSI 3.5) }\end{array}$ & $\begin{array}{l}\text { level 3 } \\
\text { (Slab- }\end{array}$ & baseline & $\begin{array}{l}\text { level 2 } \\
\text { (ACH }\end{array}$ & $\begin{array}{l}\text { level 3 } \\
\text { 2@50Pa) }\end{array}$ & $\begin{array}{l}\text { Level 2 } \\
\begin{array}{l}\text { (Furnace } \\
\text { 97\% } \\
\text { efficient) }\end{array}\end{array}$ & $\begin{array}{l}\mathbf{8 0 k W} \\
\text { (HRV 85\% } \\
\text { efficient) }\end{array}$ \\
\hline Total cost & $\$ 0$ & $\$ 2,250$ & $\$ 3,681$ & $\$ 5,395$ & $\$ 0$ & $\$ 1,500$ & $\$ 4,333$ & $\$ 3,256$ & $\begin{array}{l}\$ 20,4 \\
15\end{array}$ \\
\hline
\end{tabular}

Table 22: Brute Force Sequential Search Method to Identify the Most Cost Effective Combination of Retrofitting for 1970s OBC Semi-Detached Houses

\begin{tabular}{|l|l|l|l|l|l|l|l|l|l|}
\hline Retrofit & Walls & Roof & $\begin{array}{l}\text { Basement } \\
\text { walls }\end{array}$ & Slab & Windows & $\begin{array}{l}\text { Air } \\
\text { sealing }\end{array}$ & Furnace & HRV/ERV & kWh/m ${ }^{2}$ \\
\hline Round 1 & baseline & baseline & Baseline & baseline & baseline & baseline & level 1 & baseline & 127 \\
\hline Round 2 & baseline & baseline & Baseline & level 1 & baseline & baseline & level 1 & baseline & 111 \\
\hline Round 3 & baseline & level 1 & Baseline & level 1 & baseline & baseline & level 1 & baseline & 108 \\
\hline Round 4 & baseline & level 1 & level 1 & level 1 & baseline & baseline & level 1 & baseline & 95 \\
\hline Round 5 & baseline & level 1 & level 1 & level 1 & baseline & level 2 & level 1 & baseline & 90 \\
\hline Round 6 & baseline & level 1 & level 1 & level 1 & baseline & level 2 & level 2 & baseline & 86 \\
\hline Round 7 & baseline & level 1 & level 1 & level 2 & baseline & level 2 & level 2 & baseline & 84 \\
\hline Round 8 & baseline & level 2 & level 1 & level 2 & baseline & level 2 & level2 & baseline & 84 \\
\hline
\end{tabular}




\begin{tabular}{|c|c|c|c|c|c|c|c|c|c|}
\hline Round 9 & baseline & level 2 & level 1 & level 2 & baseline & level 2 & Level 3 & baseline & 81 \\
\hline $\begin{array}{l}\text { Round } \\
10\end{array}$ & baseline & level 2 & level 1 & level 2 & baseline & level 2 & level 3 & Level 1 & 79 \\
\hline $\begin{array}{l}\text { Round } \\
11\end{array}$ & baseline & level 2 & level 2 & Level 2 & baseline & level 2 & level 3 & level 1 & 77 \\
\hline $\begin{array}{l}\text { Round } \\
12 \\
\end{array}$ & baseline & level 2 & level 2 & Level 3 & baseline & level 2 & level 3 & level 1 & 75 \\
\hline $\begin{array}{l}\text { Round } \\
12\end{array}$ & baseline & $\begin{array}{l}\text { level } 2 \\
\text { (Roof- } \\
\text { RSI } \\
10.5 \text { ) } \\
\end{array}$ & $\begin{array}{l}\text { level } 1 \\
\text { (Basement } \\
\text { wall-RSI 3) }\end{array}$ & $\begin{array}{l}\text { Level } 3 \\
\\
\text { (Slab- } \\
\text { RSI } \\
1.75 \text { ) } \\
\end{array}$ & baseline & $\begin{array}{l}\text { level } 2 \\
\text { (ACH } \\
2 @ 50 \mathrm{~Pa})\end{array}$ & $\begin{array}{l}\text { level } 3 \\
\text { (Furnace } \\
97 \% \\
\text { efficient) } \\
\end{array}$ & $\begin{array}{l}\text { level } 1 \\
\text { (HRV 60\% } \\
\text { efficient) }\end{array}$ & $\begin{array}{l}75 \\
\mathrm{kWh} / \mathrm{m}^{2}\end{array}$ \\
\hline $\begin{array}{l}\text { Total } \\
\text { Cost } \\
\end{array}$ & $\$ 0$ & $\$ 1,593$ & $\$ 2,958$ & $\$ 3,934$ & $\$ 0$ & $\$ 1,500$ & $\$ 4,333$ & $\$ 2,125$ & $\$ 16,443$ \\
\hline
\end{tabular}

b. The second approach is by considering all level 1 retrofit element first even though it might associate higher cost than the previous method. Wall retrofitting offers higher energy saving but also higher retrofitting cost. As table 23 and 24 shows, it is found that retrofit target can be achieved for 1970s OBC detached and semi-detached houses with level 1 retrofitting if cost is compromised. Table 23 shows that for detached house round 5 of level 1 retrofitting meet the energy intensity target with a total cost of $\$ 40,953$. Here level 1 retrofit includes furnace, slab, roof, basement wall and exterior wall upgrade to reach target energy intensity. Table 24 shows for semidetached house similar retrofitting by round 4 with a total cost of $\$ 28,680$. Semidetached house level 1 retrofit includes furnace, slab, roof and exterior wall upgradation to achieve target energy intensity. For semi-detached house $75 \mathrm{kWh} / \mathrm{m}^{2}$ energy intensity received before adding basement wall insulation. This is because of overall energy use of semi-detached house is low comparing to detached house and shared wall helps to minimise the heat loss. So target energy intensity can be achieved without retrofitting basement wall while three sides of outdoor walls are retrofitted with high performance insulation. 
Table 23: Minimum Retrofit Level to Meet the Retrofit Target for 1970s OBC Detached Houses

\begin{tabular}{|c|c|c|c|c|c|c|c|c|c|}
\hline Retrofit & Walls & Roof & $\begin{array}{l}\text { Basement } \\
\text { walls }\end{array}$ & Slab & Windows & $\begin{array}{l}\text { Air } \\
\text { sealing }\end{array}$ & $\begin{array}{l}\text { Furnac } \\
\text { e }\end{array}$ & $\begin{array}{l}\text { HRV/ER } \\
\text { V }\end{array}$ & $\mathrm{kWh} / \mathrm{m}^{2}$ \\
\hline $\begin{array}{l}\text { Round } \\
1\end{array}$ & baseline & baseline & baseline & baseline & baseline & baseline & level 1 & baseline & 143 \\
\hline $\begin{array}{l}\text { Round } \\
2\end{array}$ & baseline & baseline & baseline & level 1 & baseline & baseline & level 1 & baseline & 123 \\
\hline $\begin{array}{l}\text { Round } \\
3\end{array}$ & baseline & level 1 & baseline & level 1 & baseline & baseline & level 1 & baseline & 118 \\
\hline $\begin{array}{l}\text { Round } \\
4\end{array}$ & baseline & level 1 & level 1 & level 1 & baseline & baseline & level 1 & baseline & 107 \\
\hline $\begin{array}{l}\text { Round } \\
5\end{array}$ & Level 1 & level 1 & level 1 & level 1 & baseline & baseline & level 1 & baseline & 75 \\
\hline $\begin{array}{l}\text { Round } \\
5\end{array}$ & $\begin{array}{l}\text { Level } 1 \\
\text { (Wall- } \\
\text { RSI 4) }\end{array}$ & $\begin{array}{l}\text { level } 1 \\
\text { (Roof- } \\
\text { RSI 9) }\end{array}$ & $\begin{array}{l}\text { level } 1 \\
\text { (Basement } \\
\text { wall-RSI 2) }\end{array}$ & $\begin{array}{l}\text { level } 1 \\
\text { (Slab- } \\
\text { RSI 0.75) }\end{array}$ & baseline & $\begin{array}{l}\text { baselin } \\
\text { e }\end{array}$ & $\begin{array}{l}\text { level } 1 \\
\text { (Furnace } \\
90 \% \\
\text { efficient) }\end{array}$ & $\begin{array}{l}\text { baselin } \\
\text { e }\end{array}$ & $\begin{array}{l}\text { 75kWh/ } \\
\mathrm{m}^{2}\end{array}$ \\
\hline $\begin{array}{l}\text { Total } \\
\text { cost }\end{array}$ & $\$ 27,418$ & $\$ 1,974$ & $\$ 3,461$ & $\$ 4,950$ & $\$ 0$ & $\$ 0$ & $\$ 3,150$ & $\$ 0$ & $\$ 40,953$ \\
\hline
\end{tabular}

Table 24: Minimum Retrofit Level to Meet the Retrofit Target for 1970s OBC Semi-Detached Houses

\begin{tabular}{|c|c|c|c|c|c|c|c|c|c|}
\hline Retrofit & Walls & Roof & $\begin{array}{l}\text { Basement } \\
\text { walls }\end{array}$ & Slab & Windows & $\begin{array}{l}\text { Air } \\
\text { sealing }\end{array}$ & Furnace & HRV/ERV & $\mathrm{kWh} / \mathrm{m}^{2}$ \\
\hline $\begin{array}{l}\text { Round } \\
1\end{array}$ & baseline & baseline & baseline & baseline & baseline & baseline & level 1 & baseline & 127 \\
\hline $\begin{array}{l}\text { Round } \\
2\end{array}$ & baseline & baseline & baseline & level 1 & baseline & baseline & level 1 & baseline & 111 \\
\hline $\begin{array}{l}\text { Round } \\
3 \\
\end{array}$ & baseline & level 1 & baseline & level 1 & baseline & baseline & level 1 & baseline & 108 \\
\hline $\begin{array}{l}\text { Round } \\
4\end{array}$ & Level 1 & level 1 & baseline & level 1 & baseline & baseline & level 1 & baseline & 75 \\
\hline $\begin{array}{l}\text { Round } \\
4\end{array}$ & $\begin{array}{l}\text { Level } 1 \\
\text { (Wall-RSI } \\
\text { 4) }\end{array}$ & $\begin{array}{l}\text { level } 1 \\
\text { (Roof- } \\
\text { RSI 9) }\end{array}$ & baseline & $\begin{array}{l}\text { level } 1 \\
\text { (Slab- } \\
\text { RSI 0.75) }\end{array}$ & baseline & baseline & $\begin{array}{l}\text { level } 1 \\
\text { (Furnace } \\
90 \% \\
\text { efficient) }\end{array}$ & baseline & $\begin{array}{l}75 \\
\mathrm{kWh} / \mathrm{m}^{2}\end{array}$ \\
\hline $\begin{array}{l}\text { Total } \\
\text { cost }\end{array}$ & $\$ 20,515$ & $\$ 1,397$ & $\$ 0$ & $\$ 3,618$ & $\$ 0$ & $\$ 0$ & $\$ 3,150$ & $\$ 0$ & $\$ 28,680$ \\
\hline
\end{tabular}

In conclusion, it can be summarized that above retrofitting strategies provide flexibility of selection of retrofitting options considering cost/benefit and efficient energy performance of house. The significant finding of this research is the exterior wall of 1970 s OBC archetype as it is one of the most costly and energy savings component in the building envelope system. If wall is retrofitted at level 1 it saves almost $25 \%$ (detached) \& 27\% (semi-detached) of energy 
intensity for heating and cooling load and helps to reach the target without moving to any level 2 retrofit options. But high expenses of wall retrofitting will be involved with this approach which can be challenging for consumers.

\section{Conclusions}

This research investigated 1970s detached and semi-detached houses of old Toronto neighbourhoods to understand the impact of micro level energy consumption on communities and retrofit opportunities to improve energy efficiency. This has been done through an understanding of the archetypes, composition of local housing and their physical characteristics that influence energy consumption. A detail investigation of archetypes helped to produce a baseline model that can be further utilized for investigating retrofit opportunities. Although primarily Jermyn's (2014) methodology has been adopted, there were few differences have been made for a better understanding and performance of the investigation:

1. Unlike Jermyn's neighbourhood selection process utilizing existing literature, this research performed a comprehensive GIS Mapping to identify areas that are predominantly represented by 1970 s OBC archetype which results determining a consisting characteristic of the archetype.

2. Jermyn's baseline model includes window wall ratios of surveyed houses that are averaged based on their orientation (north, south, east and west) and not by the front, side and rear wall definition. As a result, an average north wall data includes both front and side wall which does not represent either front wall or side wall. To resolve this and improve the accuracy of results, this research utilizes the average window-wall ratio calculated based on actual front, side and rear wall data regardless their orientation.

3. Unlike Jermyn's linear cost-benefit approach for the retrofitting analysis, this research adapted two different approaches to understand the performance difference between highest 
level of retrofit and optimum combination of retrofit for highest cost-benefit. The first approach involved retrofitting of all components to maximize energy efficiency without considering costbenefit and the second approach involved a permutation and combination of various retrofitting components to identify the best possible combination that confirm the target energy intensity with lowest investment on retrofitting.

The findings of this research are illustrated in following three sequential phases:

\subsection{0s OBC Archetype}

While investigating neighbourhoods and 1970s archetype house within urban Old Toronto it was found that this particular houses are not contributing highly in overall neighbourhood energy intensity as these houses are comparatively airtight and durable. Moreover, there are fewer 1970s single detached and semi-detached houses in comparison to other archetypes within

"Old Toronto". The highly energy intense neighbourhoods consists of a large number of Century and War-Time houses as determined by Jermyn (2014), which directly impacts on high energy intensity of old Toronto's neighbourhoods. However, the comparatively high density of 70s OBC single detached and semi-detached houses found within peripheral areas of "Old Toronto" mostly at north (Forest Hill North \& Lawrence Park South) and west areas (High Park-Swansea, High Park North and Junction Area). Furthermore, the community council area of Toronto district which includes Etobicoke York district, North York district and Scarborough district has more high density 1970s houses which could create large impact on overall local neighbourhood's energy intensity. Therefore, the retrofitting strategy of this archetype in term of high energy intensity neighbourhood is more applicable for outer fringe area of city of Toronto (Etobicoke York district, North York district and Scarborough district). 


\subsection{Baseline Model and Energy performance of 1970s Archetype}

The building archetype is a theoretical concept to describe similar building and provide basic information for their identical features (Jermyn D., 2014). However, even within the same archetype, houses may vary in size, partial retrofits that may or may have not been done, occupant's number and behaviour, etc. may not fully reflect the archetype model's features. This research involves developing an energy model to approximate the energy performance of 1970s OBC archetypes house. The baseline energy model results found differences comparing to Blaszak and Richman (2013) and the Natural Resources Canada Urban Archetypes Project (NRCan - CanmetENERGY, 2009) and identifies $23-27 \%$ difference in overall energy intensity. This is ensuring that different methodology and data sets collected from archetypes and use of different software can effects on end result. The result found from Blaszak and Richman (2013) by using HOT2000 software shows differences from result found by EnergyPlus software with EnergyPlus results being lower energy consumption compare to HOT2000 software. While EnergyPlus baseline result was using for calibration with real-time energy bills, it is found that actual energy consumption is lower than the calculated baseline result. This can be attributed to potential renovation or retrofit of selected houses that have not been properly documented and difficult to estimate. Moreover, occupants' behaviour and habits, as well as times of absence also directly affect the energy usage. In this research, the overall energy intensity for 1970 s OBC detached and semi-detached houses are found to be $193 \mathrm{kWh} / \mathrm{m}^{2} \& 161 \mathrm{kWh} / \mathrm{m}^{2}$, respectively. For heating and cooling load the energy intensity found $176 \mathrm{kWh} / \mathrm{m}^{2} \& 143 \mathrm{kWh} / \mathrm{m}^{2}$ by using EnergyPlus software.

\subsection{Energy Efficient Retrofit Impact \& Target Energy Intensity $75 \mathrm{kWh} / \mathrm{m}^{2}$ :}

The baseline model of 1970 s archetype houses is retrofitted at three levels considering high energy efficiency strategies. In all three levels of retrofitting, it is found that building envelope system and furnace have the highest impact on energy intensity. Among building envelope 
system, wall and slab retrofits support the greatest reduction of energy use for both detached and semi-detached houses. Although window glazing ratio is high, EnergyPlus result did not show reasonable energy savings from all three levels of window retrofits. When three levels of retrofitting are examined separately, results show an achievement of less than $75 \mathrm{kWh} / \mathrm{m}^{2}$ energy intensity for heating cooling load which is lower than the target. Among these three levels the most economically balanced retrofitting option is verified through feasibility study.

At minimum retrofitting intervention, the target energy intensity $75 \mathrm{kWh} / \mathrm{m}^{2}$ for heating cooling load has been achieved for detached house by incorporating level 1- furnace, slab, roof, basement wall and exterior wall retrofitting option in baseline energy model (Table 23). For semi-detached houses target energy intensity achieved by adapting level 1 - furnace, slab, roof and exterior wall retrofit selections (Table 24) in EnergyPlus model. Semi-detached house is smaller in volume and floor area, and consumes less energy compared to detached house. Moreover, there is a shared wall, which reduces heat loss to outdoor. Therefore, it is logical that for semi-detached house target can be fulfilled without basement wall retrofitting whereas detached house needs basement wall retrofit to reach target energy intensity. On the other hand, if this retrofitting option is verified from cost/benefit perspective, these options would not be very attractive for house owners due to considerably higher costs. For detached house- level 1 upgrade, all four components of retrofit cost is $\$ 40,953$ and for semi-detached house the cost is $\$ 28,680$. As a second approach, the most energy efficient retrofit option with lowest possible cost is investigated by Brute Force Sequential Search (BFSS) method with a target energy intensity of heating cooling load $75 \mathrm{kWh} / \mathrm{m}^{2}$. Table 21 illustrates that using Brute Force Sequential Search method a detached house can achieve the minimum energy intensity of $80 \mathrm{kWh} / \mathrm{m}^{2}$ with a cost of $\$ 20,415$ without wall and window (most expensive) retrofitting. However, to achieve $75 \mathrm{kWh} / \mathrm{m}^{2}$ energy intensity wall/window retrofit is still required. For semidetached house, the energy intensity target of $75 \mathrm{kWh} / \mathrm{m}^{2}$ can be achieved (table 22) with a cost 
of $\$ 16,340$ without retrofitting window or wall. It can be summarized that for 1970 s OBC single detached house target $75 \mathrm{kWh} / \mathrm{m}^{2}$ energy intensity cannot be achieved without exterior wall retrofitting. Although these houses have very efficient shape from geometric perspective (rectangle), there are large proportion of exterior walls which causes heat losses to outdoor. Therefore, for detached house exterior wall retrofit is essential for high energy performance. For semi-detached house $75 \mathrm{kWh} / \mathrm{m} 2$ target achieved without retrofitting costly wall and windows. This is possible because the heat loss of semi-detached houses is much lower in comparison to the detached houses because of two principal reasons:

i. Existence of a shared wall between two units which is not considered for heat loss.

ii. Because of only three exterior wall (the side wall merely has openings) with comparatively less window wall ratio (exterior opening).

For the above two reasons, the total heat loss can be minimized significantly by other low cost retrofit opportunities (e.g. HVAC, HRV/ERV, Slab, Roof and Basement wall) without wall and window retrofitting.

\section{Contributions and Further Research}

This research has established a clear outcome of energy performance and high performance retrofitting options for 1970s OBC archetype houses in urban Toronto. The focus is given only within old city of Toronto area for 1970s single detached and semi-detached archetype houses for survey and data collection. The research identified neighbourhoods that are dominantly represented by 1970s OBC archetype through a comprehensive GIS analysis. The collected data from an extensive research survey also established a consistent characteristic of 1970s OBC archetype among all studied neighbourhoods and made corrections of Blaszak's model. It is investigated that the average neighbourhood energy intensity of these particular houses would have more impact in peripheral municipal area (Etobicoke York district, North York district and Scarborough district). The density of new houses is more intense in those districts, and it 
was found that the 1970s houses of those areas are large in volume and floor area (consuming more energy). Future research can be suggested to investigate this archetype in other municipal districts to verify the average energy impact on those neighbourhoods. In neighbourhood scale energy use investigation of 1970 s house is more appropriate in those districts. While this research is only focused on 1970s OBC archetype houses, the same energy performance analysis can be expanded by considering Modern archetypes which was developed by Blaszak and Richman (2013).

In 1970s OBC house investigation, it is established that, wall retrofitting is the most effective but cost sensitive component. Exteriors walls are contributing most in heat loss among all of the elements of building envelope. There is need of more research work on wall retrofitting in order to assess the overall durability, energy performance and cost reduction. It is also desirable to verify the current wall structure durability analysis and scope of appropriate economically efficient retrofit. In this case, different cost effective materials and construction techniques can be tested for more balanced upgrade. Moreover the interior wall retrofitting option can be verified because minimizing the interior space may not be beneficial and appreciated by consumers.

In this research for 1970s OBC houses, windows are not found highly effective for retrofitting although window wall ratio is found large enough comparing to other archetypes. Blaszak and Richman (2013) with HOT2000 software found that both wall and window contribute highly to heat loss and need to be retrofitted. On the other hand, Jermyn (2014) found windows as less priority factor for Century and War Time archetypes with EnergyPlus software. Future research could explore the windows of 1970 s OBC houses with other simulation software to crosscheck how windows are performing and identify the detail data input which are effecting on window performance. Moreover, the statistical Normalized Mean Bias Error (NMBE) and the Coefficient 
of Variation of the Root Mean Squared Error (CVRSME) values can be calculated for both baseline energy models in the calibration process to enhance the validation of baseline result.

In cost benefit analysis the unit cost price for retrofitting of various elements of house is taken from Jermyn's (2014) research work as both of the archetypes (detached and semi-detached) have same wood construction structure. This unit pricing and cost analysis can be further developed for more realistic costing by consulting with greater number of contractors to achieve more accurate cost analysis. 
Appendix A: Number of Total Single Detached \& Semi-Detached Houses in Urban Toronto Neighbourhoods and Number of $70 \mathrm{~s}$ OBC Archetypes within these neighbourhoods

\begin{tabular}{|c|c|c|c|c|c|c|}
\hline & Neighbourhood List & $\begin{array}{l}\text { Number } \\
\text { of Single } \\
\text { Detached } \\
\text { Houses }\end{array}$ & $\begin{array}{l}\text { Number } \\
\text { of Semi } \\
\text { Detached } \\
\text { Houses }\end{array}$ & $\begin{array}{l}\text { Number of } \\
70 \text { s OBC } \\
\text { Single } \\
\text { detached } \\
\text { Archetype } \\
\text { Houses }\end{array}$ & $\begin{array}{l}\text { Number of } 70 \text { s } \\
\text { OBC Semi } \\
\text { Detached } \\
\text { Archetype } \\
\text { Houses }\end{array}$ & $\begin{array}{l}\text { Energy } \\
\text { Intensity for } \\
1970 \mathrm{~s} \\
\text { single } \\
\text { detached } \\
\text { houses } \\
\mathrm{kWh} / \mathrm{m}^{2}\end{array}$ \\
\hline 62 & East End-Danforth & 1735 & 1880 & 184 & 200 & 349 \\
\hline 63 & The Beaches & 2580 & 1455 & 109 & 61 & 366 \\
\hline 64 & Woodbine Corridor & 850 & 1500 & 33 & 58 & 367 \\
\hline 65 & Greenwood-Coxwell & 925 & 1415 & 80 & 122 & 356 \\
\hline 66 & Danforth Village & 665 & 1220 & 48 & 87 & 372 \\
\hline 67 & Playter Estates-Danforth & 660 & 600 & 56 & 51 & 368 \\
\hline 68 & North Riverdale & 785 & 1205 & 30 & 46 & 383 \\
\hline 69 & Blake-Jones & 445 & 615 & 42 & 56 & 365 \\
\hline 70 & South Riverdale & 835 & 2205 & 52 & 137 & 373 \\
\hline 71 & $\begin{array}{l}\text { Cabbagetown-South St. } \\
\text { James Town }\end{array}$ & 150 & 425 & 28 & 78 & 336 \\
\hline 72 & Regent Park & 5 & 45 & 1 & 6 & 296 \\
\hline 73 & Moss Park & 75 & 95 & 5 & 6 & 303 \\
\hline 74 & North St. James Town & 5 & 0 & 1 & 0 & 307 \\
\hline 75 & Church-Yonge Corridor & 15 & 25 & 3 & 4 & 284 \\
\hline 76 & Bay Street Corridor & 0 & 5 & 0 & 1 & 0 \\
\hline 77 & $\begin{array}{l}\text { Waterfront Communities- } \\
\text { The Island }\end{array}$ & 255 & 30 & 30 & 3 & 247 \\
\hline 78 & Kensington-Chinatown & 85 & 185 & 17 & 36 & 321 \\
\hline 79 & University & 115 & 210 & 12 & 21 & 368 \\
\hline 80 & Palmerston-Little Italy & 315 & 855 & 11 & 29 & 378 \\
\hline 81 & Trinity-Bellwoods & 320 & 720 & 13 & 28 & 374 \\
\hline 82 & Niagara & 5 & 0 & 1 & 0 & 231 \\
\hline 83 & Durrerin Grove & 300 & 510 & 29 & 49 & 352 \\
\hline 84 & Little Portugal & 260 & 480 & 16 & 30 & 369 \\
\hline 85 & South Parkdale & 185 & 150 & 23 & 19 & 327 \\
\hline 86 & Roncesvalles & 630 & 995 & 36 & 60 & 374 \\
\hline 87 & High Park-Swansea & 2620 & 495 & 745 & 60 & 260 \\
\hline 88 & High Park North & 1375 & 580 & 301 & 57 & 268 \\
\hline 89 & $\begin{array}{l}\text { Runnymede-Bloor West } \\
\text { Village }\end{array}$ & 1980 & 765 & 200 & 60 & 270 \\
\hline 90 & Junction Area & 750 & 965 & 379 & 488 & 264 \\
\hline 91 & Weston-Pellam Park & 535 & 1305 & 50 & 122 & 333 \\
\hline 92 & Corso Italia-Davenport & 1280 & 1225 & 99 & 95 & 356 \\
\hline 93 & $\begin{array}{l}\text { Dovercourt-Wallace } \\
\text { Emerson-Junction }\end{array}$ & 1590 & 2145 & 112 & 151 & 351 \\
\hline 94 & Wychwood & 945 & 920 & 97 & 94 & 355 \\
\hline 95 & Annex & 630 & 1120 & 57 & 101 & 343 \\
\hline
\end{tabular}




\begin{tabular}{|l|l|l|l|l|l|l|}
\hline 96 & Casa Loma & 875 & 230 & 75 & 20 & 341 \\
\hline 97 & Yonge-St. Clair & 540 & 390 & 60 & 43 & 318 \\
\hline 98 & Rosedale-Moore Park & 2450 & 445 & 257 & 47 & 332 \\
\hline 99 & Mount Pleasant East & 2155 & 1570 & 224 & 163 & 352 \\
\hline 100 & Yonge-Eglinton & 1410 & 460 & 210 & 69 & 349 \\
\hline 101 & Forest Hill South & 1740 & 50 & 148 & 4 & 348 \\
\hline 102 & Forest Hill North & 1450 & 10 & 139 & 1 & 298 \\
\hline 103 & Lawrence Park South & 3415 & 110 & 77 & 3 & 365 \\
\hline 104 & Mount Pleasant West & 475 & 200 & 93 & 39 & 284 \\
\hline 105 & Lawrence Park North & 3110 & 865 & 54 & 15 & 373 \\
\hline
\end{tabular}




\section{Appendix B: Ryerson University Ethics Approval}

\section{RYERSONUNIVERSITY \\ RESEARCH ETHICS BOARD}

To: Sharmeen Niger

Department of Architectural Science

Re: REB 2015-084: Energy consumption of Toronto's post-70 single-family residential detached houses and high performance energy retrofit opportunities.

Date: April 1, 2015

\section{Dear Sharmeen Niger,}

The review of your protocol REB File REB 2015-084 is now complete. The project has been approved for a one year period. Please note that before proceeding with your project, compliance with other required University approvals/certifications, institutional requirements, or governmental authorizations may be required.

This approval may be extended after one year upon request. Please be advised that if the project is not renewed, approval will expire and no more research involving humans may take place. If this is a funded project, access to research funds may also be affected.

Please note that REB approval policies require that you adhere strictly to the protocol as last reviewed by the REB and that any modifications must be approved by the Board before they can be implemented. Adverse or unexpected events must be reported to the REB as soon as possible with an indication from the Principal Investigator as to how, in the view of the Principal Investigator, these events affect the continuation of the protocol.

Finally, if research subjects are in the care of a health facility, at a school, or other institution or community organization, it is the responsibility of the Principal Investigator to ensure that the ethical guidelines and approvals of those facilities or institutions are obtained and filed with the REB prior to the initiation of any research.

Please quote your REB file number (REB 2015-084) on future correspondence.

Congratulations and best of luck in conducting your research.

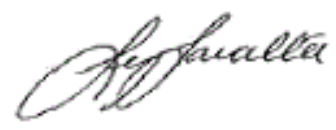

Lynn Lavallée, $\mathrm{Ph} . \mathrm{D}$.

Chair, Research Ethics Board 


\section{RYERSON UNIVERSITY}

\section{SURVEY QUESTIONNAIRE}

Energy Consumption of Toronto's Post-70 Single-Family Residential Detached Houses and High Performance Energy Retrofit Opportunities

\section{PART 1}

1) Have you made any renovations to your home? (Please circle) YES NO If yes, please list the renovations made:

2) Are you aware of any renovations made by previous owners? YES If yes, please list the renovations made:

NO

$$
\text { If yes, please list the renovations made: }
$$

3) What types of major appliances are used in your home? (Please check all that apply)
$\square$ Kitchen Fan
$\square$ Kitchen Stove
$\square$ Refrigerator
$\square$ Dishwasher
$\square$ Clothes Washer
$\square$ Clothes Dryer
Other

(list)

4) When are the appliances typically used? (Circle all that apply)
Kitchen Fan
Days Nights
Weekend Days
Weekend Nights
Rarely

Kitchen Stove......... Days Nights Weekend Days Weekend Nights Rarely

Dishwasher........... Days Nights Weekend Days Weekend Nights Rarely

Clothes Washer.......Days Nights Weekend Days Weekend Nights Rarely 
Clothes Dryer........ Days Nights Weekend Days Weekend Nights Rarely

Other_ Days Nights Weekend Days Weekend Nights Rarely

Other_ Days Nights Weekend Days Weekend Nights Rarely

Other_Days Nights Weekend Days Weekend Nights Rarely

5) For how many hours per day are the appliances typically used? (List number of hours) Kitchen Fan Clothes Washer Other Kitchen Stove Clothes Dryer Dishwasher Other

6) How is your home heated? (Air Forced / electric board)

7) In what room is the thermostat located?

8) What is the occupancy number?

\section{PART 2: Observations \& interview}

\begin{tabular}{|l|l|l|}
\hline 1 & $\begin{array}{l}\text { What is the building area/building } \\
\text { footprint (in square feet or square } \\
\text { meter)? }\end{array}$ & \\
\hline 2 & What is the Heated Floor Area? & \\
\hline
\end{tabular}




\begin{tabular}{|c|c|c|}
\hline 3 & $\begin{array}{l}\text { What is the number of storey of the } \\
\text { building? }\end{array}$ & \\
\hline 4 & $\begin{array}{l}\text { What is the shape of the building? } \\
\text { (e.g. } \\
\text { rectangular/square/composite) }\end{array}$ & \\
\hline 5 & What is the year of construction? & \\
\hline 6 & $\begin{array}{l}\text { What is the orientation of the lot? } \\
\text { (e.g. north facing) }\end{array}$ & \\
\hline 7 & $\begin{array}{l}\text { Are there any other special } \\
\text { features (attic, porch, garage etc.) }\end{array}$ & \\
\hline 8 & $\begin{array}{l}\text { What is the type of roof? } \\
\text { (e.g. Gable/Hip/Flat) }\end{array}$ & \\
\hline 9 & $\begin{array}{l}\text { What is the structural system? } \\
\text { (e.g Wood/R.C.C) }\end{array}$ & \\
\hline 10 & $\begin{array}{l}\text { What type of cladding placed at } \\
\text { exterior surface? } \\
\text { (e.g. Brick, Stone, Stucco, } \\
\text { Concrete, composite) }\end{array}$ & \\
\hline 11 & $\begin{array}{l}\text { What are the assemblies of wall, } \\
\text { ceiling \& foundation of the } \\
\text { building? (please provide if you } \\
\text { have any drawings) }\end{array}$ & \\
\hline \multirow[t]{5}{*}{12} & $\begin{array}{l}\text { What are the glazing ratio } \\
\text { (percentage) of the building }\end{array}$ & \\
\hline & Front & \\
\hline & Side & \\
\hline & Side & \\
\hline & Rear & \\
\hline 13 & $\begin{array}{l}\text { What type of windows placed in } \\
\text { house? } \\
\text { (double glazing/triple glazing) }\end{array}$ & \\
\hline 14 & $\begin{array}{l}\text { What is the door type } \\
\text { (insulated/un-insulated) }\end{array}$ & \\
\hline \multirow[t]{4}{*}{15} & HVAC system (Type) & \\
\hline & What is the cooling system? & \\
\hline & What is the main control location? & \\
\hline & What is the vent flow rate? (to be & \\
\hline
\end{tabular}




\begin{tabular}{|l|l|l|}
\hline & filled up by the researcher) & \\
\hline 16 & Internal gain & \\
\cline { 2 - 3 } & $\begin{array}{l}\text { What is the total number of lighting } \\
\text { units (bulbs)? }\end{array}$ & \\
$\begin{array}{l}\text { Number Normal Bulbs/ Energy } \\
\text { efficient/LED }\end{array}$ & \\
\hline
\end{tabular}

\section{PART 3: Energy Usage:}

Please see your monthly electricity and gas bill and provide monthly usage (e.g. electricity in KWh and gas in cubic meter) from the bill for last 12 months (Jan 2014-Dec 2014):

\begin{tabular}{|l|l|l|}
\hline Month & Electricity (KWh) & Gas (cubic meter) \\
\hline January & & \\
\hline February & & \\
\hline March & & \\
\hline April & & \\
\hline May & & \\
\hline June & & \\
\hline July & & \\
\hline August & & \\
\hline September & & \\
\hline October & & \\
\hline November & & \\
\hline December & & \\
\hline
\end{tabular}

Note: Participant can provide 1 year Energy Bill (electricity \& gas) to researcher (omitting personal details) to get accurate result. 
Appendix D: Survey Data for 70s OBC Archetype Houses

\section{Survey Data for 1970s OBC Single Detached Houses}

Housing Inspection Data: 1970s OBC Single Detached Houses

\begin{tabular}{|c|c|c|c|c|c|c|c|c|c|c|c|c|c|}
\hline & \multirow[b]{2}{*}{$\begin{array}{l}\text { House } \\
\text { Type }\end{array}$} & \multirow[b]{2}{*}{ Neighbourhood } & \multirow[b]{2}{*}{ Shape } & \multicolumn{2}{|c|}{ Footprint } & \multirow[b]{2}{*}{$\begin{array}{l}\text { Area } \\
\left(\mathrm{m}^{2}\right)\end{array}$} & \multirow[b]{2}{*}{ Structure } & \multirow[b]{2}{*}{ Cladding } & \multirow[b]{2}{*}{ Roof } & \multicolumn{4}{|l|}{ Height(m) } \\
\hline & & & & $\begin{array}{l}\text { Width } \\
(\mathrm{m})\end{array}$ & $\begin{array}{l}\text { length } \\
\text { (m) }\end{array}$ & & & & & Basement & $\begin{array}{l}\text { Above } \\
\text { Grade }\end{array}$ & Storey 1 & $\begin{array}{l}\text { Storey } \\
2\end{array}$ \\
\hline 1 & 1970s OBC & High Park Swansea & Rectangle & 8.5 & 15 & 278.7 & Wood & Brick & Shingle & 2.43 & 1.2 & 2.8 & 2.7 \\
\hline 2 & 1970s OBC & Lawrence Park South & Rectangle & 6.68 & 18.9 & 241.54 & Wood & Brick & Shingle & 2.5 & 1.5 & 2.6 & 2.6 \\
\hline 3 & 1970s OBC & High Park Swansea & Rectangle & 8.2 & 14.8 & 265.2 & Wood & Brick & Shingle & 2.4 & 0.3 & 2.6 & 2.5 \\
\hline 4 & 1970s OBC & Forest Hill North & Rectangle & 6.75 & 12.98 & 257.4 & Wood & Brick & Shingle & 2.4 & 1.2 & 2.8 & 2.7 \\
\hline \multicolumn{3}{|c|}{ Average or Typical Characteristics } & Rectangle & 7.5 & 15.4 & 260.7 & Wood & Brick & Shingle & 2.4 & 1.1 & 2.7 & 2.6 \\
\hline
\end{tabular}

\begin{tabular}{|l|l|l|}
\hline HVAC System & Thermostat Location & Occupancy number \\
\hline Forced Air Gas & Main Hallway & 2 \\
\hline Forced Air Gas / AC Electric & Dining Room & 2 \\
\hline Forced Air Gas & Dining Room & 5 \\
\hline Forced Air Gas & Living Room & 4 \\
\hline Forced Air Gas & Dining Room & 3.3 \\
\hline
\end{tabular}

\begin{tabular}{|l|l|l|l|l|l|}
\hline & \multicolumn{4}{|l|}{ Window to Wall Ratio } & Glazing \\
\hline & Front & Back & side 1 & side 2 & \\
\hline 1 & $25 \%$ & $20 \%$ & $8 \%$ & $5 \%$ & Double glaze \\
\hline 2 & $30 \%$ & $18 \%$ & $15 \%$ & $0 \%$ & Double glaze \\
\hline 3 & $20 \%$ & $20 \%$ & $5 \%$ & $0 \%$ & Double glaze \\
\hline 4 & $35 \%$ & $25 \%$ & $5 \%$ & $5 \%$ & Double glaze \\
\hline & $\mathbf{2 8 \%}$ & $\mathbf{2 1} \%$ & $\mathbf{8} \%$ & $\mathbf{3} \%$ & Double glaze \\
\hline
\end{tabular}




\begin{tabular}{|c|c|c|c|c|c|c|c|c|c|c|c|c|}
\hline & \multicolumn{10}{|c|}{ Window Frame Data (cm) } & \multicolumn{2}{|l|}{ Door } \\
\hline & $\begin{array}{l}\text { Frame } \\
\text { Width }\end{array}$ & $\begin{array}{l}\text { Divider } \\
\text { Type }\end{array}$ & $\begin{array}{l}\text { Divider } \\
\text { width }\end{array}$ & $\begin{array}{l}\text { \# } \\
\text { Horizontal }\end{array}$ & \# Vertical & $\begin{array}{l}\text { Divider } \\
\text { Projection }\end{array}$ & Sill Depth & $\begin{array}{l}\text { Sill } \\
\text { Material }\end{array}$ & $\begin{array}{l}\text { Reveal } \\
\text { Depth }\end{array}$ & $\begin{array}{l}\text { Reveal } \\
\text { Material }\end{array}$ & $\begin{array}{l}\text { Front } \\
\text { Door }\left(\mathrm{m}^{2}\right)\end{array}$ & Insulation \\
\hline 1 & 7.62 & Lite & 2.5 & 2 & $\mathrm{n} / \mathrm{a}$ & 2.5 & 25.4 & Wood & 25.4 & Wood & 1.9 & Insulated \\
\hline 2 & 8.89 & Lite & 7.6 & 1 & $\mathrm{n} / \mathrm{a}$ & 3.8 & 20.3 & Wood & 20.3 & Wood & 1.84 & Insulated \\
\hline 3 & 10.16 & Lite & 6.4 & 1 & $\mathrm{n} / \mathrm{a}$ & 2.5 & 15.2 & Wood & 15.2 & Wood & 1.9 & Insulated \\
\hline \multirow[t]{2}{*}{4} & 10.24 & Lite & 6.4 & 2 & $\mathrm{n} / \mathrm{a}$ & 1.3 & 15.8 & Wood & 15.8 & Wood & 1.89 & Insulated \\
\hline & 9.23 & Lite & 5.7 & 1.5 & $\mathrm{n} / \mathrm{a}$ & 2.5 & 19.2 & Wood & 19.2 & Wood & 1.9 & Insulated \\
\hline
\end{tabular}

\begin{tabular}{|c|c|c|c|c|c|c|c|c|c|c|c|c|c|c|c|c|c|}
\hline & \multirow{2}{*}{ House Type } & \multirow{2}{*}{ Neighbourhood } & \multirow{2}{*}{$\begin{array}{l}\text { Renovation } \\
\text { done by } \\
\text { current } \\
\text { owner }\end{array}$} & \multirow{2}{*}{$\begin{array}{l}\text { Renovation } \\
\text { done } \\
\text { Previously }\end{array}$} & \multicolumn{7}{|c|}{ Use of Appliances (hours/per day) } & \multicolumn{6}{|c|}{ Appliances (time of use- D, N, WD, WN, R) } \\
\hline & & & & & $\begin{array}{l}\text { Kitchen } \\
\text { Fan }\end{array}$ & Stove & Fridge & $\begin{array}{l}\text { Dish } \\
\text { washer }\end{array}$ & $\begin{array}{l}\text { cloth } \\
\text { washer }\end{array}$ & $\begin{array}{l}\text { cloth } \\
\text { dryer }\end{array}$ & Others & $\begin{array}{l}\text { Kitchen } \\
\text { Fan }\end{array}$ & Stove & $\begin{array}{l}\text { Dish } \\
\text { washer }\end{array}$ & $\begin{array}{l}\text { cloth } \\
\text { washer }\end{array}$ & $\begin{array}{l}\text { cloth } \\
\text { dryer }\end{array}$ & Others \\
\hline 1 & $\begin{array}{l}70 \text { 's OBC } \\
\text { Single } \\
\text { detached }\end{array}$ & $\begin{array}{l}\text { High Park } \\
\text { Swansea }\end{array}$ & No & Yes & $n / a$ & 1 & Always & 1.5 & 0.5 & 0.5 & $n / a$ & $R$ & $D, N, W D, W N$ & $\mathrm{~N}, \mathrm{WN}$ & $\mathrm{N}, \mathrm{WD}, \mathrm{WN}$ & $\mathrm{N}, \mathrm{WD}, \mathrm{WN}$ & $n / a$ \\
\hline 2 & $\begin{array}{l}70 \text { 's OBC } \\
\text { Single } \\
\text { detached }\end{array}$ & $\begin{array}{l}\text { Lawrence Park } \\
\text { South }\end{array}$ & Yes & No & 0.5 & 1 & Always & 1 & 0.5 & 0.5 & $n / a$ & $\mathrm{~N}, \mathrm{WN}$ & $D, N, W D, W N$ & $\mathrm{~N}, \mathrm{WN}$ & $\mathrm{N}, \mathrm{WD}$ & $\mathrm{N}, \mathrm{WD}$ & $n / a$ \\
\hline 3 & $\begin{array}{l}70 \text { 's OBC } \\
\text { Single } \\
\text { detached }\end{array}$ & $\begin{array}{l}\text { High Park } \\
\text { Swansea }\end{array}$ & No & Yes & n/a & 1.5 & Always & 0.5 & 1.0 & 1.5 & $n / a$ & $R$ & D & $R$ & WD & WD & $n / a$ \\
\hline 4 & $\begin{array}{l}\text { 70's OBC } \\
\text { Single } \\
\text { detached }\end{array}$ & Forest Hill North & No & No & $n / a$ & & Always & & 0.3 & 0.3 & $n / a$ & $R$ & $N$ & $N$ & WD & WD & $n / a$ \\
\hline
\end{tabular}




\section{Survey Data for 1970s OBC Semi-Detached Houses}

Housing Inspection Data: Survey Result (1970s OBC Semi-detached houses)

\begin{tabular}{|c|c|c|c|c|c|c|c|c|c|c|c|c|c|}
\hline & \multirow[b]{2}{*}{ House Type } & \multirow[b]{2}{*}{ Neighbourhood } & \multirow[b]{2}{*}{ Shape } & \multicolumn{2}{|c|}{ Footprint } & \multirow[b]{2}{*}{$\begin{array}{l}\text { Area } \\
(\mathrm{m} 2)\end{array}$} & \multirow[b]{2}{*}{ Structure } & \multirow[b]{2}{*}{ Cladding } & \multirow[b]{2}{*}{ Roof } & \multicolumn{4}{|l|}{ Height(m) } \\
\hline & & & & $\begin{array}{l}\text { Width } \\
\text { (m) }\end{array}$ & $\begin{array}{l}\text { length } \\
\text { (m) }\end{array}$ & & & & & Basement & $\begin{array}{l}\text { Above } \\
\text { Grade }\end{array}$ & $\begin{array}{l}\text { Storey } \\
1\end{array}$ & $\begin{array}{l}\text { Storey } \\
2\end{array}$ \\
\hline 1 & 1970s OBC & High Park Swansea & Rectangle & 7.2 & 10.6 & 209.5 & Wood & Brick & Shingle & 2.4 & 1.2 & 2.8 & 2.8 \\
\hline 2 & 1970s OBC & Junction Area & Rectangle & 5.9 & 15.8 & 260.2 & Wood & Brick & Shingle & 2.4 & 1.0 & 2.7 & 2.7 \\
\hline \multirow[t]{2}{*}{3} & 1970s OBC & Junction Area & Rectangle & 5.3 & 13.9 & 201.5 & Wood & Brick & Shingle & 2.3 & 1.4 & 2.7 & 2.6 \\
\hline & \multicolumn{3}{|c|}{ Average or Typical Characteristics } & 6.1 & 13.4 & 223.7 & Wood & Brick & Shingle & 2.4 & 1.2 & 2.7 & 2.7 \\
\hline
\end{tabular}

\begin{tabular}{|l|l|l|}
\hline HVAC System & Thermostat Location & Occupancy number \\
\hline Forced Air Gas & Main Hallway & 4 \\
\hline Electric Heating \& Cooling & Living Room & 1 \\
\hline Forced Air Gas & Dining Room & 4 \\
\hline Forced Air Gas & Dining Room & 3.0 \\
\hline
\end{tabular}

\begin{tabular}{|l|l|l|l|l|l|}
\hline & \multicolumn{4}{|l}{ Window to Wall Ratio } & Glazing \\
\hline & Front & Back & side 1 & side 2 & \\
\hline 1 & $28 \%$ & $25 \%$ & $10 \%$ & $0 \%$ & Double glaze \\
\hline 2 & $30 \%$ & $20 \%$ & $7 \%$ & $0 \%$ & Double glaze \\
\hline 3 & $32 \%$ & $25 \%$ & $15 \%$ & $0 \%$ & Double glaze \\
\hline & $\mathbf{3 0} \%$ & $\mathbf{2 3} \%$ & $\mathbf{1 1 \%}$ & $\mathbf{0} \%$ & Double glaze \\
\hline
\end{tabular}




\begin{tabular}{|c|c|c|c|c|c|c|c|c|c|c|c|c|c|c|}
\hline & \multicolumn{10}{|c|}{ Window Frame Data $(\mathrm{cm})$} & \multicolumn{4}{|l|}{ Door } \\
\hline & $\begin{array}{l}\text { Frame } \\
\text { Width }\end{array}$ & $\begin{array}{l}\text { Divider } \\
\text { Type }\end{array}$ & $\begin{array}{l}\text { Divider } \\
\text { width }\end{array}$ & $\begin{array}{l}\# \\
\text { Horizontal }\end{array}$ & $\begin{array}{l}\# \\
\text { Vertical }\end{array}$ & $\begin{array}{l}\text { Divider } \\
\text { Projection }\end{array}$ & $\begin{array}{l}\text { Sill } \\
\text { Depth }\end{array}$ & $\begin{array}{l}\text { Sill } \\
\text { Material }\end{array}$ & $\begin{array}{l}\text { Reveal } \\
\text { Depth }\end{array}$ & $\begin{array}{l}\text { Reveal } \\
\text { Material }\end{array}$ & $\begin{array}{l}\text { Front } \\
\text { Door } \\
\text { (m2) }\end{array}$ & $\begin{array}{l}\text { Side } \\
\text { door }\end{array}$ & $\begin{array}{l}\text { Back } \\
\text { door }\end{array}$ & Insulation \\
\hline 1 & 8 & Lite & 3.8 & 1 & 1 & 1.2 & 12.7 & Wood & 12.7 & Wood & 1.88 & 1.69 & 2.6 & Insulated \\
\hline 2 & 10.16 & Lite & 5.1 & 1 & 1 & 2.5 & 11.4 & Wood & 11.4 & Wood & 1.9 & 1.6 & 2.9 & Insulated \\
\hline \multirow[t]{2}{*}{3} & 8.89 & Lite & 6.5 & 2 & $\mathrm{n} / \mathrm{a}$ & 1.0 & 10.2 & Wood & 10.2 & Wood & 1.89 & 1.69 & 2.8 & Insulated \\
\hline & 9.02 & Lite & 5.1 & 1.3 & 1 & 1.6 & 11.4 & Wood & 11.4 & Wood & 1.89 & 1.66 & 2.77 & Insulated \\
\hline
\end{tabular}

\begin{tabular}{|c|c|c|c|c|c|c|c|c|c|c|c|c|c|c|c|c|c|}
\hline & \multirow[b]{2}{*}{ House Type } & \multirow[b]{2}{*}{ Neighbourhood } & \multirow{2}{*}{$\begin{array}{c}\text { Renovation } \\
\text { done by } \\
\text { current } \\
\text { owner }\end{array}$} & \multirow{2}{*}{$\begin{array}{c}\text { Renovation } \\
\text { done } \\
\text { Previously }\end{array}$} & \multicolumn{7}{|c|}{ Use of Appliances (hours/per day) } & \multicolumn{6}{|c|}{ Appliances (time of use- D, N, WD, WN, R) } \\
\hline & & & & & $\begin{array}{l}\text { Kitchen } \\
\text { Fan }\end{array}$ & Stove & Fridge & $\begin{array}{c}\text { Dish } \\
\text { washer }\end{array}$ & $\begin{array}{c}\text { cloth } \\
\text { washer }\end{array}$ & $\begin{array}{l}\text { cloth } \\
\text { dryer }\end{array}$ & Others & $\begin{array}{l}\text { Kitchen } \\
\text { Fan }\end{array}$ & Stove & \begin{tabular}{|c|} 
Dish \\
washer
\end{tabular} & $\begin{array}{l}\text { cloth } \\
\text { washer }\end{array}$ & $\begin{array}{l}\text { cloth } \\
\text { dryer }\end{array}$ & Others \\
\hline 1 & $\begin{array}{c}70 \text { 's OBC Semi- } \\
\text { detached }\end{array}$ & $\begin{array}{c}\text { Runnymede-Bloor } \\
\text { West Village }\end{array}$ & No & No & $\mathrm{n} / \mathrm{a}$ & 2 & Always & $\mathrm{n} / \mathrm{a}$ & 0.5 & 0.5 & $\mathrm{n} / \mathrm{a}$ & $\mathrm{R}$ & $\mathrm{D}, \mathrm{WD}$ & $\mathrm{R}$ & WD & WD & $\mathrm{n} / \mathrm{a}$ \\
\hline 2 & $\begin{array}{l}\text { 70's OBC Semi- } \\
\text { detached }\end{array}$ & Junction Area & Yes & No & $\mathrm{n} / \mathrm{a}$ & 1 & Always & 0.5 & 0.5 & 0.5 & $\mathrm{n} / \mathrm{a}$ & $\mathrm{N}, \mathrm{WN}$ & $\mathrm{D}, \mathrm{N}, \mathrm{WD}, \mathrm{WN}$ & $\mathrm{N}, \mathrm{WN}$ & $\mathrm{N}, \mathrm{WD}$ & $\mathrm{N}, \mathrm{WD}$ & $\mathrm{n} / \mathrm{a}$ \\
\hline 3 & $\begin{array}{l}\text { 70's OBC Semi- } \\
\text { detached }\end{array}$ & Junction Area & Yes & No & 0.5 & 1 & Always & 2 & 1.0 & 1.0 & $\mathrm{n} / \mathrm{a}$ & $\mathrm{D}, \mathrm{WD}, \mathrm{WN}$ & $\mathrm{D}, \mathrm{WD}, \mathrm{WN}$ & $\mathrm{D}, \mathrm{WN}$ & $\mathrm{D}, \mathrm{WD}$ & $\mathrm{D}, \mathrm{WD}$ & $\mathrm{n} / \mathrm{a}$ \\
\hline
\end{tabular}


Appendix E: Energy Bill Data for 70s Single Detached \& Semi-Detached Houses Energy Bill Data (2014): 1970s OBC Single Detached House

\begin{tabular}{|c|c|c|c|c|c|c|c|c|c|c|}
\hline \multicolumn{5}{|c|}{ Study $1\left(278.7 \mathrm{~m}^{2}\right)$ (collected from energy bills) } & \multicolumn{2}{|c|}{$\begin{array}{l}\text { Study } 2\left(241.54 \mathrm{~m}^{2}\right) \\
\text { (collected from } \\
\text { survey questionnaire) }\end{array}$} & \multicolumn{2}{|c|}{$\begin{array}{lrr}\text { Study } & 3 & (265.2 \\
\left.\mathrm{m}^{2}\right) & \text { (collected } \\
\text { from } & \text { survey } \\
\text { questionnaire) } & \\
\end{array}$} & \multicolumn{2}{|c|}{$\begin{array}{l}\text { Study } 4\left(257.4 \mathrm{~m}^{2} \text { ) }\right. \\
\text { (collected from } \\
\text { survey } \\
\text { questionnaire) }\end{array}$} \\
\hline \multicolumn{2}{|l|}{ ELECTRICITY } & \multirow[b]{2}{*}{$\begin{array}{l}\text { Billing } \\
\text { period } \\
(2014) \\
\end{array}$} & \multirow{2}{*}{$\frac{\text { GAS }}{\mathrm{m} 3}$} & \multirow[b]{2}{*}{ GJ } & \multirow{2}{*}{$\begin{array}{l}\text { ELECTRICI } \\
\text { TY } \\
\mathrm{kWh}\end{array}$} & \multirow{2}{*}{$\frac{\text { GAS }}{\mathrm{m} 3}$} & \multirow{2}{*}{$\begin{array}{l}\text { ELECTRIC } \\
\text { ITY } \\
\mathrm{kWh}\end{array}$} & \multirow{2}{*}{$\begin{array}{l}\text { GA } \\
\mathrm{s} \\
\mathrm{m} 3\end{array}$} & \multirow{2}{*}{$\begin{array}{l}\text { ELECTRIC } \\
\text { ITY } \\
\mathrm{kWh}\end{array}$} & \multirow{2}{*}{$\begin{array}{l}\text { GAS } \\
\mathrm{m} 3\end{array}$} \\
\hline Billing period & kWh & & & & & & & & & \\
\hline \multirow{2}{*}{$\begin{array}{lr}\text { Dec } \quad 13, \\
2013-\quad \text { Feb } \\
14,2014 \\
\end{array}$} & 2943 & January & 736 & 28.0 & 1413 & 627 & 670 & 393 & 1490 & 550 \\
\hline & & February & 641 & 24.4 & & 641 & & 370 & & 450 \\
\hline \multirow{2}{*}{$\begin{array}{l}\text { Feb 14- Apl } \\
15\end{array}$} & 2673 & March & 281 & 10.7 & 1301 & 413 & 473 & 457 & 1071 & 350 \\
\hline & & April & 199 & 7.6 & & 380 & & 159 & & 350 \\
\hline \multirow{2}{*}{$\begin{array}{l}\text { Apl 15-June } \\
17\end{array}$} & 2912 & May & 188 & 7.1 & & 128 & 335 & 35 & 717 & 180 \\
\hline & & June & 22 & 0.8 & & 18 & & 14 & & 80 \\
\hline \multirow{2}{*}{$\begin{array}{l}\text { June } \\
\text { Aug } 16-\end{array}$} & 2991 & July & 12 & 0.5 & 1581 & 61 & 396 & 47 & 818 & 50 \\
\hline & & August & 26 & 1.0 & & 50 & & 16 & & 50 \\
\hline \multirow{2}{*}{$\begin{array}{l}\text { Aug } 15-\text { Oct } \\
16\end{array}$} & 3006 & $\begin{array}{l}\text { Septembe } \\
r\end{array}$ & 7 & 0.3 & 1249 & 66 & 431 & 38 & 907 & 150 \\
\hline & & October & 216 & 8.2 & & 103 & & 185 & & 300 \\
\hline \multirow[b]{2}{*}{$\begin{array}{l}\text { Oct 16- Dec } \\
15\end{array}$} & 2881 & $\begin{array}{l}\text { Novembe } \\
\mathrm{r}\end{array}$ & 325 & 12.4 & 1494 & 373 & 574 & 184 & 1059 & 350 \\
\hline & & $\begin{array}{l}\text { Decembe } \\
r\end{array}$ & 555 & 21.1 & & 359 & & 293 & & 450 \\
\hline
\end{tabular}

Energy Bill Data (2014): 1970s OBC Semi- Detached House

\begin{tabular}{|c|c|c|c|c|c|c|c|}
\hline \multicolumn{3}{|c|}{$\begin{array}{l}\text { Study } 1\left(228.72 \mathrm{~m}^{2}\right) \text { ) (collected } \\
\text { from energy bills) }\end{array}$} & \multicolumn{3}{|l|}{ Study $2\left(279.33 \mathrm{~m}^{2}\right)$} & \multicolumn{2}{|c|}{ Study $3\left(246.42 \mathrm{~m}^{2}\right)$} \\
\hline & \multirow{2}{*}{$\frac{\text { GAS }}{\mathrm{m} 3}$} & \multirow[b]{2}{*}{ GJ } & \multicolumn{2}{|l|}{ ELECTRICITY } & \multirow{2}{*}{$\begin{array}{l}\text { GAS } \\
\mathrm{m} 3\end{array}$} & \multirow{2}{*}{$\begin{array}{l}\text { ELECTRICITY } \\
\mathrm{kWh}\end{array}$} & \multirow{2}{*}{$\frac{\mathrm{GAS}}{\mathrm{m} 3}$} \\
\hline & & & Billing period & $\mathrm{kWh}$ & & & \\
\hline January & 485 & 18.4 & Nov 22, 2013-Jan 24, 2014 & 6337.66 & & & \\
\hline February & 458 & 17.4 & \multirow[t]{2}{*}{ Jan 24- Mar 25} & 6493.3 & $=$ & 113.872 & $=$ \\
\hline March & 302 & 11.5 & & & & & \\
\hline April & 177 & 6.7 & \multirow[t]{2}{*}{ Mar 25- May 27} & 2354.31 & & 359.697 & \\
\hline May & 72 & 2.7 & & & & & \\
\hline June & 2 & 0.1 & May 27-July 24 & 436.829 & & 1398.689 & \\
\hline July & 0 & 0.0 & & & & & \\
\hline August & 0 & 0.0 & July $24-$ Sep 24 & 497.009 & & 707.285 & \\
\hline September & 34 & 1.3 & & & & & \\
\hline October & 109 & 4.1 & & & & 654.726 & \\
\hline November & & & & & & & \\
\hline December & & & & & & 1179.769 & \\
\hline
\end{tabular}




\section{Appendix F: OBC 2012, SB-12}

Table 2.1.1.2.A

ZONE 1 - Compliance Packages for Space Heating Equipment with AFUE $\geq 90 \%$

Forming Part of Sentence 2.1.1.2.(1)

\begin{tabular}{|c|c|c|c|c|c|c|c|c|c|c|c|c|c|}
\hline \multirow{2}{*}{ Component } & \multicolumn{13}{|c|}{ Compliance Package } \\
\hline & A & B & C & D & $E$ & $\mathrm{~F}$ & $G$ & $\mathrm{H}$ & I & $\mathrm{J}$ & $K^{[3]}$ & $L^{(4)}$ & $M^{(5)}$ \\
\hline $\begin{array}{l}\text { Ceiling with Attic Space } \\
\text { Minimum RSI (R)-Value }^{(1)}\end{array}$ & $\begin{array}{l}8.81 \\
\text { (R50) }\end{array}$ & $\begin{array}{r}8.81 \\
\text { (R50) }\end{array}$ & $\begin{array}{l}8.81 \\
\text { (R50) }\end{array}$ & $\begin{array}{l}8.81 \\
\text { (R50) }\end{array}$ & $\begin{array}{c}8.81 \\
\text { (R50) }\end{array}$ & $\begin{array}{l}8.81 \\
\text { (R50) }\end{array}$ & $\begin{array}{l}8.81 \\
\text { (R50) }\end{array}$ & $\begin{array}{l}8.81 \\
\text { (R50) }\end{array}$ & $\begin{array}{l}8.81 \\
\text { (R50) }\end{array}$ & $\begin{array}{c}8.81 \\
\text { (R50) }\end{array}$ & $\begin{array}{l}8.81 \\
\text { (R50) }\end{array}$ & $\begin{array}{l}8.81 \\
\text { (R50) }\end{array}$ & $\begin{array}{l}8.81 \\
\text { (R50) }\end{array}$ \\
\hline $\begin{array}{l}\text { Ceiling Without Attic Space } \\
\text { Minimum RSI (R)-Value }{ }^{(1)}\end{array}$ & $\begin{array}{l}5.46 \\
\text { (R31) }\end{array}$ & $\begin{array}{l}5.46 \\
\text { (R31) }\end{array}$ & $\begin{array}{l}5.46 \\
\text { (R31) }\end{array}$ & $\begin{array}{l}5.46 \\
\text { (R31) }\end{array}$ & $\begin{array}{l}5.46 \\
\text { (R31) }\end{array}$ & $\begin{array}{l}5.46 \\
\text { (R31) }\end{array}$ & $\begin{array}{l}5.46 \\
\text { (R31) }\end{array}$ & $\begin{array}{l}5.46 \\
\text { (R31) }\end{array}$ & $\begin{array}{l}5.46 \\
\text { (R31) }\end{array}$ & $\begin{array}{l}5.46 \\
\text { (R31) }\end{array}$ & $\begin{array}{l}5.46 \\
\text { (R31) }\end{array}$ & $\begin{array}{l}5.46 \\
\text { (R31) }\end{array}$ & $\begin{array}{l}5.46 \\
\text { (R31) }\end{array}$ \\
\hline $\begin{array}{l}\text { Exposed Floor } \\
\text { Minimum RSI (R)-Value }{ }^{(1)}\end{array}$ & $\begin{array}{l}5.46 \\
\text { (R31) }\end{array}$ & $\begin{array}{l}5.46 \\
\text { (R31) }\end{array}$ & $\begin{array}{l}5.46 \\
\text { (R31) }\end{array}$ & $\begin{array}{l}5.46 \\
\text { (R31) }\end{array}$ & $\begin{array}{l}5.46 \\
\text { (R31) }\end{array}$ & $\begin{array}{l}5.46 \\
\text { (R31) }\end{array}$ & $\begin{array}{l}5.46 \\
\text { (R31) }\end{array}$ & $\begin{array}{l}5.46 \\
\text { (R31) }\end{array}$ & $\begin{array}{l}5.46 \\
\text { (R31) }\end{array}$ & $\begin{array}{l}5.46 \\
\text { (R31) }\end{array}$ & $\begin{array}{l}5.46 \\
\text { (R31) }\end{array}$ & $\begin{array}{l}5.46 \\
\text { (R31) }\end{array}$ & $\begin{array}{l}5.46 \\
\text { (R31) }\end{array}$ \\
\hline $\begin{array}{l}\text { Walls Above Grade } \\
\text { Minimum RSI (R)-Value }{ }^{(1)}\end{array}$ & $\begin{array}{l}4.23 \\
\text { (R24) }\end{array}$ & $\begin{array}{l}4.75 \\
\text { (R27) }\end{array}$ & $\begin{array}{l}4.75 \\
\text { (R27) }\end{array}$ & $\begin{array}{l}4.23 \\
(\mathrm{R} 24)\end{array}$ & $\begin{array}{l}4.23 \\
\text { (R24) }\end{array}$ & $\begin{array}{l}4.23 \\
\text { (R24) }\end{array}$ & $\begin{array}{l}4.23 \\
\text { (R24) }\end{array}$ & $\begin{array}{l}4.23 \\
\text { (R24) }\end{array}$ & $\begin{array}{l}3.87 \\
(\mathrm{R} 22)\end{array}$ & $\begin{array}{l}3.87 \\
(R 22)\end{array}$ & $\begin{array}{l}3.87 \\
(\mathrm{R} 22)\end{array}$ & $\begin{array}{l}4.23 \\
\text { (R24) }\end{array}$ & $\begin{array}{l}4.23 \\
(\mathrm{R} 24)\end{array}$ \\
\hline $\begin{array}{l}\text { BasementWalls } \\
\text { Minimum RSI (R)-Value }{ }^{(1)}\end{array}$ & $\begin{array}{l}3.52 \\
(\mathrm{R} 20)\end{array}$ & $\begin{array}{l}3.52 \\
(\mathrm{R} 20)\end{array}$ & $\begin{array}{l}3.52 \\
(\mathrm{R} 20)\end{array}$ & $\begin{array}{l}3.52 \\
(\mathrm{R} 20)\end{array}$ & $\begin{array}{c}3.52 \\
(\mathrm{R} 20)\end{array}$ & $\begin{array}{l}2.11 \\
(\mathrm{R} 12)\end{array}$ & $\begin{array}{l}2.11 \\
(\mathrm{R} 12)\end{array}$ & $\begin{array}{l}2.11 \\
\text { (R12) }\end{array}$ & $\begin{array}{l}3.52 \\
(\mathrm{R} 20)\end{array}$ & $\begin{array}{c}2.11 \\
(\mathrm{R} 12)\end{array}$ & $\begin{array}{l}3.87 \\
(\mathrm{R} 22)\end{array}$ & $\begin{array}{l}3.87 \\
(\mathrm{R} 22)\end{array}$ & $\begin{array}{l}3.52 \\
(\mathrm{R} 20)\end{array}$ \\
\hline $\begin{array}{l}\text { Below Grade Slab } \\
\text { Entire surface }>600 \mathrm{~mm} \\
\text { below grade } \\
\text { Minimum RSI (R)-Value }\end{array}$ & $\begin{array}{l}0.88 \\
(\mathrm{R} 5)\end{array}$ & - & - & - & - & - & - & - & - & - & - & - & - \\
\hline $\begin{array}{l}\text { Edge of Below Grade Slab } \\
\leq 600 \mathrm{~mm} \text { Below Grade } \\
\text { Minimum RSI (R)-Value }{ }^{(1)}\end{array}$ & $\begin{array}{l}1.76 \\
\text { (R10) }\end{array}$ & $\begin{array}{l}1.76 \\
\text { (R10) }\end{array}$ & $\begin{array}{l}1.76 \\
\text { (R10) }\end{array}$ & $\begin{array}{l}1.76 \\
\text { (R10) }\end{array}$ & $\begin{array}{c}1.76 \\
(\mathrm{R} 10)\end{array}$ & $\begin{array}{c}1.76 \\
(\mathrm{R} 10)\end{array}$ & $\begin{array}{c}1.76 \\
\text { (R10) }\end{array}$ & $\begin{array}{c}1.76 \\
\text { (R10) }\end{array}$ & $\begin{array}{l}1.76 \\
\text { (R10) }\end{array}$ & $\begin{array}{c}1.76 \\
(\mathrm{R} 10)\end{array}$ & $\begin{array}{c}1.76 \\
(\mathrm{R} 10)\end{array}$ & $\begin{array}{l}1.76 \\
(\mathrm{R} 10)\end{array}$ & $\begin{array}{r}1.76 \\
\text { (R10) }\end{array}$ \\
\hline $\begin{array}{l}\text { Heated Slab or } \\
\text { Slab } \leq 600 \mathrm{~mm} \text { below grade } \\
\text { Minimum RSI (R)-Value } \text { (1) }^{(1)}\end{array}$ & $\begin{array}{c}1.76 \\
(\mathrm{R} 10)\end{array}$ & $\begin{array}{c}1.76 \\
(\mathrm{R} 10)\end{array}$ & $\begin{array}{l}1.76 \\
\text { (R10) }\end{array}$ & $\begin{array}{l}1.76 \\
\text { (R10) }\end{array}$ & $\begin{array}{c}1.76 \\
\text { (R10) }\end{array}$ & $\begin{array}{l}1.76 \\
(\mathrm{R} 10)\end{array}$ & $\begin{array}{l}1.76 \\
(\mathrm{R} 10)\end{array}$ & $\begin{array}{l}1.76 \\
\text { (R10) }\end{array}$ & $\begin{array}{l}1.76 \\
\text { (R10) }\end{array}$ & $\begin{array}{c}1.76 \\
(\mathrm{R} 10)\end{array}$ & $\begin{array}{l}1.76 \\
(\mathrm{R} 10)\end{array}$ & $\begin{array}{l}1.76 \\
\text { (R10) }\end{array}$ & $\begin{array}{l}1.76 \\
\text { (R10) }\end{array}$ \\
\hline $\begin{array}{l}\text { Windows and Sliding Glass } \\
\text { Doors } \\
\text { Maximum U-Value }{ }^{(2)}\end{array}$ & 1.6 & 1.6 & 1.8 & 1.8 & 1.8 & 1.8 & 1.8 & 2 & 1.8 & 1.8 & 1.8 & 1.8 & 1.8 \\
\hline $\begin{array}{l}\text { Skylights } \\
\text { Maximum U-Value }{ }^{(2)}\end{array}$ & 2.8 & 2.8 & 2.8 & 2.8 & 2.8 & 2.8 & 2.8 & 2.8 & 2.8 & 2.8 & 2.8 & 2.8 & 2.8 \\
\hline $\begin{array}{l}\text { Space Heating Equipment } \\
\text { Minimum AFUE }\end{array}$ & $90 \%$ & $90 \%$ & $94 \%$ & $94 \%$ & $90 \%$ & $94 \%$ & $92 \%$ & $94 \%$ & $92 \%$ & $94 \%$ & $90 \%$ & $94 \%$ & $90 \%{ }^{(8)}$ \\
\hline $\begin{array}{l}\mathrm{HRV}^{(6),(7)} \\
\text { Minimum Efficiency }\end{array}$ & - & - & - & - & $55 \%$ & $60 \%$ & $60 \%$ & $70 \%$ & $55 \%$ & $60 \%$ & - & - & - \\
\hline $\begin{array}{l}\text { Domestic Hot Water Heater } \\
\text { Minimum EF }\end{array}$ & 0.57 & 0.57 & 0.62 & 0.67 & 0.57 & 0.57 & 0.62 & 0.67 & 0.62 & 0.67 & 0.57 & 0.57 & $0.80^{[8]}$ \\
\hline Column 1 & 2 & 3 & 4 & 5 & 6 & 7 & 8 & 9 & 10 & 11 & 12 & 13 & 14 \\
\hline
\end{tabular}




\section{Appendix G: Retrofit options for 70s OBC Single detached and Semi-detached Houses}

\section{LEVEL 1}

Section

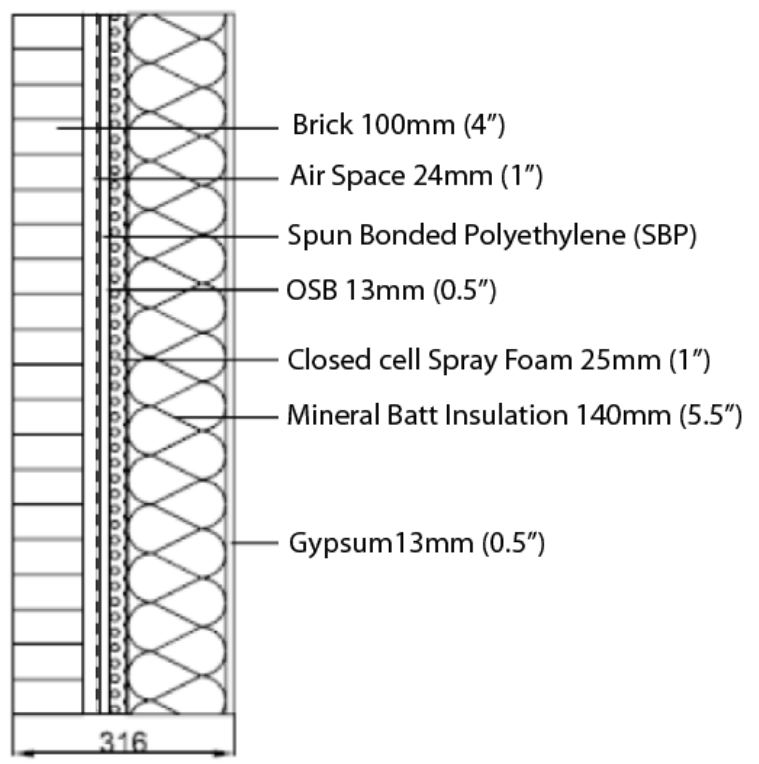

Plan

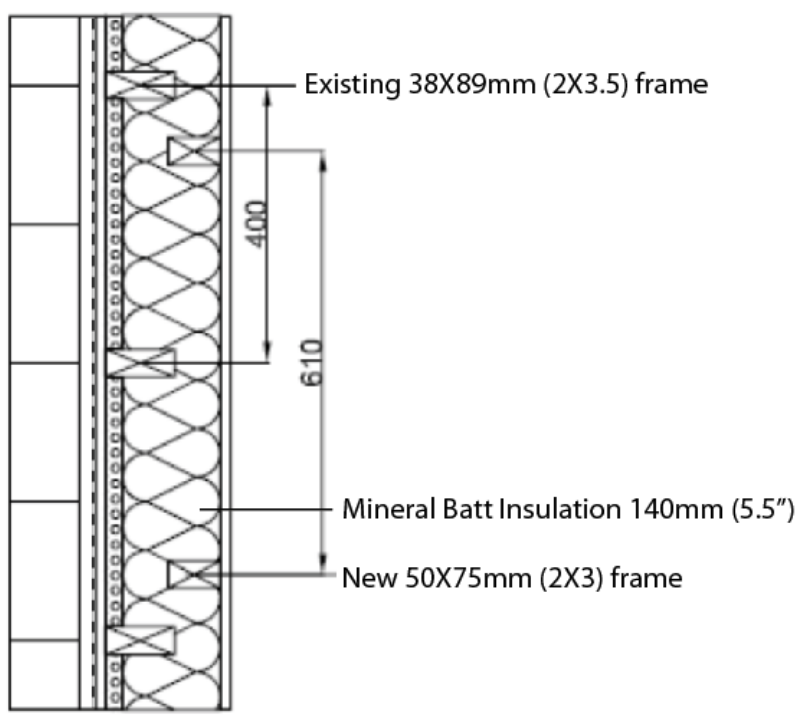

Exterior Wall Retrofit Level 1, RSI 4 (R 22) (Adapted from Jermyn D. 2014)
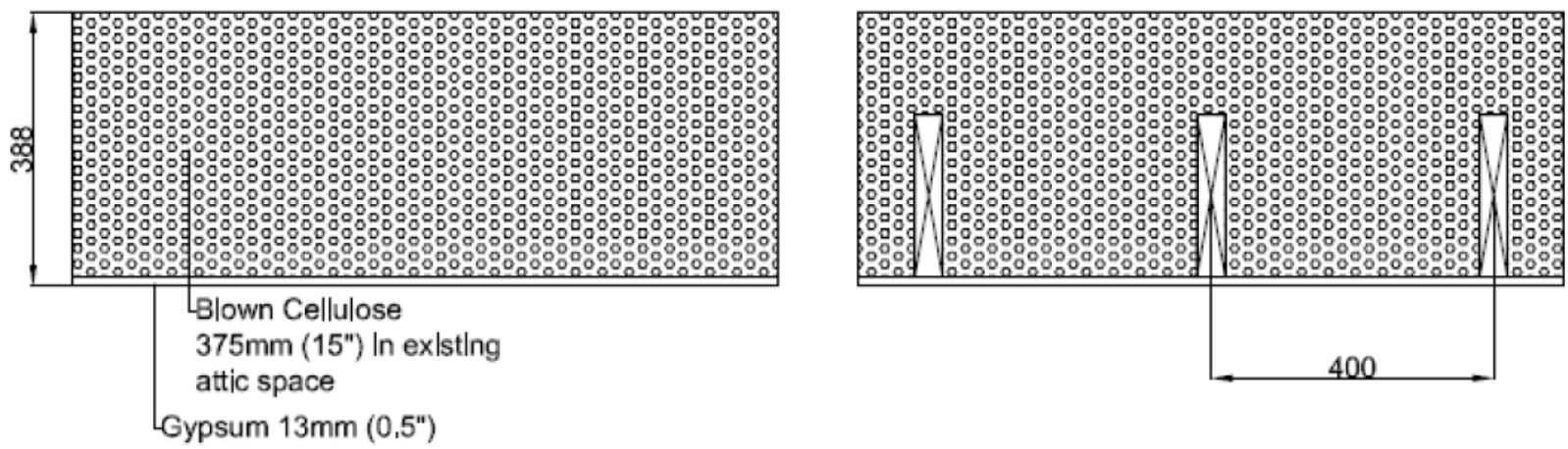

Attic Roof Retrofit Level 1, RSI 9 (R 50) (Adapted from Jermyn D. 2014) 
Section

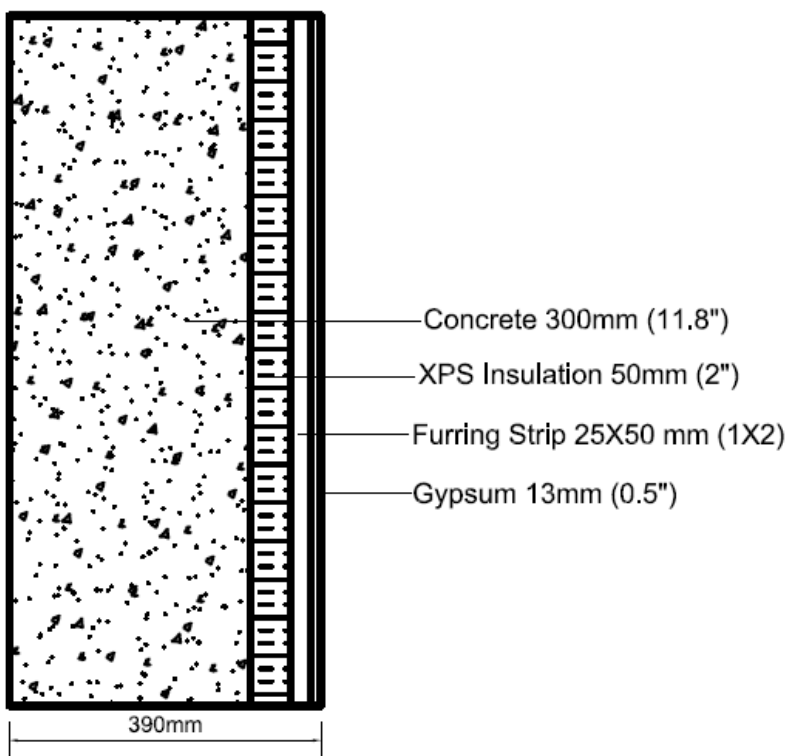

Plan

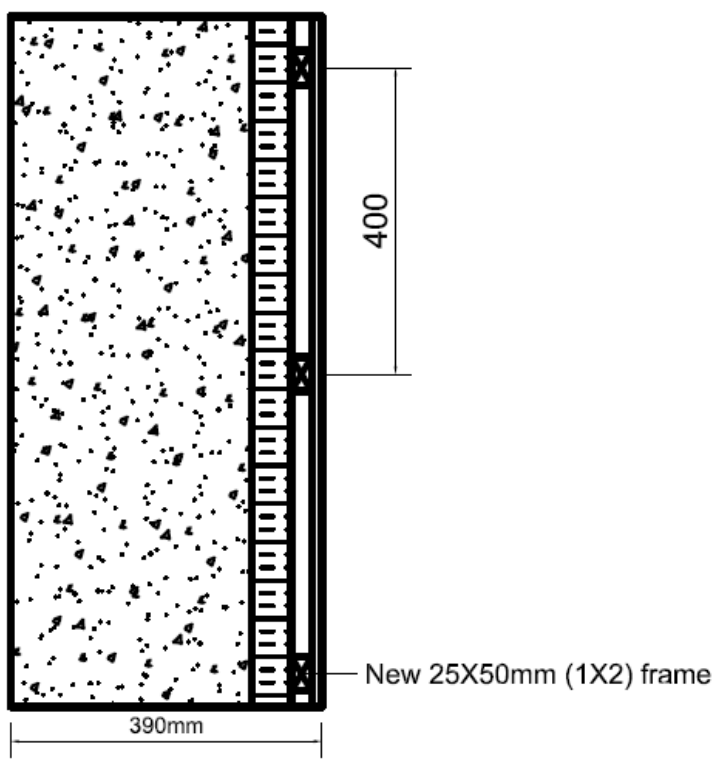

Basement Wall Retrofit Level 1, RSI 2 (R 12) (Adapted from Jermyn D. 2014)

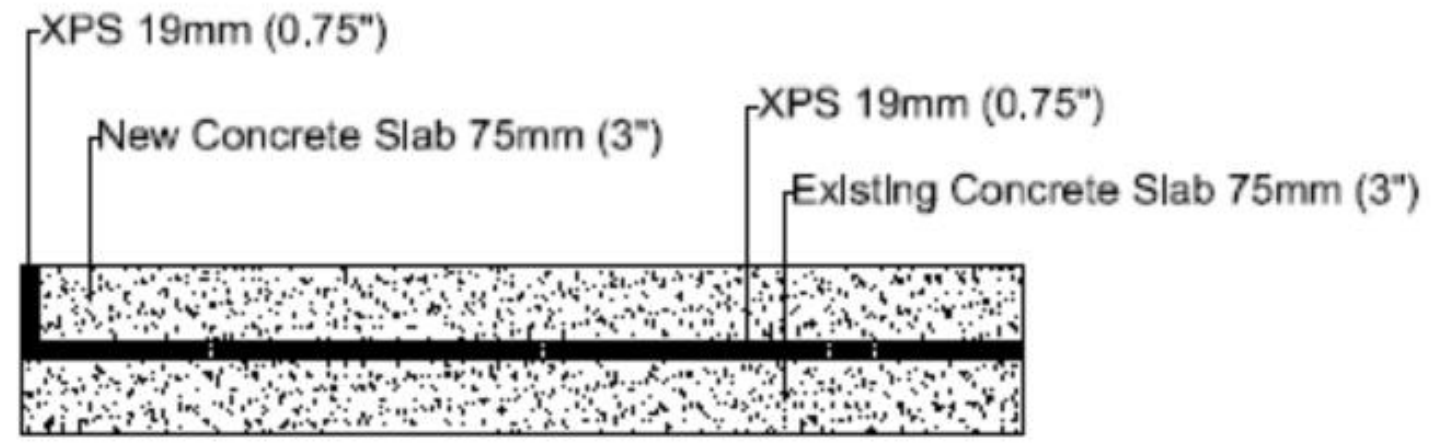

Slab Level 1, RSI 0.75 (R 5) (Adapted from Jermyn D. 2014)

Others:

Cooling COP-3.375

Heating gas furnace- $90 \%$ efficient

Heat Recovery Ventilator included. Sensible \& latent heat exchanger (air to air)

Window:

U value-1.9

R- $0.53 \mathrm{~m}^{2} \mathrm{~K} / \mathrm{W}$

Construction:

Low E glass $5 \mathrm{~mm}$

$12 \mathrm{~mm}$ air filled

Clear glass $5 \mathrm{~mm}$ 


\section{LEVEL 2}

Section

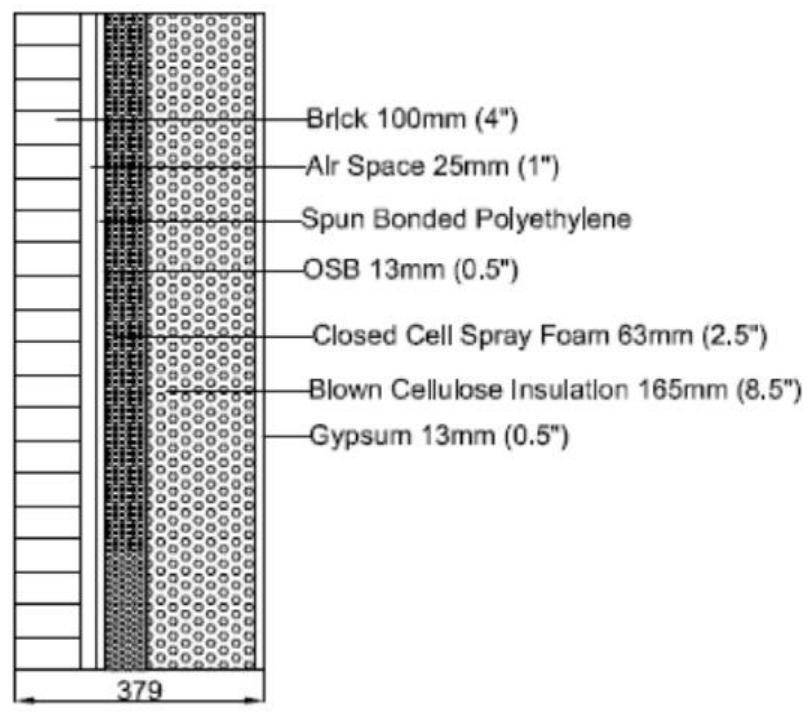

Plan

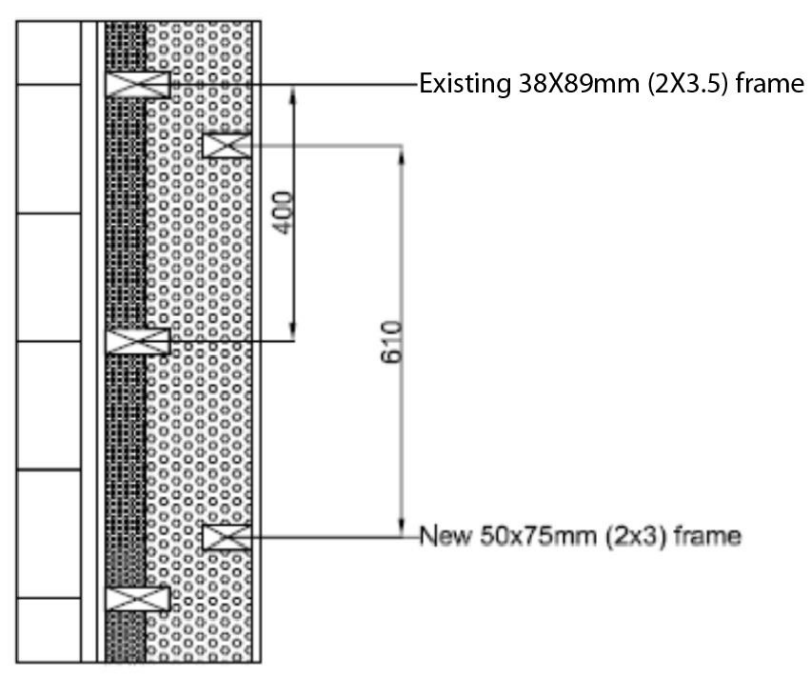

Exterior Wall Retrofit Level 2, RSI 6 (R 35) (Adapted from Jermyn D. 2014)

Section (long)

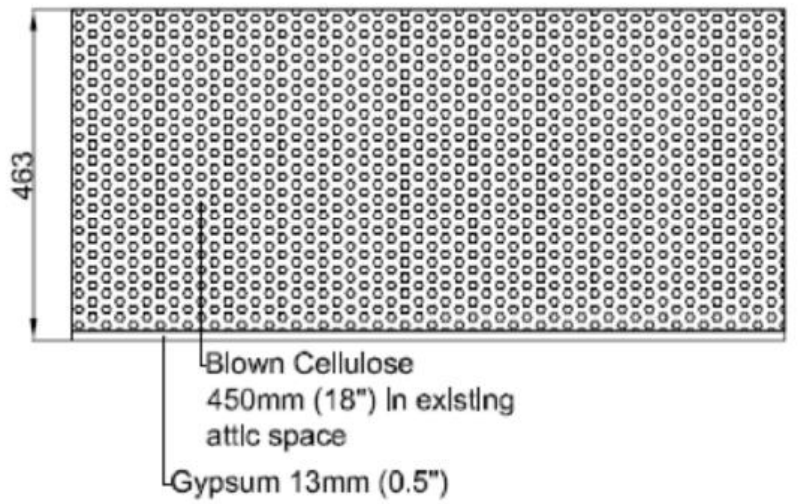

Section (transverse)

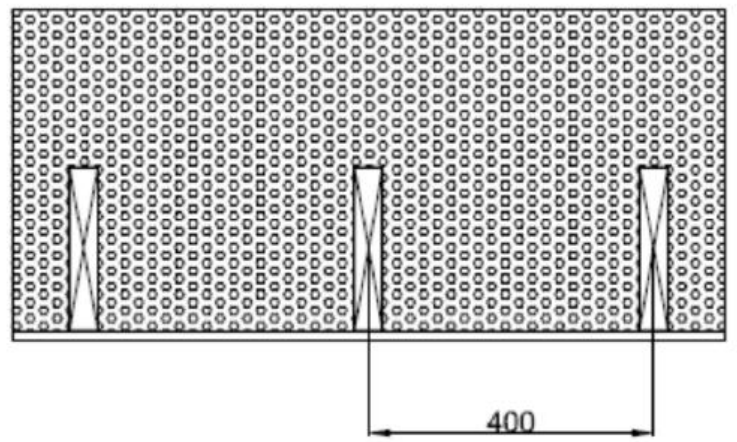

Attic Roof Retrofit Level 2, RSI 10.5 (R 60) (Adapted from Jermyn D. 2014) 

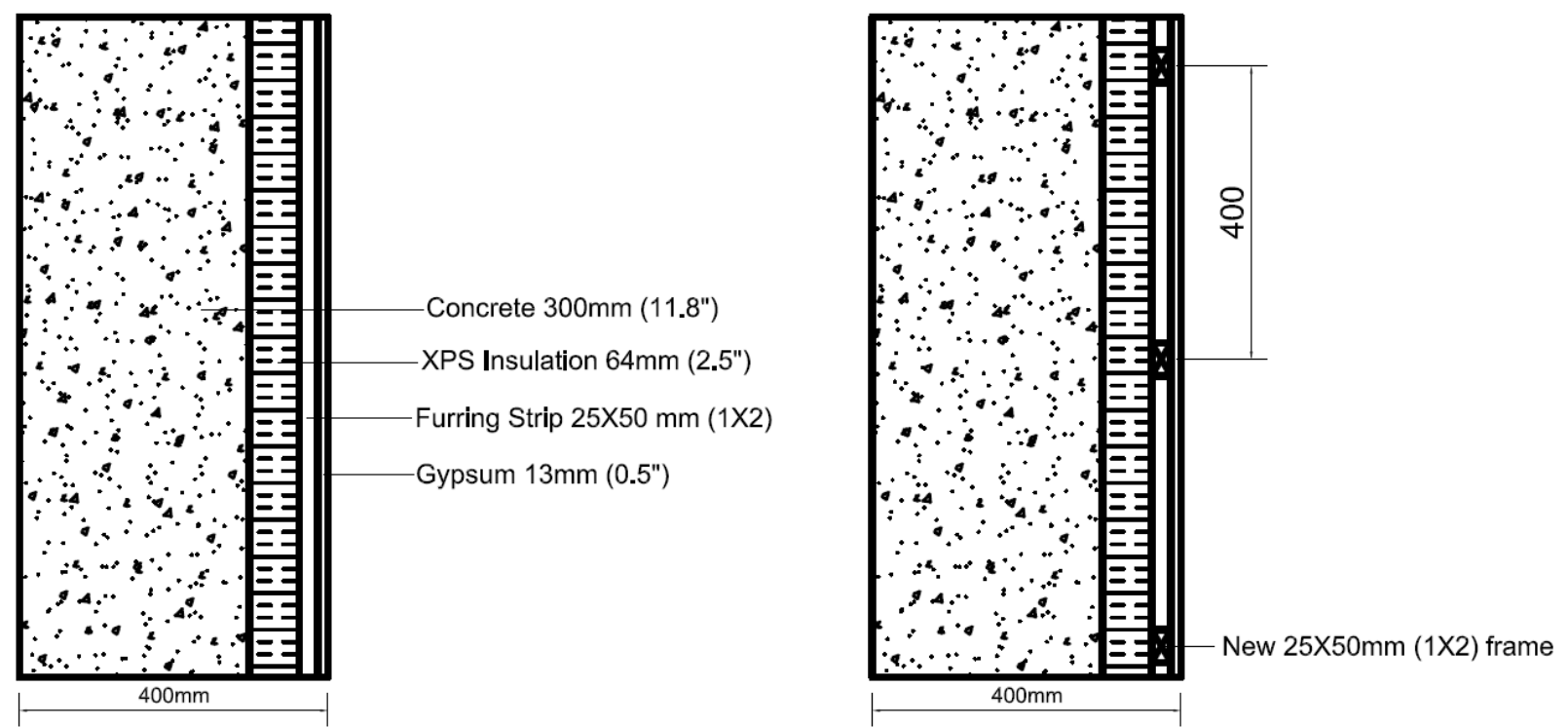

Basement Wall Retrofit Level 2, RSI 3 (R 17) (Adapted from Jermyn D. 2014)

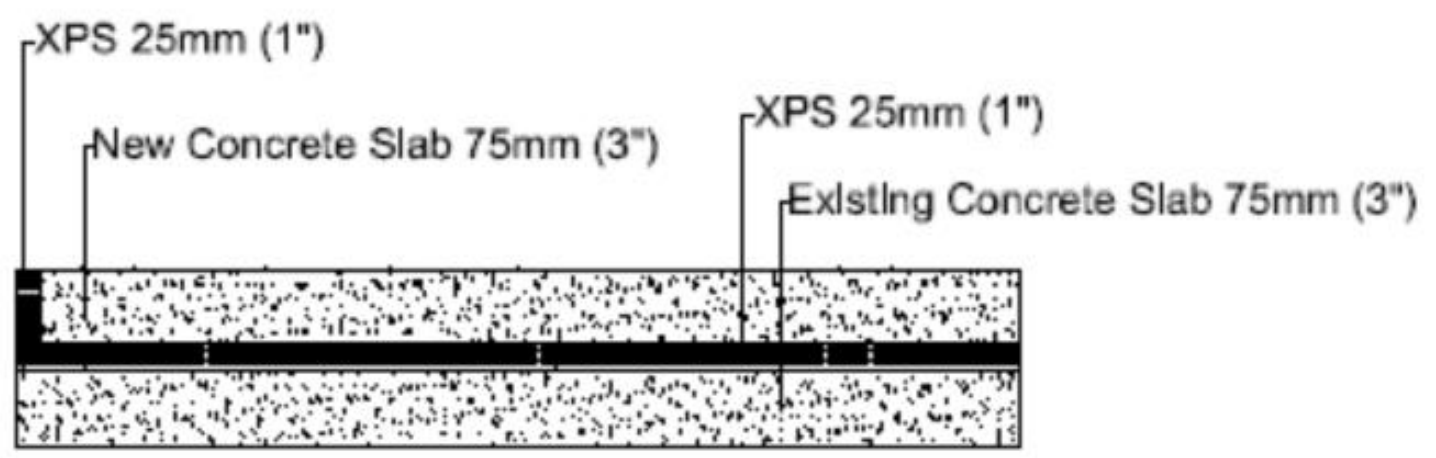

Slab Level 2, RSI 1 (R 6) (Adapted from Jermyn D. 2014)

Others

Cooling COP-3.525

Heating gas furnace-94\% efficient

Window:

$U$ value-1.2

$\mathrm{R}-0.83 \mathrm{~m}^{2} \mathrm{~K} / \mathrm{W}$

Construction:

Low $\mathrm{E}$ glass $5 \mathrm{~mm}$

$12 \mathrm{~mm}$ argon filled

Low $\mathrm{E}$ glass $5 \mathrm{~mm}$ 


\section{LEVEL 3}

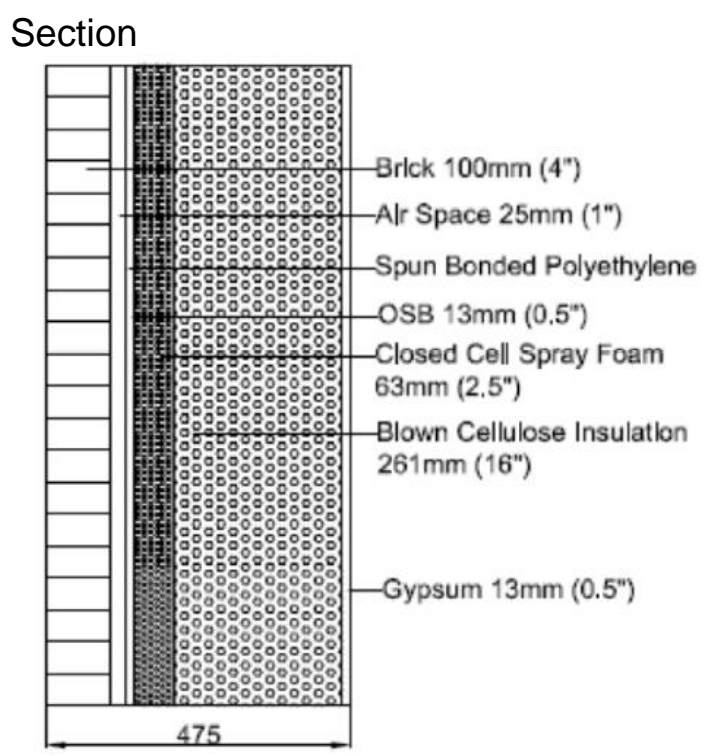

\section{Plan}

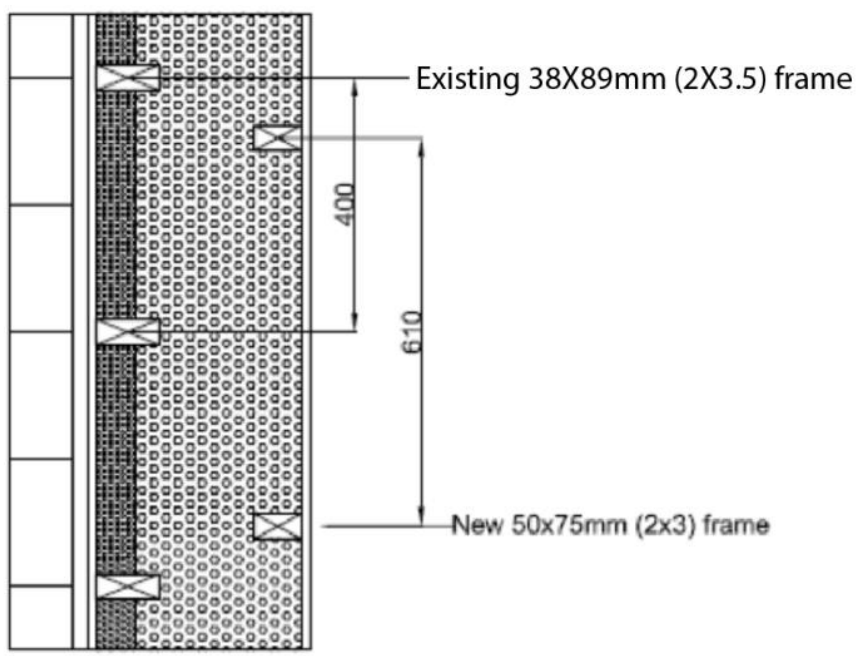

Exterior Wall Retrofit Level 3, RSI 10 (R 57) (Adapted from Jermyn D. 2014)

\section{Section (long)}

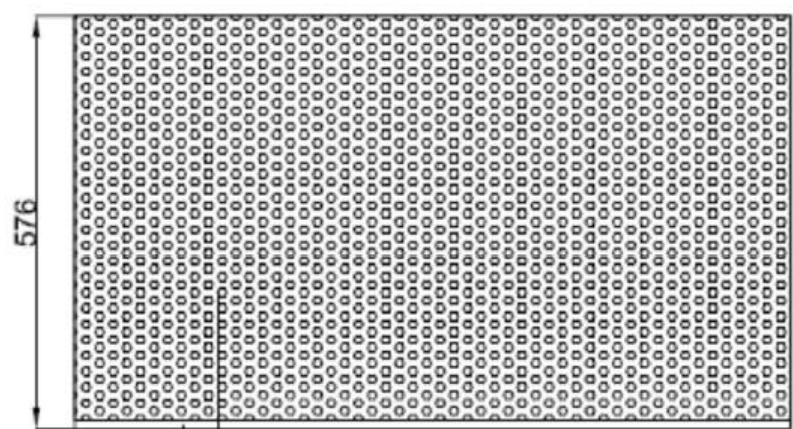

Blown Cellulose

$563 \mathrm{~mm}\left(22.5^{\prime \prime}\right)$ In existing

attic space

Gypsum 13mm (0.5")
Section (transverse)

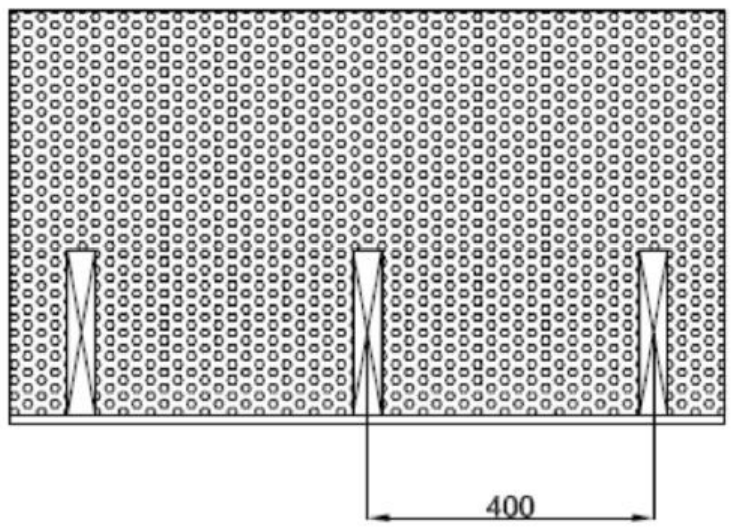

Attic Roof Retrofit Level 3, RSI 13 (R 75) (Adapted from Jermyn D. 2014) 
Section

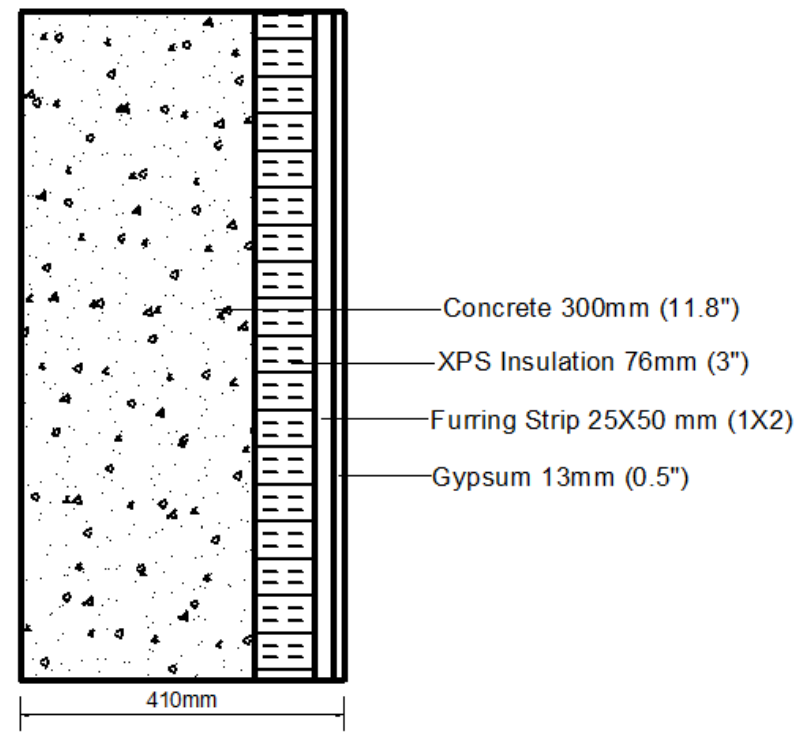

Plan

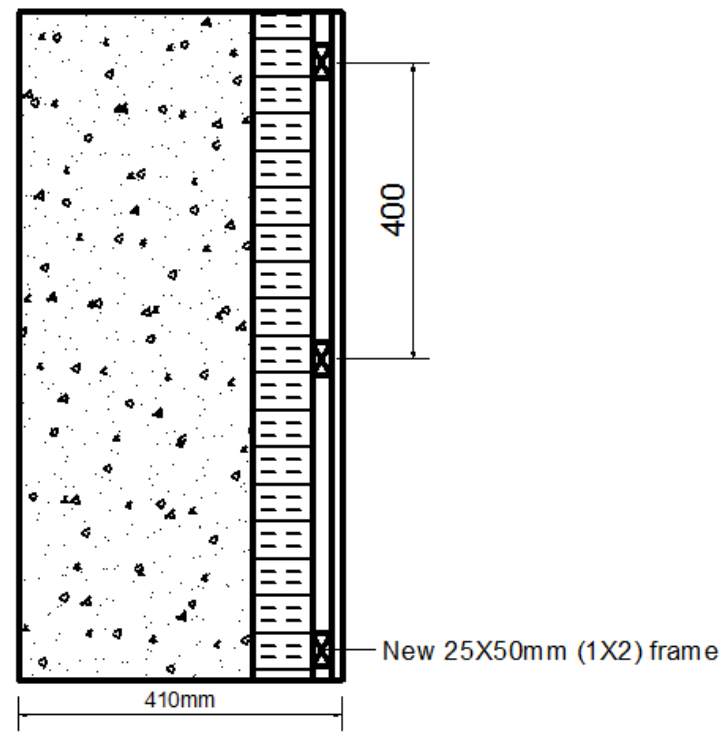

Basement Wall Retrofit Level 3, RSI 3.5 (R 20) (Adapted from Jermyn D. 2014)

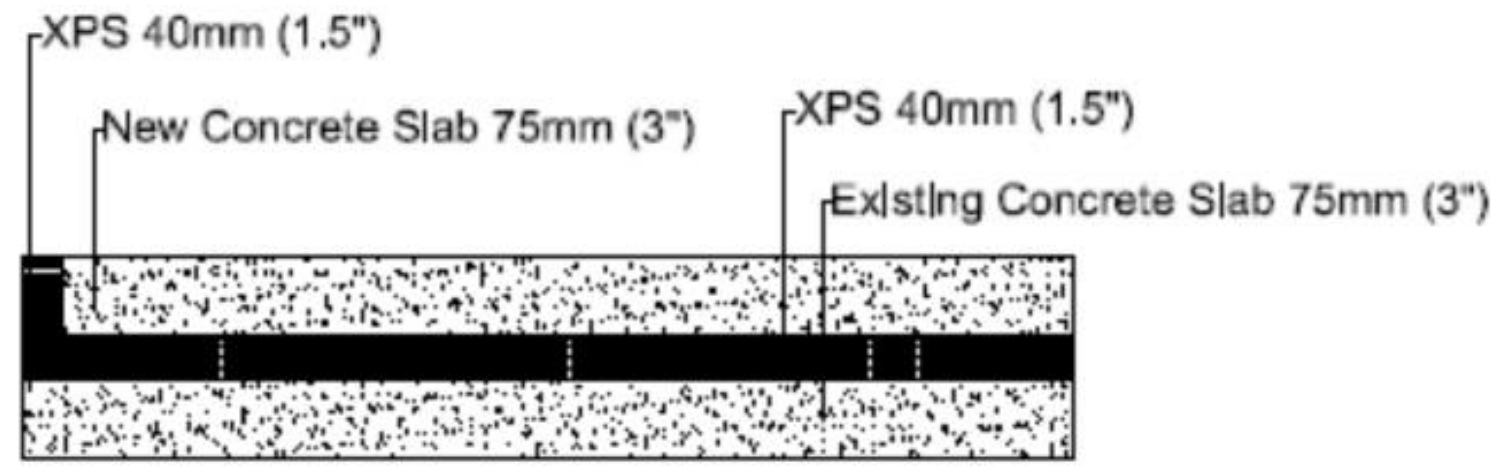

Slab Level 3, RSI 1.75 (R 10) (Adapted from Jermyn D. 2014)

Others

Cooling COP-3.637

Heating gas furnace- $97 \%$ efficient

Window:

U value-1

R- $1 \mathrm{~m}^{2} \mathrm{~K} / \mathrm{W}$

Construction:

Clear glass $4 \mathrm{~mm}$

$12 \mathrm{~mm}$ air filled

Clear glass $4 \mathrm{~mm}$

$12 \mathrm{~mm}$ air filled

Clear glass $4 \mathrm{~mm}$ 


\section{Appendix H: Condensation and Decay Hours for retrofit assemblies}

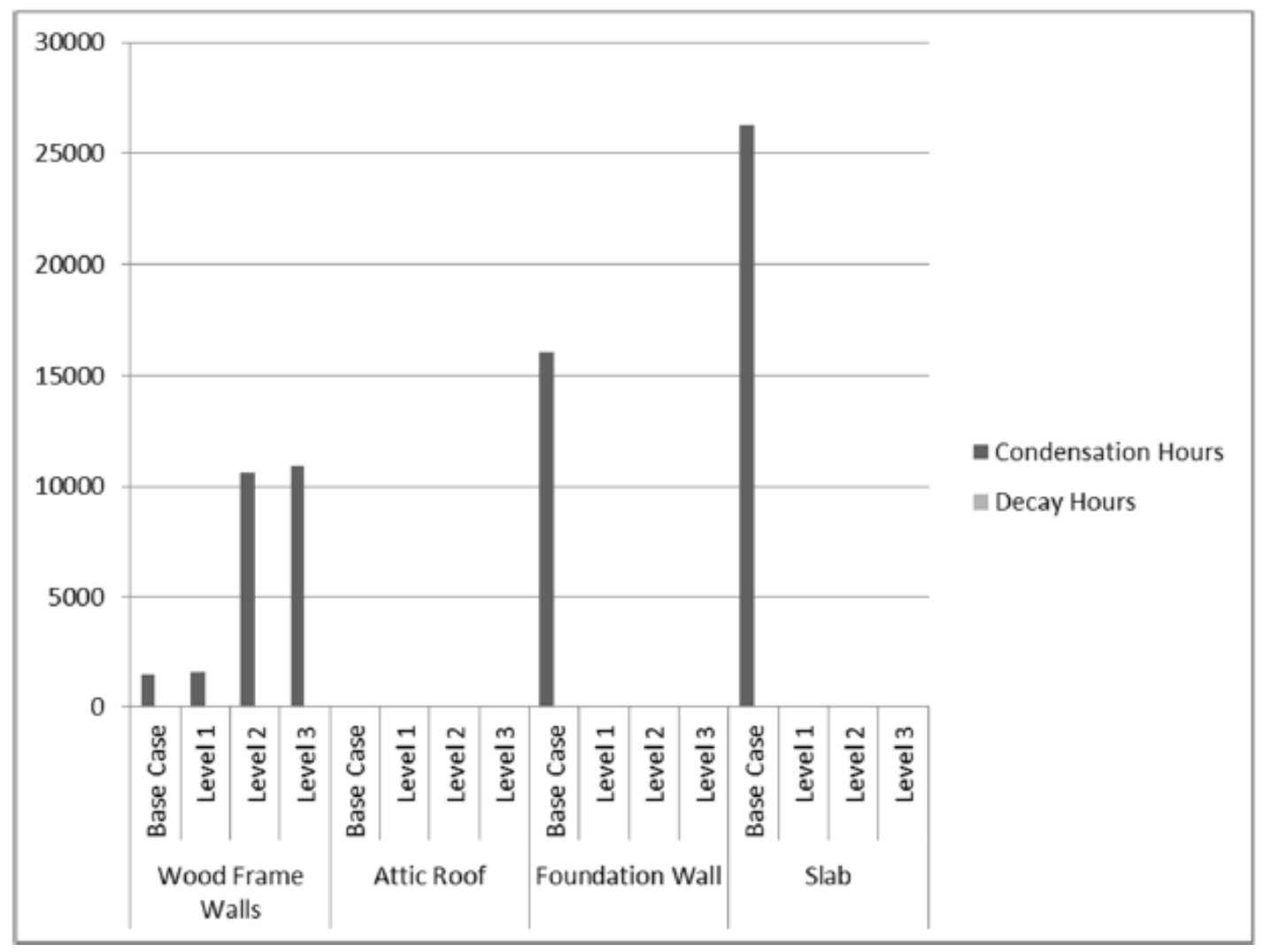

Condensation and Decay Hours in war time baseline and retrofit assemblies (Jermyn D., 2014) 


\section{Appendix I: Capital Cost Analysis}

1970s Single Detached Archetype

\begin{tabular}{|l|l|l|l|l|l|}
\hline $\begin{array}{l}1970 s \text { Single Detached } \\
\text { House }\end{array}$ & $\begin{array}{l}\text { Windows } \\
\left(\mathrm{m}^{2}\right)\end{array}$ & $\begin{array}{l}\text { Basement } \\
\left(\mathrm{m}^{2}\right)\end{array}$ & Slabs $\left(\mathrm{m}^{2}\right)$ & Walls $\left(\mathrm{m}^{2}\right)$ & Roof $\left(\mathrm{m}^{2}\right)$ \\
\hline Level 1 & 31.15 & 46.19 & 76.24 & 282 & 115.5 \\
\hline Level 2 & 31.15 & 46.19 & 76 & 282 & 115.5 \\
\hline Level 3 & 31.15 & 46.19 & 75.6 & 282 & 115.5 \\
\hline
\end{tabular}

\begin{tabular}{|l|l|l|l|l|l|l|l|l|}
\hline Unit Cost & Windows & Basement & Slabs & Walls & Roof & $\begin{array}{l}\text { Air } \\
\text { Sealing }\end{array}$ & Furnace & HRV/ERV \\
\hline Level 1 & $\$ 835.19$ & $\$ 74.94$ & $\$ 64.93$ & $\$ 97.23$ & $\$ 17.09$ & $\$ 1,182.00$ & $\$ 3,150.00$ & $\$ 2,125.00$ \\
\hline Level 2 & $\$ 927.63$ & $\$ 77.62$ & $\$ 68.75$ & $\$ 119.93$ & $\$ 19.48$ & $\$ 1,500.00$ & $\$ 3,665.00$ & $\$ 3,256.00$ \\
\hline Level 3 & $\$ 1,094.04$ & $\$ 79.70$ & $\$ 71.36$ & $\$ 128.28$ & $\$ 23.60$ & $\$ 1,500.00$ & $\$ 4,333.00$ & $\$ 3,726.00$ \\
\hline
\end{tabular}

\begin{tabular}{|l|l|l|l|l|l|l|l|l|}
\hline $\begin{array}{l}\text { Capital } \\
\text { Cost }\end{array}$ & Windows & Basement & Slabs & Walls & Roof & $\begin{array}{l}\text { Air } \\
\text { Sealing }\end{array}$ & Furnace & HRV/ERV \\
\hline Level 1 & $\$ 26,016.24$ & $\$ 3,461.31$ & $\$ 4,950.10$ & $\$ 27,418.28$ & $\$ 1,973.73$ & $\$ 1,182.00$ & $\$ 3,150.00$ & $\$ 2,125.00$ \\
\hline Level 2 & $\$ 28,895.62$ & $\$ 3,585.48$ & $\$ 5,225.00$ & $\$ 33,820.62$ & $\$ 2,250.47$ & $\$ 1,500.00$ & $\$ 3,665.00$ & $\$ 3,256.00$ \\
\hline Level 3 & $\$ 34,079.30$ & $\$ 3,681.28$ & $\$ 5,394.68$ & $\$ 36,175.46$ & $\$ 2,725.63$ & $\$ 1,500.00$ & $\$ 4,333.00$ & $\$ 3,726.00$ \\
\hline
\end{tabular}

\section{0s Semi-Detached Archetype}

\begin{tabular}{|l|l|l|l|l|l|}
\hline $\begin{array}{l}\text { 1970s Semi- } \\
\text { detached House }\end{array}$ & $\begin{array}{l}\text { Windows } \\
\left(\mathrm{m}^{2}\right)\end{array}$ & Basement $\left(\mathrm{m}^{2}\right)$ & Slabs $\left(\mathrm{m}^{2}\right)$ & Walls $\left(\mathrm{m}^{2}\right)$ & Roofs $\left(\mathrm{m}^{2}\right)$ \\
\hline Level 1 & 28.88 & 38.11 & 55.72 & 211 & 81.74 \\
\hline Level 2 & 28.88 & 38.11 & 55.42 & 211 & 81.74 \\
\hline Level 3 & 28.88 & 38.11 & 55.13 & 211 & 81.74 \\
\hline
\end{tabular}

\begin{tabular}{|l|l|l|l|l|l|l|l|l|}
\hline Unit Cost & Windows & Basement & Slabs & Walls & Roof & $\begin{array}{l}\text { Air } \\
\text { Sealing }\end{array}$ & Furnace & HRV/ERV \\
\hline Level 1 & $\$ 835.19$ & $\$ 74.94$ & $\$ 64.93$ & $\$ 97.23$ & $\$ 17.09$ & $\$ 1,182.00$ & $\$ 3,150.00$ & $\$ 2,125.00$ \\
\hline Level 2 & $\$ 927.63$ & $\$ 77.62$ & $\$ 68.75$ & $\$ 119.93$ & $\$ 19.48$ & $\$ 1,500.00$ & $\$ 3,665.00$ & $\$ 3,256.00$ \\
\hline Level 3 & $\$ 1,094.04$ & $\$ 79.70$ & $\$ 71.36$ & $\$ 128.28$ & $\$ 23.60$ & $\$ 1,500.00$ & $\$ 4,333.00$ & $\$ 3,726.00$ \\
\hline
\end{tabular}

\begin{tabular}{|l|l|l|l|l|l|l|l|l|}
\hline $\begin{array}{l}\text { Capital } \\
\text { Cost }\end{array}$ & Windows & Basement & Slabs & Walls & Roof & $\begin{array}{l}\text { Air } \\
\text { Sealing }\end{array}$ & Furnace & HRV/ERV \\
\hline Level 1 & $\$ 24,120.35$ & $\$ 2,855.82$ & $\$ 3,617.78$ & $\$ 20,515.10$ & $\$ 1,396.82$ & $\$ 1,182.00$ & $\$ 3,150.00$ & $\$ 2,125.00$ \\
\hline Level 2 & $\$ 26,789.90$ & $\$ 2,958.27$ & $\$ 3,810.13$ & $\$ 25,305.50$ & $\$ 1,592.67$ & $\$ 1,500.00$ & $\$ 3,665.00$ & $\$ 3,256.00$ \\
\hline Level 3 & $\$ 31,595.83$ & $\$ 3,037.32$ & $\$ 3,933.98$ & $\$ 27,067.46$ & $\$ 1,928.95$ & $\$ 1,500.00$ & $\$ 4,333.00$ & $\$ 3,726.00$ \\
\hline
\end{tabular}




\section{Bibliography}

- Bassett, E., \& Shandas, V. (2010). Innovation and climate action planning: perspectives from municipal plans. Journal of the American Planning Association, 76(4), 435-450.

- Blaszak, K. M. (2010). Towards sustainability: Prioritizing retrofit options for Toronto's single- family homes. Unpublished master dissertation, Ryerson University, Toronto, Canada. Available at:

http://digital.library.ryerson.ca/islandora/object/RULA\%3A1452

- Blaszak, K. M., \& Richman, R. (2013). Prioritizing Method for Retrofitting Toronto's Single-Family Housing Stock to Reduce Heating and Cooling Loads. Journal of Architectural Engineering, 19(4), 229-244.

- Canada Mortgage and Housing Corporation (2012), Energy Efficiency Building Envelope Retrofits, retrieved from http://www.cmhc-schl.gc.ca/odpub/pdf/67787.pdf

- Crawley, D., et al. (2004). EnergyPlus: New, capable, and linked. Journal of Architecture and Planning Research 21(4), 292 - 302.

- ecoENERGY (2010). ecoENERGY housing database. Natural Resources Canada, Ottawa

- Enbridge Gas Distribution Inc. (2014). Is your bill high? Retrieved Nov 26, 2015 from the Enbridge Gas Distribution Inc. Web site:

https://www.enbridgegas.com/homes/accounts-billing/is-your-bill-high.aspx

- EnergyPlus, 2013. EnergyPlus Input Output Reference.

- Flourentzou, F., \& Roulet, C. (2002). Elaboration of retrofit scenarios. Energy and Buildings, 34(2), 185-192.

- Foley, H. C. (2012). Challenges and opportunities in engineered retrofits of buildings for improved energy efficiency and habitability. AIChE Journal, 58(3), 658-677.

- Gowri, K., Winiarski, D., Jarnagin, R. (2009). Infiltration modeling guidelines for commercial building energy analysis. Retrieved October 17, 2015, from http://www.pnl.gov/main/publications/external/technical_reports/PNNL-18898.pdf

- Heritage Resources Centre (2009) Ontario Architectural Style Guide, The University of Waterloo, Ontario. Retrieved June 26, 2015 from https://uwaterloo.ca/heritage-resources-centre/sites/ca.heritage-resourcescentre/files/uploads/files/heritage_resources_centre_architectural_styles_guide_reduced .pdf

- Hubler, D., Tupper, K., Greensfelder, E. (2010). Pulling the levers on existing buildings: a simple method for calibrating hourly energy models. ASHRAE Transactions, 16(2), 2-8). 
- Hukka, A., \& Viitanen, H. A. (1999). A mathematical model of mould growth on wooden material. Wood Science and Technology, 33(6), 475-485.

- Hulchqnski, David (2007). The Three Cities Within Toronto: Income Polarization among Toronto's Neighbourhoods, 1970-2005, Research Bulletin 41, Cities Centre, University of Toronto

- Jermyn D. (2014) Deep energy retrofits: Toronto's urban single family housing stock Unpublished master dissertation, Ryerson University, Toronto, Canada.

- Johansson, P., Ekstrand-Tobin, A., Svensson, T., \& Bok, G. (2012) Laboratory study to determine the critical moisture level for mould growth on building materials. International Biodeterioration and Biodegradation, 73, 23-32.

- LBNL. (2014). Window. Retrieved April 2, 2014, from the Lawrence Berkeley National Laboratory Web site: http://windows.lbl.gov/software/window/window.html

- Lstiburek, J. (2002). Moisture control for buildings. ASHRAE Journal, 44(2), 36

- Maclean-Hunter. (1945) The housing plans of Canadians. Maclean-Hunter Publishing Company Limited, Toronto, ON.

- Mucciarone, A. (2011). Towards a proposed framework for analyzing sustainable renovation building envelope assemblies. Unpublished master dissertation, Ryerson University, Toronto, Canada.

- Natural Resources Canada - CanmetENERGY. (2009). The urban archetypes project: the city of Clarington. Retrieved on August 8, 2015 from: http://publications.gc.ca/collections/collection_2009/nrcan/M154-15-4-2009E.pdf

- National Renewable Energy Laboratory. (2014). Beopt. Retrieved Sep 19, 2015, from the National Renewable Energy Laboratory Web site: https://beopt.nrel.gov/

- Ontario Building Code (OBC). (2012). Ontario Ministry of Municipal Affairs and Housing, Building and Development Branch.

- Passive House Institute. (2012). Enerphit and enerphit+i. Retrieved March 10, 2015 from: http://www.passiv.de/downloads/03_enerphit_criteria_en.pdf

- Passive House Institute. (2013a). What is a passive house. Retrieved March 10, 2015 from: http://passipedia.passiv.de/passipedia_en/basics/what_is_a_passive_house

- Passivhaus (2011). EnerPHit Standard, Certification criteria for refurbished buildings http://www.passivhaus.org.uk/page.jsp?id=20

- Pitt, D., Randolph, J., St Jean, D., \& Chang, M. (2012). Estimating potential communitywide energy and greenhouse gas emissions savings from residential energy retrofits. Energy and Environment Research, 2(1), 44-61. 
- Qasass, R., Gorgolewski, M., Ge, H. (2014). Timber framing factors in Toronto residential house construction. Architectural Science Review, 57(3), 1-10.

- Raftery, P., Keane, M., O'Donnell, J. (2011). Calibrating whole building energy models: an evidence-based methodology. Energy and Buildings, 43(2011), 2356-2364.

- Rysanek, A. M., \& Choudhary, R. (2012). A decoupled whole-building simulation engine for rapid exhaustive search of low-carbon and low-energy building refurbishment options. Building and Environment, 50(0), 21-33.

- Smulski, S. (1999). Durability of energy-efficient wood-frame houses. Forest Products Journal, 49(5), 8-15.

- Statistics Canada (2011).http://www12.statcan.gc.ca/census-recensement/2011/assa/fogs-spg/Facts-csd-eng.cfm?LANG=Eng\&GK=CSD\&GC=3520005

- Straube, J. (2011). Building America special research project: high R-value enclosures for high performance residential buildings in all climate zones. Retrieved May 18, 2015, from http://www.buildingscience.com/documents/bareports/ba-1005-building-america-high-rvalue-high-performance-residential-buildings-all-climate-zones

- Straube, J., Grin, A. (2010). Building America special research project: high R roofs case study analysis. Retrieved May 18, 2015 from https://buildingscience.com/sites/default/files/migrate/pdf/BA-1006_BA_HighR_Roofs_Case_Study_Analysis.pdf

- The City of Toronto (2007). Energy Efficiency and Beyond: Toronto's Sustainable Energy Plan, retrieved on $31^{\text {st }}$ December,2014 from http://www.toronto.ca/legdocs/mmis/2007/pe/bgrd/backgroundfile-4989.pdf

- VandeWeghe, J. R., \& Kennedy, C. (2007). A spatial analysis of residential greenhouse gas emissions in the Toronto census metropolitan area. Journal of industrial ecology, 11(2), 133-144.

- Waier, P. R., Babbitt, C., Balboni, B., Charest, A. C. (2012). RS Means building construction cost data 2012. R. S. Means Company Incorporated.

- Weather data Depot, retrieved from http://www.weatherdatadepot.com/

- Yoon, J., Lee, E. J., Claridge, D. E. (2003). Calibration procedure for energy performance simulation of a commercial building. ASME Journal of Solar Energy, 125(3), 251-257.

- Zirnhelt, H. (2013). Using calibrated simulation to quantify the energy savings from residential passive solar design in canada. Unpublished master dissertation, Ryerson University, Toronto, Canada. 